Madrygal. Revista de Estudios Gallegos

ISSN: $1138-9664$

\title{
De illis de Mirapixe: Monio Fernandi. O trovador Múnio Fernandes de Mira- peixe e a sua parentela ${ }^{1}$
}

\author{
José António Souto Cabo ${ }^{2}$
}

Recibido: 27 de xullo de 2020 / Aceptado: 15 de outubro de 2020

Resumo. O trabalho revela a única atestação documental, até agora conhecida, em que surge explicitamente o nome de Múnio Fernandes de Mirapeixe, trovador integrado num dos mais antigos estratos da tradição manuscrita da lírica galego-portuguesa. Além de nos permitir fixar o nome do poeta como "Múnio" (e não "Nuno") e de confirmar a inclusão biográfica dele nas últimas décadas do séc. XII e primeiras do séc. XIII, esse registo abriu a porta para conhecer, pelo menos em parte, a identidade genealógica dos Mirapeixes, permitindo integrá-los no contexto familiar dos Monterrosos. A análise das informações relativas à esfera mais próxima do poeta foi complementada por um conjunto numeroso de dados sobre a estirpe de Monterroso, com destaque para o papel desta parentela na proteção do Caminho de Santiago (Hospital de Pena Godom) ou favorecendo a instalação da Ordem de Santiago no mosteiro familiar de Vilar de Donas. No concernente à obra poética de Múnio Fernandes, consideramos a possibilidade de lhe ser atribuída a cantiga de amor que aparece, em $B$, sob a autoria de Fernão Figueira de Lemos.

Palavras chave: linhagem de Monterroso; lírica galego-portuguesa; Múnio Fernandes de Mirapeixe; Ordem de Santiago; Sé de Lugo.

\section{[es] De illis de Mirapixe: Monio Fernandi. El trovador Múnio Fernandes de Mi- rapeixe y su parentela}

Resumen. La obra revela el único testimonio documental, hasta ahora conocido, en el que aparece explícitamente el nombre de Múnio Fernandes de Mirapeixe, trovador integrado en uno de los estratos más antiguos de la tradición manuscrita de la lírica gallego-portuguesa. Además de permitirnos fijar el nombre del poeta como "Múnio" (y no "Nuno") y confirmar su inclusión biográfica en las últimas décadas del s. XII y primeras del s. XIII, este registro abrió la puerta para descubrir, al menos en parte, la identidad genealógica de los Mirapeixes, permitiéndonos integrarlos en el contexto familiar de los Monterroso. El análisis de la información relacionada con el ámbito más cercano al poeta ha sido complementado con un numeroso conjunto de datos sobre la estirpe Monterroso, destacando el papel de este linaje en la protección del Camino de Santiago (Hospital de Pena Godom) o favoreciendo la instalación de la Orden de Santiago en el monasterio familiar de Vilar de Donas. En cuanto a la obra poética de Múnio Fernandes, consideramos la posibilidad de que le sea atribuida la canción de amor que aparece, en $B$, bajo la autoría de Fernão Figueira de Lemos.

Palabras clave: linaje de Monterroso; lírica gallego-portuguesa; Múnio Fernandes de Mirapeixe; Orden de Santiago; Catedral de Lugo.

\section{[en] De illis de Mirapixe: Monio Fernandi. The Troubadour Múnio Fernandes de Mirapeixe and his Family Members}

Abstract. This paper reveals the so far known only documentary testimony in which the name of Múnio Fernandes de Mirapeixe, a troubadour from one of the earliest periods in the Galician-Portuguese manuscript tradition, explicitly appears. Besides allowing us to establish the poet's name as "Múnio" (not "Nuno"), and to confirm that he lived in the last decades of the twelfth and thirteenth centuries, this record opens the door to discover, at least in part, the genealogical

1 Este artigo integra-se nos projetos: Stemma. Do canto à escrita. Produção material e percursos da lírica galego-portuguesa (PTDC/LLTEGL/30984/2017) e Voces, espacios y representaciones femeninas en la lírica gallego-portuguesa (PID2019-108910GB-C22). Agradecemos a colaboração que, por diversas vias, nos foi oferecida por Carla Amado, Miguel García-Fernandez, Santiago Jiménez Gómez, Ricardo Pichel e Yara Frateschi Vieira.

2 Universidade de Santiago de Compostela. Departamento de Filologia Galega.

Correio-e: joseantonio.souto.cabo@usc.es; https://orcid.org/0000-0002-4779-8115. 
identity of the Mirapeixes, allowing us to integrate them into the Monterrosos' family context. The analysis of the information related to the area closest to the poet is complemented with a large set of data on the Monterroso lineage, highlighting the role of this lineage in protecting the Camino de Santiago (Hospital de Pena Godom) or favoring the installation of the Order of Santiago in the family monastery of Vilar de Donas. Furthermore, with regard to Múnio Fernandes' poetic work, we consider the possibility that the love song attributed in $B$ to Fernão Figueira de Lemos may in fact be accredited to him.

Keywords: Monterroso Lineage; Galician-Portuguese Lyric; Múnio Fernandes de Mirapeixe; Order of Santiago; Lugo Cathedral.

Sumário. 1. In domo que stat in Cruce. 2. Ego, domna Gontrode Ruderici, abbatissa. 3. De illis de Mirapixe. 4. Arie Petri de Monterroso. 5. Unum quinionem de Petro Odoarii. 6. Monio Fernandiz de Mirapeyxe. 7. Conclusão e esquema genealógico. 8. Apêndice documental. 9. Referências bibliográficas.

Referência normalizada: Souto Cabo, J. A. (2020): “De illis de Mirapixe: Monio Fernandi. O trovador Múnio Fernandes de Mirapeixe e a sua parentela”, em Madrygal. Revista de Estudios Gallegos 23, pp. 335-373.

Angelo Colocci manifestou alguma incerteza na hora de transcrever o nome próprio do trovador da linhagem dos Mirapeixe que é objeto deste estudo. Com efeito, quer na Tavola Colocciana, quer na rubrica atributiva que precede as suas cantigas em $B$, a forma inicial Monio é seguida do esclarecimento "vel Nuno (Fernandez de Mirapeyxe)". Visto que, em princípio, não existem motivos de natureza paleográfica dos quais resulte, necessariamente, a equivalência das lições "Monio" e "Nuno", estamos em crer que o humanista italiano pretendia, com esse esclarecimento, assinalar uma alternativa para resolver as dúvidas que, pela sua raridade, (lhe) gerava o primeiro dos resultados ${ }^{3}$.

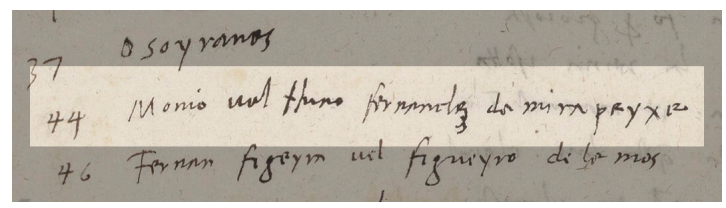

Tavola Colocciana (fl. 300v)

Trata-se, com efeito, de um antropónimo de ocorrência única no elenco dos poetas da lírica galego-portuguesa; pelo contrário, são relativamente frequentes os autores nomeados "Nuno" (Nuno Eanes Cerzeo, Nuno Fernandez Torneol, Nuno Perez Sandeu, Nuno Porco, Nuno Rodrigues de Canderei, Nuno Treez), mas em nenhum dos casos se manifesta qualquer tipo de hesitação interpretativa. Pensamos, portanto, que o nome próprio do nosso trovador foi, em versão atualizada, "Múnio"4 . Como veremos, essa última forma é a que nos transmite a única escritura em que aparece claramente o nome do poeta, associado a outros três irmãos.

Face à escassez de informações históricas diretas sobre o compositor em questão, já contávamos com atestações seguras doutros Fernandes de Mirapeixe, estirpe cujo apelido linhagístico remete para uma área no noroeste do concelho de Outeiro de Rei ${ }^{5}, 10 \mathrm{~km}$ a norte da cidade de Lugo ${ }^{6}$. Em concreto, era conhecida a existência de quatro irmãos do poeta: Rodrigo, Gonçalo, Garcia e Teresa.

Neste trabalho, somamos mais dois com o (mesmo) nome de "Pedro" e identificamos, pela primeira vez, o trovador no registo documental com cuja análise preliminar encetamos este trabalho. As alíneas posteriores serão dedicadas a aprofundar, tanto quanto foi possível, no conhecimento de personagens ou parentelas

3 A incerteza sobre a denominação do trovador só se repete -e do mesmo modo- no poeta que se lhe segue em $B$ : "Fernan Figeyra vel Figueyro de Lemos".

4 É habitual que apareça nomeado como "Nuno", apesar de Carolina Michaëlis ter utilizado a forma "Monio Fernandes, de Mirapeixe", mas com esta indicação: "Seria importante provar que realmente se chamava Monio (Muño = Nuño, Nuno)" (Michaëlis de Vasconcelos 1904: 526-527).

5 Na atualidade, "Mirapeixe" é a denominação de um paço na freguesia lucense de Santa Marinha de Outeiro de Rei, mas na Idade Média o topónimo deverá ter definido uma área geográfica no território de Gaioso. Numa escritura de 1369 as freiras de Santa Maria-a-Nova entregavam a Lopo Afonso de Goiôs: "toda quanta herdade et voz et casas et arvores et formaes nós avemos et nos pertẽesce en Mirapeyxe, sub segnos de Santiago de Goyos et de Santiago de Francos" (AHN, Santa Maria-a-Nova de Lugo, 1124, n 20). Como vemos, a terra de Mirapeixe é identificada com um espaço que abrange as freguesias de Santiago de Gaioso e Santiago de Francos, integradas naquele mesmo concelho, o que parece ser confirmado no testamento de Teresa Fernandes de Mirapeixe (cf. infra). Madoz (1849: 260) situa na Ponte de Rábade, à beira do rio Minho, "los restos del ant. solar llamado Mirapeixe, de donde procedieron los caballeros de la edad media, que llevaron en aquel pais el apellido de Galloso".

6 Uma indicação imprecisa de Michaëlis de Vasconcelos (1904: 526) sobre a existência de uma terra em Catalunha denominada Miralpeix (conc. Tiurana, Lleida) fez com que, durante algum tempo, se tenha considerado a possibilidade de ser catalão (Tavani 1990: 308). Topónimos similares reaparecem noutros pontos de Catalunha e ainda em Aragão, Navarra ou Occitânia. Neste último território, encontramos Mirapeis / Mirepoix, localidade que deu origem à linhagem a que pertenceu o trovador cátaro Peire Rogier de Mirepoix. 
nele referidas. Na última secção, o centro de interesse será a figura histórica do trovador, incluindo algumas questões relacionadas com as características e volume da obra poética. $\mathrm{O}$ trabalho complementa-se com um esquema genealógico e com a edição, em apêndice, daqueles textos (éditos ou inéditos) que se julgaram mais relevantes ${ }^{7}$.

\section{In domo que stat in Cruce}

Por enquanto, só conseguimos registar Múnio Fernandes (de Mirapeixe) na Notícia da casa da Cruz, escrito de natureza probatória / informativa em que se arrolam os indivíduos por intermédio dos quais a Sé de Lugo ganhou a posse de uma casa sita na Cruz [D.19 $]^{8}$. Além daquilo que concerne de modo particular ao poeta, o conteúdo desse texto encerra um excecional interesse por ser a chave para desvendar, em parte, as origens dos Mirapeixes, já que todos os indivíduos citados deverão ter pertencido à mesma estirpe ${ }^{9}$ :

Isti sunt quiniones quos habet Lucensis Ecclesia in duas quintas que fuerunt Arie Petri in domo que stat in Cruce: primo de decano Johan Arie, et secundo de Petro Arie, tercio de Didaco Arie, quarto de Johan Arie de Archos, quinto de Fernando Arie de Villanova, sexto de Johan Arie de Monte Roso, septimo de Ruderico Arie. De quinta que fuit de domna Marina Petri, habet Sedes Lucensis mediam; scilicet: unum quinionem de Petro Odoarii et altero de Marina Odoarii. Et quinta integra quam habet de domna Urraca Gunzalvi. Et de altera quinta que fuit de miona domna Urraca de Igian, habet inde quartam de domna Eldoncia de Bacorin, et alteram quartam habet de domna Guntrode, que fuit abbatissa de Igian, et alteram quartam de illis de Mirapixe, scilicet: de Petro Fernandi, et Ruderico Fernandi, et de Monio Fernandi, et de Gunzalvo Fernandi. Et de quarta de quinta que fuit de domna Toda Ruderici, habet inde Sedes unum quinionem, quod dedit Marina Pelagiiz et altero quinione de domna Toda Pelagii [...].

As referências pessoais situam-se em dois planos; por um lado, comparecem os antigos donos do imóvel e, por outro, aqueles que os

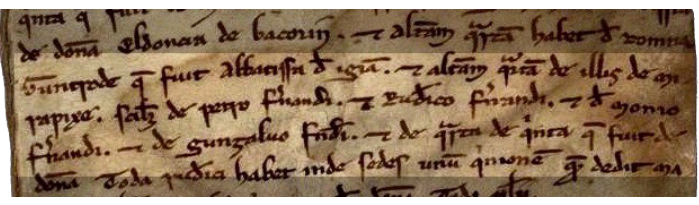

AHN, Cat. de Lugo, maço $1331 \mathrm{H}, \mathrm{n}^{\circ} 24$

sucederam nas posses proporcionais respetivas e que as vieram a entregar à Sé de Lugo ${ }^{9}$. No primeiro nível encontramos os nomes de Airas Peres, Marina Peres (cf. infra), Urraca Gonçalves e a miona Urraca de Giám. Como vemos, os quatro irmãos Fernandes de Mirapeixe -Pedro, Rodrigo, Múnio e Gonçalo- surgem por ter sido coproprietários de um quarto da quinta parte daquele imóvel que pertencera a esta última: "de altera quinta que fuit de miona domna Urraca de Igian [...] alteram quartam de illis de Mirapixe, scilicet: de Petro Fernandi, et Ruderico Fernandi, et de Monio Fernandi et de Gunzalvo Fernandi".

O quinhão (1/5) que coubera à miona tinha sido, por sua vez, dividido em quatro partes de que foram proprietários: Aldonça (Rodrigues) de Bacurim, Gontrode (Rodrigues), os irmãos Mirapeixe e uma Toda Rodrigues cuja porção fora ainda repartida entre Marina Pais e Toda Pais. Segundo se declara na própria escritura, Gontrode (Rodrigues) fora abadessa de Giám: "domna Guntrode, que fuit abbatissa de Igian"10. Trata-se de uma personagem cujo vínculo -tia- com alguns dos Mirapeixes já era conhecido, pois no testamento da abadessa são citados dois sobrinhos também presentes no documento em análise: Rodrigo e Gonçalo Fernandes (cf. infra).

Aldonça de Bacurim -abadessa ou freira do antigo mosteiro dessa freguesia do atual concelho de Lugo - foi irmã de Gontrode, pois sabemos que o patronímico dela era "Rodrigues"12. No Livro (ou Memorial) de Aniversários da Sé de Lugo ${ }^{13}$ - cit. $L A$ - consta que o seu óbito se produziu a 17 de abril de 1201 e que

Esses escritos são identificados pelo número de ordem precedido da sigla $\mathrm{D}$ entre parênteses retos.

A rua da Cruz aparece historicamente vinculada à Sé de Lugo. Veja-se Portela Silva e García Oro 1997: 113.

As questões cronológicas relativas ao ato jurídico de cessão do imóvel que subjaz ao texto são analisadas na última alínea deste artigo.

10 Essa distinção não se dá no caso de Urraca Gonçalves. Por outro lado, na referência à parte de Marina Peres, supomos que cada quinhão dos dois filhos representa uma mediam do total da mãe e não, em conjunto, só metade do que correspondia a essa dama, como poderia sugerir a leitura do texto.

11 Ele situava-se no local que ainda hoje recebe o nome de "Mosteiro", na margem direita do Minho. Sobre alguns aspetos genéricos, veja-se Pérez Rodríguez 2019: 221, 268, 1143-1144 (cf. infra).

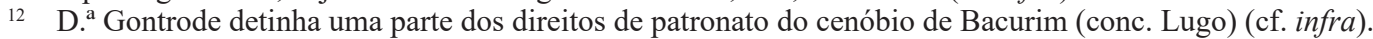

13 Utilizamos uma denominação singular, mas trata-se de três códices diferentes custodiados no AHN e identificados com as cotas L.1040, L.1041 e L.1042. Segundo foi verificado, além do dia em que a pessoa faleceu, podem conter 
deixou aos cónegos lucenses a "bonam servicialiam" que tinha em S. Pedro de Navalhos (conc. Guntim) ${ }^{14}$. Juan Pallares Gaioso (1700: 383) cita, com alguns enganos, a existência de um documento do arquivo da Sé de Lugo que conservava a memória da doação a essa instituição de dois terços do mosteiro de Bacurim feita pelas freiras irmãs Aldonça e Gontrode Rodrigues e pelo sobrinho Pedro (I) Fernandes de Mirapeixe (cf. infra). Por sua vez, Toda Rodrigues deverá ter sido irmã de Aldonça e Gontrode, portanto, tia dos Fernandes de Mirapeixe e mãe de Marina ${ }^{15}$ e Toda Pais ${ }^{16}$.

A respeito de Urraca de Giám, a qualificação de miona $^{17}$ que recebe sugere que foi domina ${ }^{18}$ do mosteiro situado na freguesia homónima do concelho lucense de Taboada - no condado de

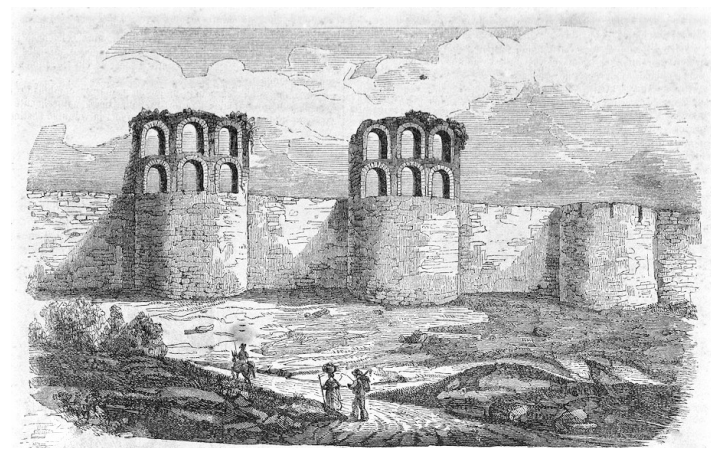

Muralhas de Lugo em gravura de 1850 (Semanario Pintoresco Español)
Monterroso e antiga terra de Ínsua-, o que a relaciona diretamente com Gontrode Rodrigues, abadessa dessa mesma instituição (cf. infra). Por outro lado, atendendo ao parentesco entre Gontrode e os Mirapeixes, é lógico pensarmos que essa Urraca esteve ligada por laços familiares a todos eles, o que nos conduz a pensar numa transferência hereditária. Apesar de não termos informação explícita sobre a natureza desse vínculo, a hipótese mais plausível é que tenha sido mãe de Gontrode, Aldonça e Toda; portanto, avó dos Mirapeixes citados (e, por outro lado, de Marina e Toda Pais). O facto de não ser referido o progenitor por intermédio do qual Múnio Fernandes e os irmãos teriam herdado o bem em questão sugere que já falecera na altura em que se produziu a sucessão hereditária. Como veremos, Gontrode teve uma irmã de nome Lupa (Rodrigues), falecida provavelmente em 1192, que poderá ter sido a mãe dos quatro Fernandes de Mirapeixe referidos no documento.

Entre os antigos possuidores da casa na Cruz surgia em primeiro lugar o nome de Airas Peres, talvez porque ele detivera $2 / 5$ do imóvel ("duas quintas que fuerunt Arie Petri"), face a proporções menores com que contaram as três mulheres restantes: Marina Peres, Urraca Gonçalves e Urraca de Giám. A documentação evidencia que Airas Peres e Marina Peres foram filhos de Pedro Eanes de Monterroso, o

indicação sobre a data concreta em que se produziu o óbito ou sobre aquela em que o aniversário foi instituído por outra pessoa. Assim, o bispo D. Miguel estabelece o pagamento do aniversário no seu testamento lavrado em 1267.04.28 (AHN, Cat. de Lugo, 1330D, $\mathrm{n}^{\circ}$ 19bis), mas a datação em $L A$ corresponde ao dia da morte dele em 1270.05.16 (AHN L.1041, fl. 3r; Jiménez Gómez 1987: 186). O conteúdo das diferentes alíneas terá sido elaborado na Sé -em modo mais ou menos fidedigno- a partir da fonte documental primária.

14 "XV kalendas maii, era $\mathrm{M}^{\mathrm{a}} \mathrm{CC}^{\mathrm{a}} \mathrm{XXX} \mathrm{XX}^{\mathrm{a}} \mathrm{I}$. Ego Eldonzia Ruderici de Bacorin do lucensis canonicis pro aniversario meo unam bonam servicialiam quam habeo in Lavalos, sub aula Sancti Petri, cum omnibus pertinenciis suis" (AHN, L.1040, fl. 29v; Jiménez Gómez 1987: 180).

15 Podemos identificar esta última com a "domina Marina Pelagii" - mulher de Viviano Fernandes- que registamos, entre 1175 e 1213, por ocasião de duas transações patrimoniais com a Ordem do Hospital (García Tato 2004: $\mathrm{n}^{\circ}$ 24, 58). Por esses escritos, sabemos que ela tinha propriedades nas terras de Lemos, Páramo, Paradela, Sardinheira (conc. Savinhao) e Sárria, e que recebeu da Ordem a bailia de Gundrame (conc. Paradela) e S. Cipriano com o casal de Cendoi (Adai, conc. Paradela?).

16 O cavaleiro Rodrigo Eanes de Bacurim diz ser filho de uma "domna Toda" a que pertenceram vários casais próximos da igreja de Bacurim ("totius casalis de «Domna Toda» vocati”) e direitos de patronato nessa igreja (AHN, Cat. de Lugo, 1330A, n 17 [1261]). O relacionamento com a paróquia de Bacurim, a que aparecem associadas Gontrode e Aldonça Rodrigues, sugere a possibilidade de se tratar de Toda Pais, uma das duas filhas de Toda Rodrigues.

17 O termo remonta ao latim MEA DOMNA. Viterbo (1865, s. v. Meana, e Miana ou Miona) indica: "Dava-se este honroso tratamento no século XII, e XIII às senhoras de mais idade, ou viúvas de primeira qualidade, e nobreza". Veja-se também Maia 1984. Note-se que não lhe é atribuído, como a Gontrode, o título de abbatissa.

18 Em princípio, a domina -amiúde viúva- era patrona e regedora do mosteiro, o que não exclui a sua profissão nele como religiosa, eventualmente abadessa. Sobre o tema, vejam-se, entre outros, García de Cortázar 2004: 226-231 e Cavero Domínguez 2014. A respeito dessa figura, o primeiro aponta: "Se trata de la centralización de la tutela del cenobio familiar en manos de una sola persona, de un dominus. En principio, este papel se reserva a uno de los miembros de la familia que haya elegido la vida religiosa. Después, en el caso de que nadie haya seguido ese camino, se faculta al abad para escoger como dominus [ou domina] a uno de los herederos o diviseros" (García de Cortázar 2004: 230). 
que nos leva a pensar que Urraca (Peres) de Giám também formava parte da progénie deste último ${ }^{19}$. A favor desta última hipótese depõe a muito expressiva convergência de interesses que, a múltiplos níveis, observamos entre Gontrode Rodrigues e os filhos de Airas Peres de Monterroso, como se evidencia ao longo das páginas deste trabalho.

De acordo com o exposto, Pedro Eanes de Monterroso terá sido bisavô por linha materna dos Fernandes de Mirapeixe. Trata-se de um cavaleiro da corte de Afonso VII, na qual se encontra documentado (ao menos) entre 1135 e $1137^{20}$. Ele testemunha dois documentos régios de maio e dezembro de 1135 (Recuero Astray 1998, no 54, 61). No segundo, o seu nome encontra-se num conjunto em que também registamos os de Fernando Oares -que o precede-, Airas Calvo e Pedro Bazaco (cf. infra $)^{21}$. Posteriormente, em 1137, ele integra o grupo de testemunhas do diploma outorgado por Afonso VII em Toledo pelo qual o monarca entregava e acoutava uma área territorial ao mosteiro de Osseira (Romaní Martínez 1989, $\left.\mathrm{n}^{\mathrm{o}} 15\right)^{22}$. São escassos os dados diretos relativos à implantação patrimonial de Pedro Eanes, só sabemos, por uma referência retrospetiva, que entregara à Sé de Lugo um casal em Lodeiro na freguesia de Lestedo (conc. Palas de Rei), numa zona situada entre Vilar de Donas e a povoação de Palas de Rei: "hereditatem nostram de Lodeiro, quam lucensi ecclesie donus Petrus Johannis de Monte Roso dedit pro anima sua cum omnibus pertinenciis suis" ${ }^{23}$.
Como veremos, encontramo-nos numa das áreas preferenciais para esta estirpe e onde se localizava precisamente o mosteiro familiar da mesma: S. Salvador de Vilar de Donas ${ }^{24}$. Pedro Eanes esteve casado com uma Aldonça, de origens desconhecidas ${ }^{25}$, que supomos foi mãe de Airas Peres, de Marina Peres e de Urraca (Peres) de Giám (cf. infra) ${ }^{26}$.

Nas páginas que se seguem, exporemos os dados documentais com que contamos sobre esses três irmãos e/ou sobre os seus descendentes, a começar pelo relativo a Gontrode Rodrigues, a filha mais bem conhecida da miona de Giám. Esta alínea irá, assim, seguida por outras correspondentes aos Mirapeixes, a Airas Peres de Monterroso e aos filhos, e a Pedro Oares. Como foi dito, na última secção retomaremos a figura do trovador Múnio Fernandes de Mirapeixe.

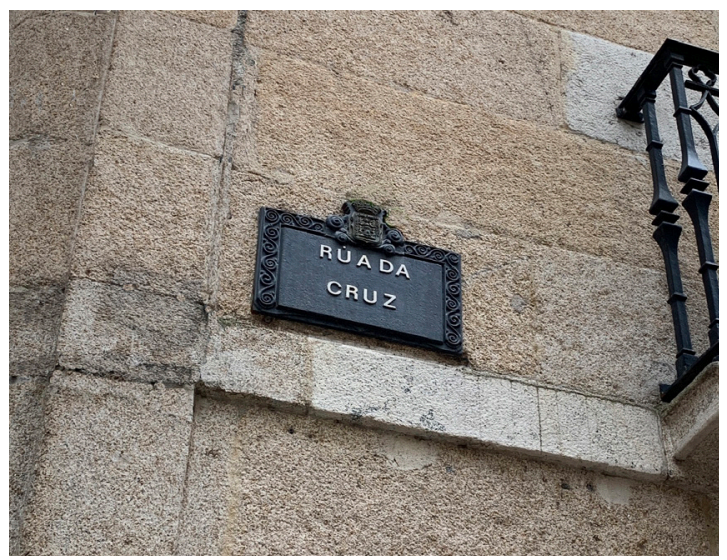

Rua da Cruz (Lugo)

19 A informação sobre o parentesco que unia Pedro Eanes a Airas e Marina Peres, bem como o nome da esposa daquele e mãe destes últimos, surge em documentos relativos a Pedro Oares e Rodrigo Fernandes -respetivamente, neto e bisneto desse cavaleiro-, aos quais faremos referência posteriormente (AHN, L.1041, fl. 31v; AHN, Cat. de Lugo, 1326A, $n^{\circ} 13$ ). Não temos dados que nos permitam definir claramente o vínculo de "domna Urraca Gunzalvi" com o resto dos citados, mas aventamos a possibilidade de ela ter sido neta, por via materna, de Pedro Eanes. Numa escritura de 1229, refere-se uma mulher desse nome a que pertenceram uma casa e uma cortinha perto da Sé: "in Lucense civitate prope circum Beate Marie, inter casam et cortinam que fuit Urrace Gundissalvi” (AHN, Cat. de Lugo, 1327C, $\left.\mathrm{n}^{\circ} 24\right)$.

20 Não podemos descartar que ele tenha sido conhecido, anteriormente, como "Pedro Eanes de Porto Marim" (Recuero Astray 1998, nº 15 [1125]). Também pode ser identificado com o personagem homónimo, sem apostila toponímica, que ratifica documentos da rainha Urraca (Recuero Astray 2002, nº 54 [1121], 57 [1123]).

21 Sobre estes últimos, veja-se Souto Cabo 2012: 90-96, 132-133.

22 No inquérito elaborado para dirimir o contencioso sobre a titularidade do vilar de Couso, Rodrigo Airas, um dos netos de Pedro Eanes, declara ter ouvido manifestações do pai e do avô a respeito desse pleito (cf. infra). De acordo com o que sabemos sobre Rodrigo Airas e os irmãos, isso só terá sido possível se o percurso biográfico de Pedro Eanes se prolongou, no mínimo, até meados da década de sessenta do séc. XII.

23 AHN, Cat. de Lugo, 1326D, no 17 [1203]. Naquela mesma freguesia, no lugar de Portos, parece ter existido um hospital para peregrinos dependente de Vilar de Donas (Novo Cazón 2008: 104).

24 Sobre os diversos aspetos envolvidos na história desta instituição, veja-se o estudo introdutório à edição da coleção documental por Novo Cazón 1986.

25 Aldonça Rodrigues de Bacurim recebeu, portanto, o nome dessa avó.

26 Também de quem, supomos, foi mãe de Urraca Gonçalves, cuja identidade nos é desconehcida. 


\section{Ego, domna Gontrode Ruderici, abbatissa}

No testamento de D. ${ }^{a}$ Gontrode [D.3], tia do poeta, lavrado em janeiro de 1211, ela figura como abatissa, mas não se especifica a instituição conventual que chegou a presidir. Contudo, como foi já notado, sabemos que se tratava de Santa Maria de Giám, instituição certamente fundada pelos Monterrosos, portanto mosteiro familiar, como se deduz da presença continuada de mulheres dessa linhagem como regedoras ou abadessas do mesmo. De facto, aos nomes de Urraca de Giám e de Gontrode, te(re)mos de somar os das abadessas Urraca Airas de Monterroso e Urraca Dias, filha e neta, respetivamene, de Airas Peres de Monterroso (cf. infra $)^{27}$. Pensamos que Giám terá suposto a continuidade para a vida monástica feminina de Vilar de Donas, quando este último mosteiro, também fundação patrimonial dos Monterrosos, foi entregue à Ordem de Santiago ${ }^{28}$.

Pelo escrito em questão vimos a conhecer o importante conjunto de bens de que dispôs a religiosa, e que aparecem situados em Berlai (Pinheiras, conc. Guntim) ${ }^{29}$, Giám (conc. Taboada), Lugo, Montouto (Sirviám, conc. Guntim), Palas de Rei, Paços (Recelhe, conc. Portomarim), Portomarim, Toiriz (S. Salvador de Ínsua, conc. Taboada) ${ }^{30}$, Varaçom (conc. Santisso), Vilarvassim (conc. Portomarim). Refere ainda os direitos que tinha nos mosteiros de São Miguel de Bacurim (conc. Lugo) e Santa Maria de Ínsua (conc. Taboada) ${ }^{31}$, e nas igrejas de S. Pedro de Mera (conc. Lugo) e Santiago de Linhares (conc. Santisso) ${ }^{32}$. A abadessa menciona ainda, de modo genérico, o que lhe correspondia na terra de Montenegro, antiga demarcação cujo extremo meridional chegava à terra de Mirapeixe ou Gaioso ${ }^{33}$.
Os beneficiários são, por um lado, o mosteiro que regia, o de Vilar de Donas (conc. Palas de Rei), o Cabido da Sé de Lugo e, por outro, Rodrigo Fernandes de Mirapeixe e o irmão Gonçalo Fernandes. A testadora só refere o nome de uma irmã, Lupa, pelos vínculos e negócios patrimoniais que manteve com ela, embora não se encontre entre os beneficiários da manda, talvez porque nessa altura já falecera (cf. infra).

Temos conhecimento de que Gontrode Rodrigues morreu a 3 de fevereiro de 1212 , segundo consta no $L A$ :

III $^{\mathrm{o}}$ nonas februarii [...]. Era $\mathrm{M}^{\mathrm{a}} \cdot \mathrm{CC}^{\mathrm{a}} \cdot \mathrm{L}^{\mathrm{a}}$. Ego Guntrode Ruderici assigno lucensis canonicis XII solidos pro aniversario meo per domos meas quas habeo in Lucense civitate et in Portu Marin. Et teneat eas sobrinus meus Rudericus Fernandi de Mirapisce et si defecerit ipse vel proienes eius in solutione predictorum denariorum canonicis recipiant libere domos ipsas. Hic recipiant canonici denarios de agro grano ${ }^{34}$.

Como vemos, neste caso, é desvendado o vínculo familiar que a unia a Rodrigo Fernandes: "sobrinus meus Rudericus Fernandi de Mirapisce" -o que não consta na manda. Ele recebe, em ambas as fontes, o encargo de pagar doze soldos aos cónegos lucenses no aniversário da morte dela, ganhando, em compensação, o usufruto do que pertencia à abadessa nas moradas de Portomarim e de Lugo. Também lhe deixa um casal na vila de Montouto (Sirviám, conc. Guntim) e, partilhados com o irmão Gonçalo, dois em Varaçom (conc. Santisso) bem como a "voz" da abadessa na terra de Montenegro $^{35}$. As posses citadas, de modo explícito, inserem-se maioritariamente nas terras

27 Se excetuarmos o testamento de Gontrode Rodrigues, só conservamos (ou temos notícia de) três escrituras relativas a esse mosteiro. Duas pertencem ao núcleo documental de Vilar de Donas (Novo Cazón 1986: nº 31 e 203) e outra ao da Sé de Lugo (AHN, Cat. de Lugo, 1328C, nº 6 [1245]) (cf. infra).

28 A integração da manda de D. ${ }^{a}$ Gontrode no cartório de Vilar de Donas leva a pensar que o mosteiro santiaguista herdou os bens de Giám após a extinção deste último, talvez já na segunda metade do séc. XIII.

29 A forma finda em consoante nasal ("Berlan") do manuscrito está hoje representada por uma em ditongo decrescente. Essa mesma alternância histórica reaparece noutros topónimos da zona: Candan $>$ Candai, Ferron $>$ Ferroi, Fingon > Fingoi, Mazon > Mazoi, Orvezan > Orvazai, Saaman > Samai etc. O topónimo "Berlám" existe na freguesia de Monte Cubeiro (conc. Castro Verde), mas fica afastado das restantes propriedades.

30 É a localização mais próxima do mosteiro de Giám, beneficiário pela propriedade ali situada. Entre outros locais, o topónimo repete-se em Piúgos (conc. Lugo).

31 Supomos que se trata de um mosteiro, hoje desaparecido, no arciprestado de Ínsua - demarcação identificável com o nordeste do atual concelho de Taboada, no qual se integra a freguesia de Giám.

32 Trata-se do sistema de igrejas próprias “que pueden ser vendidas, donadas, heredadas y repartidas” (D’Emilio 1996: 68-69) (cf. infra).

33 É provável que o limite meridional, nessa zona, fosse a área em que o rio Ladra desemboca no Minho.

34 AHN, L.1040, fl. 11r; Jiménez Gómez 1987: 169.

35 Isto é, os direitos de propriedade ou de padroado que detinha naquele antigo condado. 
de Aveancos, Mera, Monterroso, Palhares e Portomarim $^{36}$. Elas podem ser situadas, grosso modo, no percurso do Caminho de Santiago entre os rios Minho e Furelos. Em três povoações, Lugo, Palas de Rei e Portomarim, referem-se moradias pertencentes a Gontrode Rodrigues: "domibus que sunt in Luco, in rua Nova"37, "porcionem domus de Palaz de Rey"; "casa de Portumarino", "domibus de Portumarino"38.

O diploma, apesar de ser fonte notável de dados, deixa em aberto múltiplas questões essenciais sobre a família dos Fernandes de Mirapeixe. Assim, por exemplo, não revela de modo explícito a identidade do irmão ou irmã de Gontrode de quem foram filhos Rodrigo e Gonçalo e, por outro lado, também não oferece informação explícita sobre os antecedentes familiares da própria titular. Quanto ao primeiro aspeto, à vista dos elementos de que dispomos, consideramos que poderá tratar-se de Lupa (Rodrigues), a irmã citada no testamento da abadessa: "sorore mea domna Lupa". Ela é identificável com a personagem homónima, falecida em 22 de janeiro de 1192, que entregou à Sé de Lugo uma casa e parte de uma cortinha na cidade de Lugo próxima do Carvalhal:

$\mathrm{XI}^{\circ}$ kalendas februarii, era $\mathrm{M}^{\mathrm{a}}$.CC ${ }^{\mathrm{a}} \cdot \mathrm{XXX}^{\mathrm{a}}$. Anniversarium Lupe Ruderici fiat sequenti die post $\mathrm{LXX}^{\mathrm{a}}$, que pro anniversario suo assignavit lucensis canonicis $\mathrm{V}^{\mathrm{e}}$ solidos per domum et per medietatem cortine que est in viculo qui discurrit a Carvaliali ex transverso iuxta domos monasterii de Meira ${ }^{39}$.

Ora bem, se a considerarmos mãe dos cavaleiros citados no testamento de Gontrode Rodrigues
- e ainda doutros dois ausentes: Múnio e Pedro (I)- será necessário pensar, por motivos cronológicos, que não foi a progenitora de todos os "Fernandes de Mirapeixe" (cf. infra).

Como vimos, a abadessa de Giám deixou em herança ao sobrinho Rodrigo Fernandes de Mirapeixe, de modo privativo, um casal em Montouto ("casalem de Montouto"), topónimo que remete para a antiga freguesia de Santo Adriano de Montouto, hoje integrada na de Sirviám (conc. Guntim), nas abas do monte $\mathrm{Meda}^{40}$. Ora bem, a villa de Montouto -ou parte dela-é um dos bens que o conde Múnio Rodrigues (1033-1074) entregou em usufruto à (segunda) mulher, Ilduara Vasques, em 1074: "Monte Auto cum adiunctionibus et criatione sicuti in suos scriptos resonat" ${ }^{\prime 4}$. Essa mesma propriedade será mencionada por Soeiro Moniz, filho desse Múnio Rodrigues, entre aquelas que deu à Sé de Lugo ${ }^{42}$. A herdade em questão voltará a ser referida, em 1166, no testamento de Bernardo Moniz, um filho de Múnio Pais de Monterroso e de Lupa Peres de Trava: "mando a Sancta Maria de Lugo meam porcionem de Montouto"43.

Trata-se de membros da estirpe que descende de Ero Fernandes, considerado fundador do mosteiro de Ferreira de Palhares na segunda metade do séc. IX. O tronco principal da linhagem é relativamente bem conhecido, até porque contamos com uma Renembrança genealógica elaborada no mosteiro ca. $1265^{44}$. A ela pertenceu Múnio Pais, conde de Monterroso (1105-1142 $)^{45}$ e esposo de Lupa Peres de Trava (1111-1167), importante cavaleiro nas cortes da rainha Urraca e de Afonso VII, cujo túmulo

36 Em sequência, corresponde a áreas dos atuais concelhos de Santisso, Palas, Lugo, Guntim, Portomarim e Taboada.

37 Sobre esta rua e o seu relacionamento com a Sé, veja-se Portela Silva e García Oro (1997: 108-111).

38 A respeito de uma das situadas nesta vila, indica que se trata de "magna domo". A vila de Portomarim constitui, como veremos, uma localização recorrente nas posses dos Monterrosos.

39 AHN, L.1040, fl. 8r; Jiménez Gómez (1987: 167).

40 A antiga Vila de Montouto também se terá estendido pelas atuais freguesias de Lamela e Gomelhe. Nesta última reaparece o topónimo Montouto, que já encontrávamos em Sirviám -a 2,5 km.

41 AHN, Most. de Ferreira de Palhares, 1082, $\mathrm{n}^{\circ}$ 6. A referência vai precedida doutras (genéricas e concretas) que não deixam margem para dúvidas sobre a localização. Na escritura também se citam propriedades em Dorra (conc. Antas de Ulha), Narla (conc. Friol), Prógalo (conc. Lugo) ou Ulhoa (conc. Palas de Rei).

42 "De Sancto Iacobo Inter Ambas Aquas XII cum suis adiunctionibus et familia de Monte Alto XII", de Servilani VI" $"$ (AHN, L.1043, fl. 61v [1094]). Soeiro Moniz foi marido de Sancha Vélaz, filha de Vela Oveques (membro destacado da linhagem dos Vélaz). A entrega faz-se de modo prospetivo, já que estava na posse de Ilduara Vasques, madrasta do doador.

43 AHN, Most. de Ferreira de Palhares, 1082, n 12.

44 Souto Cabo 2012: $\mathrm{n}^{\mathrm{o}}$ 13. Salazar Acha (1984) é autor de um estudo sobre a realidade histórica desse texto. Nesse trabalho, em geral correto, registamos algum lapso, como aquele que comete ao identificar uma Aldonça [Martins] como filha de Múnio Pais de Monterroso, contrariando, em vários modos, o que lemos no original (AHN, Cat. de Lugo, 1327A, no 26-27 [1221]) e ainda na cópia do Tombo Novo (AHN, L.267, fl. 197v). Veja-se também D’Emilio 1996: 77 e Rey Caíña 1983: 90-94.

45 A presença do topónimo no título condal não tem a ver com uma eventual existência de vínculos parentais com a linhagem a que denominamos "Monterroso". 
se conserva no claustro do mosteiro ${ }^{46}$. Noutro ramo da linhagem encontramos outra protetora do mosteiro (cf. infra): a condessa Fruilhe Fernandes (esposa de Rodrigo Peres de Trava), avó de Rui Dias dos Cameros, trovador galego-português ${ }^{47}$. A coincidência patrimonial notada pode ser indício da convergência, nalgum ponto, dos antecedentes familiares da abadessa com a estirpe citada, mas não contamos com elementos que nos permitam identificá- $\mathrm{la}^{48}$.

\section{De illis de Mirapixe}

A respeito dos sobrinhos beneficiados por Gontrode Rodrigues, não conhecemos outros rastos documentais, além dos citados, em que possamos identificar, com alguma certeza, a pessoa de Gonçalo Fernandes de Mirapeixe; pelo contrário, são relativamente frequentes os correspondentes a Rodrigo Fernandes de Mirapeixe entre 1216 e 1229 . O primeiro está representado pela concessão, em prestimónio, da vila de Erosa -hoje Orosa- (conc. Palas de Rei) que lhe faz o bispo de Lugo em fevereiro de $1216^{49}$ [D.4]. Trata-se da única escritura de que ele é titular, uma vez que nas três restantes surge apenas a testemunhar atos documentais protagonizados por Rodrigo Gonçalves de
Trava, o mais antigo (1225.02.06) [D.5], e por Rodrigo Gomes de Trava -sobrinho do anterior-nos restantes $(1229.09,1229.11 .09)$ [D.6, 7]. Estes últimos asseguram, portanto, que Rodrigo Fernandes formou parte, sucessivamente, da mesnada dos magnates citados.

O nome de Rodrigo Fernandes de Mirapeixe voltará a reaparecer na documentação, mas já na qualidade de falecido. O seu óbito produziu-se antes -talvez muito antes- de 17 de agosto de 1249 , segundo se deduz da declaração de Maria Dias quando, por ocasião da entrega de uma propriedade em Santa Eulália de Mazoi (conc. Lugo) à Sé de Lugo, nessa data, lembrava que fora mulher desse cavaleiro: "fui uxor domni Ruderici Fernandi de Mirapeixe" [D.12]. Por sua vez, Martim Rodrigues, filho dos anteriores e cónego tesoureiro da Sé de Mondonhedo, irá estabelecer, em 1257, os aniversários fúnebres dos progenitores e de uma irmã, Maior Rodrigues, segundo ficou consignado nos Calendários dessa Sé ${ }^{50}$. Três anos mais tarde, o tesoureiro ordena, no seu testamento, a entrega ao Cabido mindoniense de quantia monetária sobre umas casas da sua propriedade em Mondonhe$\mathrm{do}^{51}$, sendo provável que tenha falecido pouco

46 Múnio Pais foi filho de Paio Gomes - dos Béni Gomes de Carrión- e de Elvira Moniz, membro da linhagem dos fundadores do mosteiro. Sobre ele, veja-se também Torres-Sevilla 1999: 112-125, 351.

47 Relativamente à área geográfica em questão e aos seus possuidores, veja-se D’Emilio 1996: 50-53, 88-89. Esse estudioso sublinha a importante presença da linhagem dos fundadores de Palhares no espaço, dominado pelo monte Meda, em que confluem os atuais concelhos de Lugo (SW) e Guntim (NW). Notemos, aliás, que o casal de Montouto não é única propriedade de Gontrode Rodrigues nessa zona, já que contava com direitos de patronato sobre o mosteiro de Bacurim e a igreja de Mera, situados na vertente norte desse mesmo espaço.

48 No inquérito relativo ao contencioso que, sobre a posse do vilar de Couso, se produziu entre a Ordem do Templo e o mosteiro de Ferreira de Palhares, os Monterrosos aparecem qualificados como "herderos de Monte Roso" ou simplesmente "erderos". Valdés Blanco-Rajoy (2016: 209) supõe que, por essa denominação, os Monterrosos foram "descendientes de los condes fundadores del monasterio" de Ferreira de Palhares. No entanto, do nosso ponto de vista, parece ser o Hospital de Pena Godom a instituição a respeito da qual são assim qualificados e não o mosteiro palharense, com o qual não evidenciam vínculos especiais (cf. infra).

49 A forma Orosa é uma variante evolutiva de "Erosa" (< lat. EDEROSA). Registamos esta última na freguesia de Santa Eulália de Adá (conc. Chantada), mas a localização na área de Palas de Rei coaduna-se com o que sabemos sobre a geografia patrimonial da família.

$50 \quad$ "VI idus augusti. Eodem die obiit domnus Rodericus Fernandi miles de Mirapexe et domna Maior Roderici filia eius, pro quorum anniversario domnus Martinus Roderici, filius eiusdem Roderici, thesaurarius mindoniensis, assignavit canonicis annuatim $\mathrm{V}^{\mathrm{e}}$ solidos per domum quam comparauit in Villamaiore, a Petro Bandoia, cum domna Maria Didaci matre sua, et per exitum suum et II denarios pro oblationibus et alium pro precone et hoc capituli administrator faciat compleri per illam. Sepulta est domna Maior Roderici ad portam Sancte Trinitatis. Era. Ma CC $^{\mathrm{a}}$.LXL $\mathrm{LX}^{\mathrm{a}}$. $V^{\mathrm{a}}$ " (ACM, Calendários II, fl. 59v; Cal Pardo 2005: $n^{\circ}$ 74), "III' idus augusti. In eodem die obiit domna Maria Didaci uxor domni Roderici Fernandi de Mirapexe et domna Maior Roderici filia sua, pro quorum anniversario assignavit domnus Martinus Roderici thesaurarius mindoniensis, filius ipsius domne Marie, canonicis annuatim V solidos, per domum suam cum exitu suo quam comparavit cum eam in Villamaiore, a Petro Bandogia, et II denarios pro oblacionibus et I denario pro precone. Era $M^{\mathrm{a}} . \mathrm{CC}^{\mathrm{a}} \cdot \mathrm{LXL}^{\mathrm{a}}$. $\mathrm{V}^{\mathrm{a}}$. Sepulta est Maior Roderici ad portam Sancte Trinitatis et faciat ista ad impleri administrator capituli per illa" (ACM, Calendários II, fl. 60v; Cal Pardo 2005: $\mathrm{n}^{\circ}$ 75).

51 "Domnus Martinus Roderici, thesarurarius mindoniensis, qui reliquit canonicis eiusdem V solidos legionenses annuatim per domos suas quas fecit et emit in hereditate que fuit Veremundi Bispi et per hereditatem ipsam et per aliam domum qui ibi facienda est pro suo anniversario, que sunt prope botecam canonicorum, via publica mediante. Era M.CC.XC.VIII. Iacet ad portam capelle extra" (ACM, Calendários I, fl. 68v; Cal Pardo 2005: ${ }^{\circ}{ }^{116}$ ). 
tempo depois ${ }^{52}$. Garcia Fernandes de Mirapeixe surge, pela primeira vez, em fevereiro de 1230 , num ato documental pelo qual adquiria uma herdade em Ver (Cela, conc. Outeiro de Rei), portanto numa área muito próxima de Mirapeixe $[\mathrm{D} .8]^{53}$. De modo similar ao que foi notado em relação a Rodrigo Fernandes, nas atestações restantes, Garcia Fernandes figura entre as testemunhas de três diplomas cujo titular é Rodrigo Gomes de Trava: dois no dia 31 de dezembro de 1237 [D.9, D.10] e outro em 12 de junho de 1243 [D.11]. Como no caso anterior, cabe concluir que este irmão do poeta integrava o séquito desse último.

As duas redações do testamento de Teresa Fernandes de Mirapeixe, lavradas nos dias 29 e 30 de setembro de 1251, constituem outra importante fonte de informação sobre a família dos Mirapeixes [D.13, D.14] $]^{54}$. Junto com montantes monetários, um rocim e objetos diversos, D. ${ }^{a}$ Teresa distribui por elas: uma arca

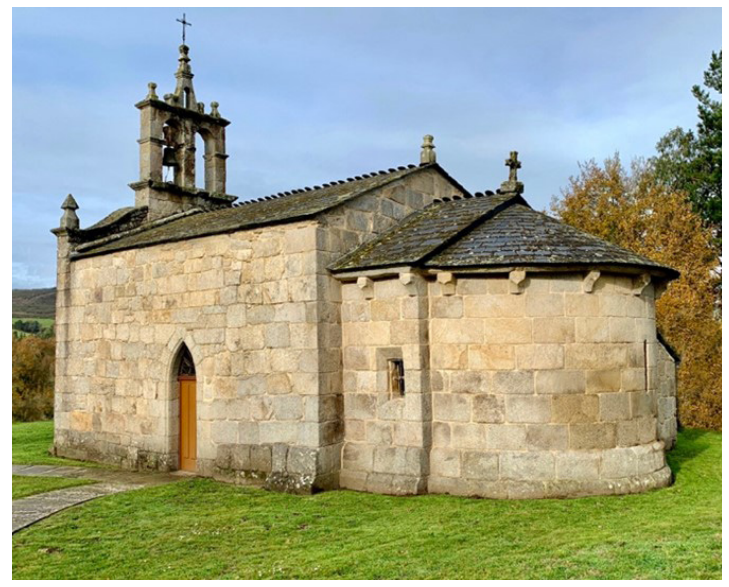

Santiago de Francos na antiga terra de Mirapeixe depositada na igreja de Tirimol (conc. Lugo), a "medam veterem" de Mirapeixe e a parte que lhe pertencia no patronato da igreja de S. Vicente de Pias (conc. Lugo). Quanto aos beneficiários, menciona-se: a Sé de Lugo, o capelão do bispo, hospitais, leprosarias, a igreja de Tirimol (conc. Lugo), a de Gaioso (conc. Outeiro de Rei) e a de Francos (conc. Outeiro de Rei) ${ }^{55}$.

Além de Domingos Eanes, capelão do bispo, o elenco de testemunhas da primeira versão inclui, Pedro (II) Fernandes de Mirapeixe, irmão da testadora, junto com a mulher Urraca Nunes ("eius uxor") e um filho deles, Pedro Cabeça ("eius filius"). Logo a seguir encontramos Domingos Peres de Mirapeixe, mas neste caso não há indicação sobre qualquer vínculo familiar com esse "Petrus Fernandi de Mirapeixe", o que nos leva a pensar que não era filho dele (cf. infra). A variante expandida da manda, lavrada no día seguinte, mostra novidades na nómina de testemunhas e no modo como elas são apresentadas. Assim, desaparece o nome de Domingos Peres, mas são incorporados os de Maria Fernandes e Gontrode. Por outro lado, também se omite o apelido linhagístico "de Mirapeixe", bem como qualquer referência ao tipo de vínculos familiares entre os indivíduos citados. Ora bem, se estabelecermos um paralelismo com o diploma mais antigo, em que todas as testemunhas (propriamente ditas) são familiares de Teresa Fernandes, será possível concluir que Maria Fernandes e Gontrode [Fernandes?] foram irmãs dela ${ }^{56}$.

Teresa Fernandes declara, logo no início do primeiro testamento, encontrar-se "infirmitate gravata", o que nos leva a suspeitar que poderá

52 É isso que deduzimos da referência, em 1278, à adega que lhe pertencera -veja-se a nota anterior-e que, na altura, era propriedade de Marina Peres de Lugo (Cal Pardo 2005: $\mathrm{n}^{\circ}$ 231). Os Calendários mindonienses conservam outras notícias sobre ele, incluindo referência a outros bens em Mondonhedo (Ibid.: nº 70, 234, 1619, 1623, 1656, 1669, 1731). Cal Pardo (2005: 747) identifica-o erradamente com um "magistrum Martinum thesaurarium" que ainda era vivo em 1288 (Ibid.: 310, 314).

53 Ele deverá ser o cavaleiro, já falecido, a que se alude numa escritura de 1268 como pai de Aldara Garcia (Souto Cabo 2008: $\mathrm{n}^{\circ}$ 243; AHN, Cat. de Lugo, 1330F, no 22). Por esse ato documental, a filha permutava com Fernando Peres de Arceo posses situadas em Cela e em Tavoi (conc. Outeiro de Rei) em troca doutras em Ferreira (de Lemos). Pelos dados desse diploma e doutros de 1266, sabemos que Garcia Fernandes casara, em segundas núpcias, com uma Sancha Fernandes e que esta também o fizera, nessa mesma condição, com esse Fernando Peres de Arceo. Aldara Garcia foi mulher de um Fernando Garcia de Ferreira e mãe de um Garcia Fernandes (Souto Cabo 2008: $\mathrm{n}^{\circ}$ 208, 210; AHN, Cat. de Lugo, 1330D, nº 26; 1330E, nº 5).

54 Note-se que a finalidade dos citados testamentos, como é frequente para os sécs. XII e XIII, não era distribuir a totalidade dos bens, mas referir apenas aqueles casos não contemplados pelas normas hereditárias habituais.

55 A entrega da "medam veterem de Mirapeixe" às igrejas de Francos e Gaioso evidencia, como dissemos, que é nessas freguesias que se situava o solar originário dos Mirapeixes.

56 Maria Fernandes poderá ser identificada com a personagem homónima que deu, em 1259, uma herdade em Mazoi e o seu direito de patronato na igreja dessa paróquia ao bispo de Lugo (AHN, Cat. de Lugo, 1329E, $\mathrm{n}^{\circ}$ 14). 
ter morrido pouco tempo depois ${ }^{57}$. No entanto, a confirmação do seu óbito só se produzirá em 31 de maio de 1260, altura em que Maior Airas, ao entregar à Sé de Lugo o direito de patronato que lhe correspondia na igreja de Santa Eulália da Pena (conc. Begonte) ${ }^{58}$, declara ter sido filha de Teresa Fernandes de Mirapeixe [D.16]: "que fui filia domne Taresie Fernandi de Mirapexe". Pelo LA sabemos que Maior Airas faleceu em 19 julho de 1271 e que deixou à Sé de Lugo tudo o que possuía em Uriz (conc. Begonte) ${ }^{59}$. Essa fonte também desvenda a existência de uma irmã da anterior, Maria Airas de Mirapeixe, com quem partilhava aquelas propriedades ${ }^{60}$. Desconhecemos quem foi o marido de Teresa Fernandes de Mirapeixe e pai de Maior e Maria Airas, no entanto, entre as diversas hipóteses possíveis, talvez seja de considerar a identificação dele com Airas Peres de Montenegro. A presença dele, em 1229, como testemunha de um documento de que é titular Rodrigo Gomes de Trava sugere que formava parte do séquito desse magnate, junto com Rodrigo Fernandes de Mirapeixe [D.7].

Nos dois exemplares do testamento acima citado surge, entre os confirmantes, o nome de Pedro Cabeça, notando-se, na primeira versão, que era filho de Pedro (II) Fernandes de Mirapeixe. Ora bem, em duas escrituras de $1257^{61}$ e $1264^{62}$ aparece mencionado um frade do mosteiro de Ferreira de Palhares, com esse nome, que poderá ser o sobrinho de Teresa Fernandes de Mirapeixe [D.15, D.17] ${ }^{63}$. Nos dois casos, trata-se de referências àquilo que pertencera ao religioso em Santa Maria de Zolhe (conc. Guntim) ${ }^{64}$.

Aquilo que expusemos nas secções prévias convida a pensar na existência de dois "Pedros" entre os irmãos do trovador, tendo sido o mais velho pai de Domingos Peres e o mais novo aquele que testemunha a manda de Teresa Fernandes e foi progenitor de Pedro Cabeça. Além da evidência que fornece o testamento dessa dama, motivos de ordem cronológica aconselham a considerar a existência de duas pessoas com percursos vitais não coincidentes. O primeiro desses dois "Pedros" terá sido citado por Pallares Gaioso (1700: 383) na referência confusa a uma escritura, hoje em paradeiro desconhecido, que se encontrava no arquivo da Catedral de Lugo:

En un legajo (36) de antiguas escripturas del Archivo he visto una de la era de 1291, que es año 1253, en que el Obispo de Lugo D. Rodrigo y Rodrigo Pelaez de Montenegro hicieron trueque de las dos tercias partes del Monasterio de S. Miguel de Bacorin, que avian donado a la iglesia de Lugo Pedro Fernandez de Mirapeixe, y sus hermanas D. Aldonza Rodriguez y D. Contralda Rodriguez, monjas naturales de

57 Contamos, ao menos, com outra (provável) referência a essa irmã do trovador em 1252.03.10 (AHN, Cat. de Lugo, $\left.1328 \mathrm{~F}, \mathrm{n}^{\circ} 13,14\right)$. Nela, alude-se a propriedades "adquiridas" -por meios que não se especificam- pelo bispo de Lugo, pouco tempo atrás, em S. João de Tirimol de uma "domna Taresia Fernandi”, que cabe identificar com a

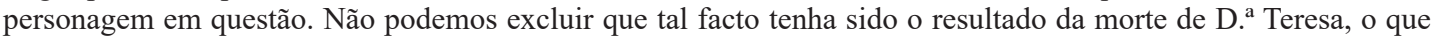
supõe a existência prévia de algum tipo de negócio económico com o bispo que se teria ativado após o passamento dela. Por este ato documental, Maior Airas, filha de Airas Peres de Parga, entregava ao bispo de Lugo propriedades em Tirimol (conc. Lugo), Sá (conc. Lugo), Carvalhido (conc. Lugo) e Pias (conc. Lugo), ficando, em compensação, com o usufruto dessas e doutras posses (cf. infra). Por um escrito de 1253, sabemos que Airas Peres de Parga foi marido de Maria Rodrigues (AHN, Cat. de Lugo, 1328G, n 11). Um "Garsias Fernandi, miles" confirma esse ato documental.

58 Entre as testemunhas desse escrito encontra-se Múnio Pais, abade do mosteiro de Ferreira de Palhares ("Munio Pelagii, abbas de Ferraria, testis"), o que sugere a existência de algum vínculo familiar com a doadora.

59 "XIIII kalendas augusti. Anniversario Maioris Arie que dat totam hereditatem suam de Ooriz. Era M. ${ }^{a}$ CCC.IX." (AHN, L.1041, fl. 18v; Jiménez Gómez 1987: 197) (cf. infra).

60 "Anniversarium Marie Arie de Mirapeixe que dedit totam hereditatem suam de Ooriz" (AHN, L.1042, fl. 12r; Jiménez Gómez 1987: 222). "Datur hereditas de Ooriz, vidilicet Marie Arie et sororis sue Maioris Arie, domno Matheo archidiacono pro XX soldos alfonsinos annuatim” (AHN, L.1042, fl. 33v; Jiménez Gómez 1989: 1482).

61 AHN, Most. de Ferreira de Palhares, 1083, n 23; Souto Cabo 2008: 90, $\mathrm{n}^{\circ} 70$.

62 AHN, Most. de Ferreira de Palhares, 1090, $\mathrm{n}^{\mathrm{0}} 6$.

63 Os Calendários da Catedral de Mondonhedo referem a existência de um Pedro Peres, chamado "Cabeça", racioneiro da Sé, documentado entre 1280 e 1298 (Cal Pardo 2005: nº 237, 400, 402). A grande distância temporal impede a identificação com o indivíduo em questão.

64 A referência ao frade, no segundo dos escritos, sugere que ele já falecera: "quanta herdade avia in a fiigregia de Sancta Maria de Zule". As senhoras com as quais o mosteiro chega a um acordo sobre as propriedades do religioso poderiam ser filhas de duas irmãs do mesmo (Marina e Azenda Peres). Pedro Cabeça voltará a ser mencionado, de modo retrospetivo, num inventário de propriedades do mosteiro lavrado em 1287: "In casal de Pay Nuguera, herdamento de Pedro Cabeza que foy nosso frade" (AHN, Most. de Ferreira de Palhares, 1096, n 12). 
Mirapeixe, dos leguas de esta ciudad, donde está la casa solariega de los Gaiosos, de que se infiere, que D. Rodrigo sucedió a D. Fr. Arias.

Além dos lapsos, como o de Contralda por "Gontrode" ou a consideração de Pedro Fernandes de Mirapeixe como irmão das religiosas $^{65}$, é óbvio que existe um importante erro na datação, visto que só existem dois bispos de Lugo com esse nome, aliás contíguos, antes do séc. XIV: Rodrigo I [Mendes] (1181-1182) e Rodrigo II [Fernandes] (1182-1218) ${ }^{66}$. Quanto a Rodrigo Pais de Montenegro, contamos com registos documentais para ele entre 1190 e 1205 , período que poderá corresponder, grosso modo, com a última fase do seu percurso vital $^{67}$. Um documento de 1203.06.26 contém, muito provavelmente, a memória do ato documental referido por Pallares Gaioso, que ficaria, assim, situado mesmo antes dessa data. Com efeito, no contexto de uma transação económica produzida nesse ano, o de Montenegro faz notar que, num tempo passado, recebera bens em Bacurim por parte da Sé de Lugo ${ }^{68}$.

Seja como for, a associação de Pedro (I) Fernandes de Mirapeixe a Aldonça e Gontrode Rodrigues oferece algumas importantes pistas sobre a cronologia dele, pois sabemos que Aldonça Rodrigues morreu em 1201. Podemos considerar, assim, que este irmão do trovador já se encontrava numa idade relativamente avançada nos inícios do séc. XIII, o que condiz com a cronologia que supomos para o ato que deu origem à doação da casa na Cruz à Sé lucense (cf. infra).

A documentação considerada oferece, portanto, informações diretas sobre, pelo menos, seis irmãos do trovador. Como foi notado, há vários elementos que nos levam a suspeitar que o Pedro Fernandes (II) registado no testamento de D. ${ }^{\text {a }}$ Teresa Fernandes terá sido o segundo desse nome. Esse facto, associado à grande distância temporal que afasta os registos históricos de alguns dos irmãos, sugere que deverão ter sido filhos de duas mães diferentes. Podemos, assim, identificar sete indivíduos "Fernandes de Mirapeixe": Gonçalo (1211), Múnio, Rodrigo (1211-1229), Pedro I, Garcia (1230-1243), Teresa (1251) e Pedro II (1251). Só os quatro primeiros terão sido irmãos completos de Múnio Fernandes.

Os escassos e fragmentários dados relativos ao património dos membros desta parentela ${ }^{69}$ colocam alguns problemas para definir as áreas geográficas de implantação. Se prescindirmos do relativo à cidade de Lugo, as posses concretas mencionadas no testamento de Gontrode Rodrigues situavam-se na área territorial que fica, grosso modo, delimitada pelas freguesias de Varaçom (conc. Santisso), Bacurim (conc. Lugo) e Giám (Taboada). No caso da família Mirapeixe, observamos associação a esse espaço em Rodrigo Fernandes (Orosa, conc. Palas de Rei), Pedro (I) Fernandes (Bacurim, conc. Lugo) e Pedro [Peres] Cabeça (Zolhe, conc. Guntim) -filho de Pedro (II) Fernandes. As informações restantes situam-nos em duas áreas extremas de um território muito menos extenso, cujo epicentro seria o atual concelho de Outeiro de Rei; nele ou nas suas redondezas localizamos posses de Maria Dias ${ }^{70}$ (Gamoedo, Mazoi, conc. Lugo), Garcia Fernandes (Ver, Cela, conc. Outeiro de Rei), Teresa Fernandes (Tirimol, conc. Lugo; Pias, conc. Lugo; Mirapeixe, Francos, conc. Outeiro de Rei), Maior Airas (Pena, conc. Begonte; Uriz, conc. Begonte) -filha de Teresa Fernandes-, e Maria Airas (Uriz, conc. Begonte) -filha de Teresa Fernandes. Quanto aos vínculos de Martim Rodrigues com Mondonhedo, foram certamente resultado da integração dele no cabido mindoniense.

65 O que terá derivado na atribuição da mesma naturalidade às cenobitas.

66 García Conde (1991: 202-222). É difícil destrinçar o nó do ("aparente") engano em que incorre o cónego lucense.

67 Lamigueiro (2016: 113-115). Notemos que João Rodrigues de Montenegro, filho do anterior, faleceu em 1230 de acordo com o LA (AHN, L.1040, fl. 7r; Jiménez Gómez 1987: 167).

68 AHN, Cat. de Lugo, 1326D, no 13 . O ato documental, em presente, regista uma permuta entre o bispo de Lugo e Rodrigo Pais de Montenegro pela qual este último recebeu uma serviciália em Sante (Bulso/Brosmos, conc. Sober) em troca do usufruto de uma herdade em Vilachá [de Mera] (conc. Lugo). Esta última propriedade fora, previamente, doada à Sé lucense por esse mesmo cavaleiro, mas conservando o aproveitamento dela, agora também cedido. Foi em compensação por esta doação anterior que ele ganhara posses em Bacurim, às quais se refere retrospetivamente com várias lacunas expressivas nos seguintes termos: "ego Rudericus Pelagii delibero lucensi ecclesie hereditatem de Villa Plana, tam ecclesiasticam quam laicalem, sicut eam dederam eiusdem ecclesie pro concambium trium porcionum et unius casalis Sancti Michaelis de Bacurin".

69 O que pode ser interpretado como um indício da languidez económica que poderia estar a afetar este grupo familiar, acaso em paralelo com aquela que padece o mosteiro de Giám e resultou na extinção do mesmo.

70 Esposa de Rodrigo Fernandes de Mirapeixe (cf. supra). 
Além do nexo familiar com os Monterrosos -linhagem analisada nas alíneas que se seguem-, a documentação também nos oferece algumas pistas sobre a integração dos Mirapeixes na rede aristocrática que domina a área desde finais do séc. XII e durante a primeira metade do séc. XIII. Como vimos, é patente a relação de vassalagem a respeito do círculo de Rodrigo Gomes de Trava, grupo familiar concreto que (quase) patrimonializou as tenências de Montenegro, Monterroso, Sárria e Trastâmara desde a última década do séc. XII até meados do séc. XIII (Bermúdez Beloso 2017: 477-488) ${ }^{71}$. Aliás, é interessante notar que uma parte do interesse fundiário deste ramo dos Trava se concentrava na terra de Parga, portanto, numa área relativamente próxima de Mirapeixe, a meio caminho entre Monterroso e Montenegro ${ }^{72}$. Na condição de subordinados a este ramo dos Trava, os Mirapeixes aparecem associados a outras parentelas da região cujos membros também estão presentes em diplomas de que foi titular Rodrigo Gomes, no quais também registamos Rodrigo e Garcia Fernandes de Mirapeixe. De acordo com a presença explícita do apelido linhagístico, podemos identificar, entre outras, as seguintes: Aguiar (Rodrigo Fernandes) ${ }^{73}$, Andrade (Fernando Peres), Asma (Gil de Asma), Bamonde
(João Rodrigues), Bolanho (Pedro Rodrigues), Duancos (Fernando Afonso), Goiôs (Rodrigo Sebastiães), Lemos (Afonso Lopes), Montenegro (Airas Peres, João Rodrigues), Parga (Airas Peres, Pedro Rodrigues), Robra (Afonso Pais), Rodeiro (Múnio Fernandes) ou Savedra (Lopo Rodrigues).

Entre as citadas, talvez seja a de Montenegro aquela que mais se aproxima, mesmo espacialmente, dos Mirapeixes. Estas duas parentelas parecem ter ocupado setores coincidentes ou complementares da terra ou vale de Goiôs -na atualidade Gaioso $^{74}$-, correspondendo aos primeiros a área oriental ${ }^{75}$. Por outro lado, a relação vassalática notada a respeito dos Trava é especialmente clara por parte dos Montenegro $^{76}$. Com efeito, já o primeiro membro conhecido da linhagem, Paio Rodrigues ${ }^{77}$, surge como mordomo do conde Gomes Gonçalves, o pai de Rodrigo Gomes, em 1171: "Pelagius Roderici, maiordomus comitis" (Loscertales 1976: I, no 543). Ao abrigo dessa conexão, João Rodrigues de Montenegro (1199-1230), filho de Rodrigo Pais e neto do anterior, conseguiu aceder ao poder político em Gaioso e no conjunto de Montenegro, como prestameiro (1217) e como tenente (1217-1222), certamente promovido por Rodrigo Gomes ${ }^{78}$. Além dos

71 Esse vínculo está na base da, já tradicional, associação de Múnio Fernandes de Mirapeixe a Rodrigo Gomes, já proposta por López Ferreiro (1902: 371-372). Veja-se também Oliveira 1994: 394-395, Vieira 1999: 116-120, Monteagudo 2008: 332-333 ou Souto Cabo 2012: 206.

72 O conde Gomes Gonçalves entregava, em 1184, à Ordem do Hospital herdades na terra de Parga (García Tato 2004: $\mathrm{n}^{\circ} 42$ ). Por seu turno, Rodrigo Gomes recompensou o bispo de Lugo com tudo aquilo que possuía em Lea (Guitiriz), nessa mesma área, por violências cometidas contra a Igreja lucense [D.7].

73 O atual arciprestado de Aguiar está formado pela metade oriental do concelho de Outeiro de Rei, salvo três freguesias que pertencem ao mindoniense da Terra Chá. O sector mais ocidental fica integrado no arciprestado lucense de Friol.

74 De acordo com as fontes documentais, o território de Gaioso ocupava, grosso modo, a margem sul do espaço situado entre a confluência do rio Parga com o Ladra e a deste último com o Minho. A forma medieval romance é "Goiôs", derivada provavelmente de uma (VILLA) GAUDIOSI, reinterpretada posteriormente como "Goioso" ou "Gaioso", a partir de "Gaiosos".

75 Em relação a esse território, Lamigueiro (2016) registou posses dessa estirpe nas freguesias de Castro, Pena, Trobo e Viris (conc. Begonte). Este investigador oferece informação sobre a linhagem em questão.

76 Ron Fernández (2015: 644), tomando como base a alusão contida no testamento de Gontrode Rodrigues à terra de Montenegro, ponderou a possibilidade de que "o feito de que as tías do trobador se apeliden Roderici, e que teñan a voz de Montenegro, permítenos formular a hipótese de que a parentela orixinaria dos Mirapeixe sexa a de Montenegro", do qual se pode deduzir que o pai dos Fernandes de Mirapeixe teria sido, segundo o nosso colega, irmão de Gontrode. Porém, o lacónico dessa referência não deixa transparecer, em princípio, um nexo patrimonial vigoroso com aquele antigo condado, de facto as propriedades da abadessa concentravam-se, como vimos, nas terras de Aveancos, Monterroso e Portomarim.

77 Uma escritura de 1194, em que se alude de modo retrospetivo a ele, talvez nos permita situar as origens familiares em terras do concelho de Vilalva, no coração de Montenegro (AHN, Cat. de Lugo, 1326A, nº 9). Por ela sabemos que Paio Rodrigues e a mulher, Elvira Nunes, contaram com posses na villa de Cendoi (Santavalha, conc. Vilalva).

78 O exercício desse cargo aparece associado - e sujeito- ao domínio exercido pelos dois filhos do conde: Rodrigo Gomes e Vasco Gomes: "Domno R[oderico] Gomiz tenente Trastamar et Monterroso et Sarr[i]a et Monte Nigro. Johannes Roderici prestameyro da terra" [1217], "Rodericus Gomet ricome. Domnus Johannes Roderici tenens terra" [1218], "Roderico Gomecii tenente Galletiam [...]. Johanne Roderici tenente Montem Nigrum" [1218], "Don Vaasco [Gomez] ricome. Don Johannes Roderici tenens ibi a terra" [1220], "Domno Roderico Gomet ricome. 
Montenegro, os Goiôs ${ }^{79}$ e os Parga mantiveram vínculos sociofamiliares com a linhagem do trovador $^{80}$.

\section{Arie Petri de Monterroso}

Airas Peres e os filhos integravam, como vimos, o primeiro grupo de indivíduos citados na Notícia da casa da Cruz ${ }^{81}$. De acordo com a nossa proposta, ele deverá ter sido tio-avô do poeta, enquanto irmão da miona Urraca de Giám (avó dos Fernandes de Mirapeixe). Contamos com vários registos documentais, entre 1153 e 1167, para quem foi o principal representante da linhagem dos Monterrosos -acaso como único filho varão de Pedro Eanes ${ }^{82}$. No mais antigo, este cavaleiro forma parte dos nobres que confirmavam uma doação ao mosteiro de Sobrado por parte dos irmãos Fernando e Bermudo Peres de Trava, o que logo sugere um vínculo de dependência a respeito dos Travas ${ }^{83}$. Ele poderá ser o personagem homónimo que, em 1158, subscreve um privilégio pelo qual Fernando II entregava à Ordem de S. João de Jerusalém o mosteiro de Santa Marinha (conc. Portomarim) e o realengo de
Portomarim (García Tato 2004: $\mathrm{n}^{\mathrm{o}}$ 13) ${ }^{84}$. Em 1160, aparece como um dos três nobres que julgaram o contencioso que existia entre Fernando Oares e Gontrode Soares, abadessa de Doçom $^{85}$. Muito provavelmente, ele deverá ser ainda identificado com o "Arias Petri tenens Castellum de Monte Roso" 86 que confirma, em 1167, uma doação de terras em Palhares à Sé de Lugo por parte do monarca citado (Cañizares 2015: $\left.\mathrm{n}^{\mathrm{o}} 272\right)^{87}$.

O quinhão que coubera a Airas Peres de Monterroso no prédio da Cruz tinha sido, por sua vez, distribuído entre sete filhos: João Airas (deão), Pedro Airas, Diogo Airas, João Airas de Arcos, Fernando Airas de Vila Nova, João Airas de Monterroso e Rodrigo Airas ${ }^{88}$. Expomos a seguir alguns dos dados históricos que conseguimos coletar sobre estes cavaleiros. Reconhecemos que esta secção, até pelo seu desenvolvimento, pode parecer um tanto ou quanto distante do objetivo central deste trabalho, mas o interesse histórico e ainda cultural leva-nos a mantê-la por não existir um trabalho monográfico sobre os descendentes de Airas Peres de Monterroso.

Domno Johannes Roderici tenens ibi a terra" [1222] (Loscertales 1976: II, $\mathrm{n}^{\circ}$ 522, 525, 526, 530, 531). Salvo no caso da alusão explícita à tenência de Montenegro, devemos supor que o cargo de prestameiro ou de tenente é referido apenas ao território de Gaioso, espaço em que se situam os bens objeto de negócio económico.

79 Esta estirpe, que utilizou "Goiôs" como apelido linhagístico, parece ter suposto a continuidade, pelo menos em parte, dos Mirapeixes (Pardo de Guevara y Valdés 1996: 89-97). O vínculo com a terra de Gaioso também se evidencia por dados patrimoniais, como os relativos a Adosinda Soares de Goiôs, Lopo Eanes de Goiôs e Pedro Eanes de Goiôs (Jiménez Gómez 1987: 180, 220-221). Eles contaram com propriedades em Caboi (conc. Outeiro de Rei) e Uriz (conc. Begonte), freguesias contíguas na área de Mirapeixe. Numa escritura pela qual entrega à Sé de Lugo uma herdade em "Palagios de Veiga", Pedro Eanes de Goiôs declara-se subdito de Rodrigo Gomes de Trava (AHN, Cat. de Lugo, $1326 \mathrm{H}, \mathrm{n}^{\circ} 9$ [1217]).

80 Os Pargas são o resultado do casamento de Pedro Eanes de Goiôs com Ermesenda Oveques. O topónimo remonta à antiga terra de Párrega, situada na área mais oriental do atual concelho de Guitiriz, limítrofe com o de Begonte. A ascensão social desta família, desde as primeiras décadas do séc. XIII, reflete-se no facto de dois bispos da mesma terem presidido a Sé de Lugo: Miguel Peres (1226-1270), filho de Pedro Eanes e de Ermesenda, e Fernando Airas (1270-1276), sobrinho do anterior. Sobre esta parentela, veja-se García Conde 1993: 227-235, 237-240 e D’Emilio 2008: 213.

81 Este cavaleiro aparece, não raro, confundido com o Airas Peres (de Deça) -irmão de Luzo Airas- que foi marido de Aldara Peres, filha de Pedro Froiaz de Trava.

82 O $L A$ regista, em março de 1183, a morte de uma Maior Peres que deixou à Sé de Lugo, para o seu aniversário e o do marido, Airas Peres, um casal que compraram em Melide (AHN, L.1040, fl. 23v; Jiménez Gómez 1987: 177). Poderia tratar-se de Airas Peres de Monterroso e da mulher, mas a ausência de apelido linhagístico coloca algumas dúvidas.

83 "Arias Petri Montis Rosi veram istam cartam esse non cesso" (AHN, L.976, fl. 10v; Loscertales 1976: II, n 14).

84 Notemos, contudo, que neste caso o seu nome não é acompanhado do topónimo.

85 "[...] ad iudicium ante comitem Gunzalvum et ante Arias Petri de Monte Roso et Fernando Fernandiz de Salnes" (Viana y Vieites 2009: $n^{\circ} 23$ ).

86 Esse castelo estaria situado entre Sirgal (conc. Monterroso) e Argiz (conc. Taboada).

87 Bernardo Moniz, um filho de Múnio Pais de Monterroso e Lupa Peres de Trava, cita no seu testamento os filhos de um Airas Peres aos quais manda entregar, de modo prospetivo, uma herdade em Pradeda (conc. Guntim) (AHN, Most. de Ferreira de Palhares, 1082, no 12 [1166]); mas não temos dados que nos permitam a identificação dele com o cavaleiro em questão.

88 Os topónimos "Arcos" e "Vila Nova", apensos aos nomes de João Airas (II) e Fernando Airas, remetem para as freguesias homónimas dos atuais concelhos de Antas de Ulha e Monterroso. 


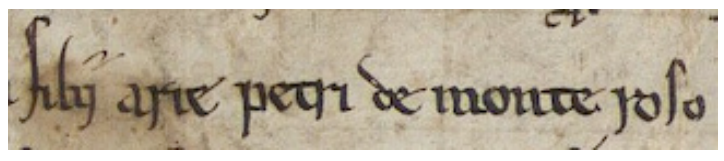

O sucessor de Airas Peres nomeado em primeiro lugar -aliás, quem atingiu maior notoriedade pública- é João Airas, deão da Sé lucense ${ }^{89}$ desde 1182 até $1214^{90}$. Entre as empresas em que ele participou, o destaque vai para a introdução, em 1194, da Ordem de Santiago no mosteiro de Vilar de Donas. Nesse ano, o deão, pelo conjunto dos filhos de Airas Peres de Monterroso ("filii Arie Petri de Monte Roso"), e outros "herdeiros" -isto é, descendentes dos fundadores- entregaram o cenóbio a essa Milícia, lembrando que se tratava de um mosteiro familiar, pelo qual mantiveram algumas prerrogativas sobre ele ${ }^{91}$. De facto, até ao momento da sua morte, o deão terá participado na administração do mosteiro, como se deduz da sua presença entre os confirmantes dos primeiros atos documentais relativos a essa instituição. Como dissemos, ele também testemunha o testamento de Gontrode Rodrigues, abadessa de Giám, já que se trata doutro estabelecimento monástico sujeito à tutela dos Monterrosos.
Do mesmo modo que João Airas, Pedro Airas foi destinado à carreira eclesiástica ${ }^{92}$. De acordo com o $L A$, ele morreu em 9 de novembro de 1230 e deixou à Sé de Lugo, para o aniversário, uma quantidade económica sobre dois casais: um em Remesar (conc. Bóveda) e outro em Lagares ${ }^{93}$. Como cumpridores da manda são indigitados o irmão Fernando Airas e o sobrinho, filho deste último, Rodrigo Fernandes, que também foi cónego-arcediago dessa mesma instituição (cf. infra) ${ }^{94}$. Uma escritura de 1263 em que se alude de modo retrospetivo ao cónego revela que uma parte do património de Pedro Airas se situava no antigo distrito de Toronho e em Portugal: "hereditatem ecclesiasticam et laicalem quam domnus Petrus Arie, quondam lucensis canonicus, habebat et habere debebat in toto Toronio et in Portugallia et in Amarante et in Sancto Jacobo de Dorra"95. Essa localização, que não se repete para outros membros da família, pode ser um indício sobre a linhagem da mãe ou da avó paterna, o que nos situaria no círculo dos Toronhos ou Celanovas ${ }^{96}$.

Diogo Airas e a mulher, Urraca Fernandes, tiveram uma casa em Portomarim, citada no $L A$ a propósito do falecimento dela, produzido em $1227^{97}$. No entanto, é especialmente

89 A deania tinha atribuído o território de Monterroso, com os arciprestados de Lamela, Ulhoa, Repostaria e Novelua (D'Emilio 2008: 207, n. 76).

90 De acordo com o LA (AHN L.1041, fl. 17r; Jiménez Gómez 1987: 196), ele faleceu em 13 de julho desse último ano. D’Emilio (2008: 207, 216-217) trata deste personagem, mas confunde-o com João Airas de Nóvoa, marido de Urraca Fernandes de Trava. O engano prende-se ao facto de o deão e uma Urraca Fernandes, de identidade familiar desconhecida (falecida em 1195), terem adquirido um imóvel na cidade de Lugo (AHN, L.1041, fl. 6v; Jiménez Gómez 1987: 189). Sobre João Airas de Nóvoa, veja-se Souto Cabo 2012: 103-121.

91 A data que lemos no exemplar mais antigo é 1184 (AHN, Ordens Militares, Uclés, $\mathrm{n}^{\circ}$ 366), mas parece ter sido objeto de intervenção corretiva. Veja-se Novo Cazón 1986: 40-41.

92 Rades y Andrada (1572/Alcántara: 8v) considera que Airas Peres, mestre da Ordem de Alcântara entre 1227 e 1234 , "fue hijo de Pedro Arias y nieto de Arias Perez de Monterroso, que fue cavallero poderoso en tiempo del emperador don Alonso". A partir dessa fonte, outros historiadores da Ordem repetem a mesma informação, mas pensamos que se trata da confusão nominal com os descendentes de Airas Peres de Deça (cf. supra).

93 Ele aparece entre os beneficiários do testamento do deão Soeiro (Cañizares 2015: $\mathrm{n}^{\text {o }} 349$ [1219]).

94 "V idus novembris, era $\mathrm{M}^{\mathrm{a}}$.CC ${ }^{\mathrm{a}}$.LXVIII'. Ego Petrus Arie, lucensis canonicus, assigno lucensis canonicis pro anniversario meo XL soldos per II casalia mea: unum in Remesar et alterum in Lagares. Taliter quod nepos meus Rudericus Fernandi teneat ea in vita sua et pater eius, Fernandus Arie, posteum, si superstes fuerit, post mortem vero eorum, vel si non solverint predictos XL solidos, canonici recipiant predicta casalia et habeant inde quicquid habere poterint pro meo anniversario" (AHN, L.1042, fl. 7r; Jiménez Gómez 1987: 219).

95 Trata-se de uma permuta de bens pela qual a Sé de Lugo entrega a Fernando Eanes de Abrances essas posses recebendo, em troca, outras em Remesar e em S. Pedro de Mera (AHN, Cat. de Lugo, 1330B, n 24). Dorra, que também inclui Amarante (conc. Antas de Ulha), pode ser considerada uma terra menor de Monterroso. A informação do $L A$ e desta última escritura é confirmada pelo conteúdo do seu testamento (AHN, Cat. de Lugo, 1326C, $n^{\circ} 5$ [sem data]). Nele também se estabelece a celebração do seu aniversário na Sé de Tui, com o pagamento de 21 soldos para os cónegos tudenses e a entrega de um casal depois da sua morte.

96 A documentação da Sé lucense oferece informações sobre um Pedro Airas cónego e magister que não será identificável com a personagem em questão, visto que não há coincidência na data dos respetivos aniversários (AHN, L.1042, fl. 15v, 33r, 34r, 38v; Jiménez Gómez 1987: 224; Jiménez Gómez 1989: 1293, 1399, 1487, 1506, 1702).

97 "VIII idus marcii, era $\mathrm{M}^{\mathrm{a}}$.CC $\mathrm{C}^{\mathrm{a}}$.LX'.V. Anniversarium domne Urrace Fernandi, uxoris Didaci Arie de Monterroso, que assignavit lucensis canonicis pro anniversario suo $\mathrm{X}$ solidos per domum suam de Portumarino que stat iuxta pontem, versus hospitale" (AHN, L.1040, fl. 19v; Jiménez Gómez 1987: 174). 
significativa a permuta pela qual, uma década antes, o bispo de Lugo lhes entregava um casal em Giám (conc. Taboada) e outro em Vilarvassim (conc. Portomarim) em troca doutro em Francos (conc. Guntim) ${ }^{98}$. Os casais que lhes transferia o prelado são, decerto, os mesmos que Gontrode Rodrigues dera no seu testamento à Sé de Lugo ("casale de quintáá quod est in Gean, et aliud casale in Villarvassino" [D.3]). Cabendo supor que na troca subjaz o desejo de concentração patrimonial, deduzimos que Diogo Airas e a mulher contavam com propriedades nesses mesmos locais com origem na linha de sucessão hereditária familiar.

Não conhecemos registos em que se refira de modo explícito a existência de filhos de Diogo Airas. No entanto, "domne Maiori Petri" declara-se, em 1246, "netta de domnus Didacus Arie", que supomos tratar-se do cavaleiro em questão ${ }^{99}$. Por um escrito dessa data, ela vendia a Teresa Moniz de Rodeiro (filha do mordomo régio Múnio Fernandes de Rodeiro) diversas propriedades na terra de Ínsua, no distrito de Monterroso, em concreto em (S. Facundo de) Ribas de Minho (conc. Paradela), em Frameám (conc. Monterroso) e em Soengas (conc. Portomarim $)^{100}$.

Por outro lado, a denominação de quem era abadessa do mosteiro de Giám em 1245, Urraca Dias, leva-nos a pensar que deverá ter sido filha de Diogo Airas de Monterroso ${ }^{101}$. Nesse ano, ela vendia à Sé de Lugo uma herdade na vila de Martim em S. Salvador (Francos, conc. Guntim), portanto na freguesia em que se encontrava o casal cedido pelos pais a essa instituição. A venda é justificada pelas grandes necessidades do convento: "intelligentes multas et magnas necessitates monasterii nostri" ${ }^{102}$. Noutro ato documental protagonizado pela abadessa citada (Novo Cazón 1986: $n^{\circ}$ 31 [sem data]), essa senhora chegava a um acordo com o mosteiro de Vilar de Donas pelo qual esta última instituição se obrigava a dar "reverência" (económica) anual às freiras de Giám em compensação pelos bens em Aveancos e Monterroso que lhes entregara a abadessa anterior, Urraca Airas de Monterroso - a quem nos referiremos mais à frente ${ }^{103}$.

Como vimos, três filhos de Airas Peres receberam o nome de "João". No escrito relativo à casa na Cruz, o segundo e o terceiro levam, respetivamente, apenso os topónimos de "Arcos" e "Monterroso", com certeza (também) com uma finalidade diacrítica. Não temos dados sobre João Airas de Arcos, mas um filho dele, "Petro Eanes de Arcos, milite", testemunhava uma compra de propriedades, em 1243, por parte de Múnio Fernandes de Rodeiro e da primeira mulher, Constança Martins de Orzelhom (cf. infra) ${ }^{104}$. Além de Pedro Eanes, o

98 "Nos enim episcopus supradictus cum nostris canonicis damus domno Didaco et uxori eius domne Orrace unum casale in Villarvassin cum terris cultis et incultis, montibus et suis omnibus directuris, et aliud casale in Gean; recipientes ab eis unum casale in Francos cum terris cultis et incultis, montibus, et fluminibus, canalibus, et piscariis et cum omnibus suis directuris. Et ego Didacus Arie et uxor mea domna Orraca hoc concambium cum supradicto episcopo lucense et eius ecclesia facimus" (AHN, Cat. de Lugo, 1326H, nº 15-16 [1217]).

99 Ela poderia ter sido filha de uma Marina Dias - mulher de Pedro Carvalho- que, junto com o irmão Airas Dias e o filho Martim Peres, registamos em duas escrituras de 1240 (AHN, Cat. de Lugo, 1328A, no 4 e 5). Por esses escritos sabemos que contavam com propriedades na cidade de Lugo e em Santiago de Sá (conc. Lugo). A ausência de tratamento por "don(a)" projeta alguma incerteza.

100 "de quanta hereditate ego habeo vel habere debeo [...] in territorio Monte Roso, terra nominata Insua" (AHN, Most. de Ferreira de Palhares, 1085, $\left.n^{\circ} 20\right)$.

101 Lembremos, mais uma vez, que nos encontramos perante um mosteiro familiar em que, provavelmente, muitos dos membros da pequena comunidade pertenciam à linhagem fundadora. Ela poderá ser identificada com a titular de um ato documental, representado por dois diplomas de 1260 (Cañizares 2015: $n^{\circ} 370$-erradamente situada em 1230-e AHN, Cat. de Lugo, 1329G, n 22), pelo qual entregava à Sé os seus direitos de patronato sobre a igreja de S. Salvador de Martim. Não podemos descartar que estes dois últimos escritos digam respeito de Urraca Dias de S. Mamede, mulher de Oeiro Fernandes (cf. infra).

102 AHN, Cat. de Lugo, 1328C, $\mathrm{n}^{\circ}$ 6. Tal como se indica na nota dorsal, o imóvel estava situado no couto de Francos.

103 Em dois momentos, nota-se que o compromisso económico por parte de Vilar de Donas só ia vigorar enquanto houvesse freiras no mosteiro: “dum ibidem sancte moniales conservarentur" (Novo Cazón 1986: n 31). A sobrevivência da vida monacal encontrava-se, por motivos económicos, seriamente comprometida, sendo possível que a comunidade tenha sido dissolvida pouco tempo depois; de facto, não voltamos a ter informação sobre o mosteiro.

104 AHN, Most. Ferreira de Palhares, 1085, n 13. Por esse ato documental, lavrado em Sárria, Garcia Peres de Bragança vendia a Múnio Fernandes o que possuía em Castela, Galiza e Leão. Segundo se declara na própria escritura, os seus pais foram Pedro Garcia de Bragança (parente de João Soares de Paiva) e Constança Osores (muito provavelmente filha do trovador Osório Eanes): "Garsia Petri, filio Petro Garsia de Breganza et de domna Costanza Osorii". O documento desvenda o nome real dessa dama, transformado nos Livros de Linhagens em "Sancha": "E dom Pero Garcia casou com dona Sancha Ozores, filha de dom Ozorio Eanes" (Livro Velho de Linhagens, 1F10). 
conjunto de atestadores inclui três membros das ordens militares assentadas na terra de Portomarim $^{105}$ : o comendador do Hospital em Portomarim, um freire dessa Ordem e o comendador santiaguista de Loio ${ }^{106}$.

Fernando Airas será, porventura, o freire (e comendador) santiaguista que, em 1226, transferia ao bispo de Lugo uma casa em Portomarim (cf. infra): "Ego domnus Fernandus Arie, frater milicie Sancti Jacobi, [...] facio cartam venditionis de quanto ad me spectare dinoscitur de quadam domo de Portumarino quam vocitant domum de $<$ Cruce $>$ de Fonte de Lagina que stat inter ruam Sancti Nicolai et ruam de Rio Torto" 107 . Com anterioridade, encontramo-lo numa escritura de 1209 pela qual ele e a mulher, Sancha Moniz, vendiam uma herdade em Alvarim, "sub montis Meta", na freguesia de S. Salvador do Castelo (conc. Guntim) ${ }^{108}$. Fernando Airas faleceu antes de 1240.04.20, data em que a mulher vendia à Sé de Lugo diversas herdades -algumas das quais formaram parte das suas arras- em "Villa Plana de super Ponte Minei", numa área situada entre as freguesias de $\mathrm{S}$. Pedro de Portomarim e $\mathrm{S}$. Salvador de Cortes (Paradela) ${ }^{109}$. No diploma correspondente, esta dama alude a cinco filhos, a começar pelo, já referido, Rodrigo Fernandes, arcediago da Sé de Lugo"110: "Isde[m] est quod ego domna Sancia Muniz, presentibus et concedentibus archidiacono Ruderico Fernandi, domno Petro Fernandi, Martino Fernandi et Velasco Fernandi, filiis meis, et Odoario Fernandi, filio meo concedente" 111 .

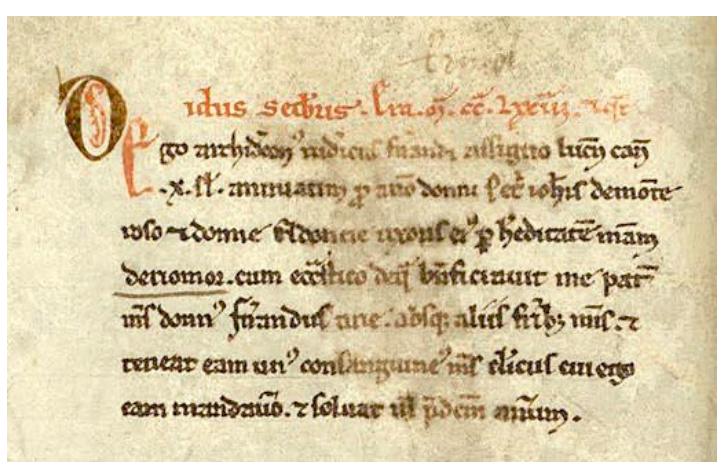

AHN, L.1041, fl. 31v

Graças às numerosas transações patrimoniais protagonizadas pelos descendentes, sabemos que Fernando Airas também teve propriedades em Ligonde (conc. Monterroso), Navalhos (conc. Guntim), Francos (conc. Guntim) e em Recelhe (conc. Portomarim), freguesia a que aparecia associada Gontrode Rodrigues. Assim, o seu filho Vasco Fernandes, cavaleiro de Santa Ougea ${ }^{112}$, estabeleceu, em 1265, uma permuta com o mosteiro de Ferreira de Palhares pela qual ele e a mulher, Urraca Martins,

105 Também registamos a presença de Fernando Pais de Rodeiro, considerado por alguns investigadores filho do comprador (Ron Fernández 2015: 268-269).

106 Este último é apresentado como "Fernando Querido, comendatore de Loyo, ts". Embora não conste a integração dele nessa Milícia, Loio foi centro da encomenda santiaguista correspondente até 1245 (Novo Cazón 1993: 53).

107 AHN, Cat. de Lugo, 1327C, ${ }^{\circ}$ 5. Nessa escritura, faz-se constar que o cónego Rodrigo Fernandes, filho desse Fernando Arias, exercia as funções do deão em Portomarim: "decano in Lugo domnus Egidio Sancii. Arrendatore suo et gerenti vicis suas in Portumarino Ruderico Fernandi, lucensis canonico" (cf. supra).

108 AHN, Most. de Ferreira de Palhares, 1082, n $^{\circ} 22$.

109 AHN, Cat. de Lugo, 1328A, nº 2. Atualmente, o topónimo Vilachá designa um local em Cortes.

110 Rodrigo Fernandes estabeleceu, em 1235, o aniversário dos bisavós sobre uma herdade em Riomol (conc. Castroverde): "Idus setembris, era $\mathrm{M}^{\mathrm{a}}$.CC $\mathrm{CC}^{\mathrm{a}}$.LXXIII et quotum. Ego archidiaconus Rudericus Fernandi assigno lucensis canonicis X soldos annuatim pro anniversario donni Petri Johannis de Monteroso et donne Eldoncie uxoris eius per hereditatem meam de Riomor cum ecclesiastico de qua beneficiavit me pater meus donnus Fernandus Arie absque aliis fratribus meus et teneat eam unus consanguineus meus clericus cui ego eam mandavero et solvat mihi predictum anniversarium" (AHN, L.1041, fl. 31v; Jiménez Gómez 1987: 209). Embora não se indique de modo explícito -dado o carácter sumário dessa fonte-, o clérigo foi, certamente, bisneto dos anteriores. O LA situa a morte do arcediago em 6 de maio de 1260: "II nonas maii, era Ma CC $^{\mathrm{a}}$.LXLa Anniversarium archidiaconi Ruderici Fernandi: XX solidos annuatim per hereditatem eius ecclesiasticam et laicalem” (AHN, L.1049, fl. 34r). Jiménez Gómez (1987: 184) reproduz a data como "Ma CC ${ }^{\mathrm{a}}$ LXVIII" (= 1230) por não ter identificado a existência do xis como aspado (=XL). De facto, os registos deste religioso vão de 1235 até 1258 (D’Emilio 2008: 208, n. 81; 253, n. 58).

111 Entre as testemunhas deste ato documental, surgem dois indivíduos a que se apõe o topónimo de Pena Godom: "Martinus Calvus de Pena Godon e Petrus Petri de Pena Godon". Como veremos, trata-se do local em que se localizava um hospital para peregrinos erguido por Pedro Eanes de Monterroso.

112 O apelido linhagístico remete para a freguesia de Santa Ougea ou Eugea (conc. Guntim), limítrofe com a de Recelhe (conc. Portomarim). Rui Vasques de Santa Ougea e Pedro Rodrigues foram, respetivamente, filho e neto deste cavaleiro (AHN, Cat. de Lugo, 1331F, no 11 [1289]). 
receberam um casal em Novelua (conc. Monterroso) em troca do quinhão que lhes correspondia no Hospital de Pena Godom (Ligonde) ("o seu quinum do Espital de Pena Godom"), um casal no lugar de Mariz, em Recelhe, e outras propriedades menores nesta última fregue$\operatorname{sia}^{113}$. Segundo declara, tratava-se de bens que foram "de seu padre, don Fernando Arias, et de seu avoo, don Arias Perez"114. Maior Fernandes de Santa Ougea -mulher de Pedro Fernandes-, outra filha de Fernando Airas, também contava com posses no lugar de Sarça em Recelhe (conc. Portomarim) ${ }^{115}$. Dispomos de numerosa informação documental sobre os seis filhos de Oeiro Fernandes -também conhecido como Oeiro Fernandes de Santa Ougea (conc. Guntim)-, marido de Urraca Dias de S. Mamede (Ribeira, conc. Páramo), parentela vincula$\mathrm{da}$ às freguesias de Navalhos (conc. Guntim) e Francos (conc. Guntim) ${ }^{116}$.

Num documento de Vilar de Donas refere-se o nome de "Johanne Arie de Monte Roso" como antigo proprietário de um casal em Linhares (conc. Santisso) ${ }^{117}$, na terra de Aveancos, o que nos leva a identificá-lo com o terceiro "João".

Reconhecemos como filho de Airas Peres de Monterroso o cavaleiro Rodrigo Airas que, junto com a mulher, Urraca Afonso ${ }^{118}$, recebia de um Fernando Pais, em $1219^{119}$, uma herdade no vilar de "Saa de Inturnados" em Bisantonha (conc. Santisso) ${ }^{120}$, também na terra de
Aveancos, a escassa distância das freguesias de Linhares e Varaçom, citadas no testamento de D. ${ }^{\mathrm{a}}$ Gontrode ${ }^{121}$.

Não conservamos o original da doação a Vilar de Donas efetuada por Urraca Airas, abadessa de Giám, mas o conteúdo desse ato documental, acima citado, foi compilado num inventário do séc. XVI (Novo Cazón 1986: n. 203). Nele, a doadora é identificada como "Urraca Ares de Monterroso", notando-se que entregara a Vilar de Donas as igrejas de S. Martim de Soengas (conc. Portomarim), Santiago de Soengas (conc. Portomarim), St. ${ }^{\text {a }}$ Maria de Narom (conc. Portomarim) e St. ${ }^{a}$ Maria de Salgueiros (conc. Monterroso). Trata-se, portanto, de uma filha de Airas Peres de Monterroso não citada junto dos irmãos na Notícia da casa da Cruz ${ }^{122}$.

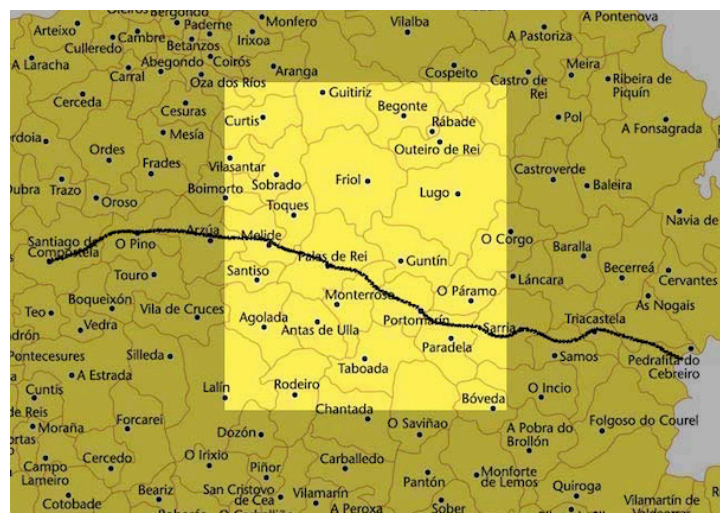

Área de localização das propriedades citadas e Caminho de Santiago na Galiza

113 Este cavaleiro, após a sua morte, deixou ao mosteiro de Vilar de Donas um casal em Vila Nova de Paço (conc. Monterroso?) e uma herdade em Senande (conc. Antas de Ulha) (Novo Cazón 1986: nº 41). No inventário de propriedades de Ferreira, alude-se a essa transação e a outra, ao que parece de conteúdo similar, estabelecida com um Gonçalo Fernandes que poderia ter sido outro filho de Fernando Airas (AHN, Most. de Ferreira de Palhares, 1096, $\mathrm{n}^{\circ}$ 12).

114 AHN, Most. de Ferreira de Palhares, 1090, nº 13 [1265].

115 Souto Cabo 2008, no 109; AHN, Most. de Ferreira de Palhares, 1088, nº 10 [1259].

116 Estes foram: Fernando, Pedro (frade de Meira), Oeiro, Sancha, Maior e Macia Oares (AHN, Cat. de Lugo, 1329D, $\mathrm{n}^{\circ} 9$ [1258]; 1329E, no 6 [1259]; 1329G, no 25 [1260]; 1330A, no 24 [1262]; 1330B, no 14 [1262], 23 [1263]; 1330D, $\mathrm{n}^{\circ} 24$ [1266]; 1330E, no 15 [1267]; 1330F, no 11 [1268]; 1331B, no 18 [1275]).

117 AHN, Ordens Militares, S. Marcos, 393, nº 286 [1270]; Novo Cazón 1986: nº 44.

118 Ela é, muito provavelmente, a Urraca Afonso que, em 1182, estabeleceu um acordo económico com a Sé de Lugo pelo qual esta instituição lhe entregava a igreja de S. Salvador (hoje S. Pedro) de Meixide (Meoseti) -no Caminho de Santiago- (conc. Palas de Rei) e as serviciálias que essa instituição tinha na terra de Ulhoa, recebendo em troca as correspondentes a Vila Tesa e Romariz (Mato, conc. Palas de Rei) (AHN, Cat. de Lugo, 1325G, ${ }^{\circ}$ 13; Fletcher 1978: $\left.n^{\circ} 19\right)$. Sobre o interesse histórico e artístico desta escritura, veja-se Vázquez Castro 1995: 123-140.

119 O documento apresenta alguns problemas na data pela omissão de um "C" e (provavelmente também) de um "I" no numeral. Na datação sincrónica, incluem-se os nomes do bispo de Lugo Ordonho (1218-1226) e do arcebispo compostelano Pedro Moniz (1207-1224).

120 A propriedade situa-se em Coiro (ou Sar de Coiro / Sardecoiro), nas imediações do regato Tago ("In primis per ipso porto de flumine Tago ... et inde per ipso flumine Tago ad portum ubi in primiter incipimus" (AHN, Most. de Ferreira de Palhares, 1082, n 4). Na nota dorsal lemos: "Carta de Coyro de Bisantonya".

121 Um "Rodericus Arias de Aviancos", freire do Hospital, está documentado em 1232 (García Tato 2004: n 66).

122 Na síntese conservada, não se referem posses laicas no arcedianato de Aveancos, às quais se alude no documento citado em relação a Urraca Dias (cf. supra). Elas foram omitidas porque o inventário só tinha como finalidade compilar informações sobre bens de natureza eclesiástica. 


\section{De Hospitale de Pena Godom}

Além do papel dos Monterrosos na promoção da Ordem de Santiago em terras galegas, é muito interessante notar a ligação que mantiveram com o Caminho de Santiago e, em concreto, com um hospital para peregrinos situado naquele ponto em que o concelho de Monterroso converge com o de Portomarim.

O núcleo documental de Ferreira de Palhares do AHN conserva o rol dos depoimentos respeitantes ao contencioso que enfrentava esse mosteiro com os templários de $\mathrm{S}$. Fiz do Ermo (Entrambaságuas, conc. Guntim) sobre a titularidade do vilar de Couso (Ligonde, conc. Monterroso) [D.18 $]^{123}$. Deles, depreende-se que o hospital de Pena Godom ${ }^{124}$ fora edificado por um Pedro Eanes que identificamos com o, já mencionado, pai de Airas Peres de Monterroso $^{125}$. Trata-se de um aspeto altamente significativo pelos vínculos (sociais, económicos e culturais) que sugere com o Caminho de Santiago (cf. infra) e condiz com a projeção territorial da linhagem em questão nas margens desta via.

No conjunto do relato testemunhal encontramos referências a declarações que proferiram três filhos de Airas Peres de Monterroso: Fernando, João e Rodrigo Airas ${ }^{126}$. Uma das testemunhas lembra que Rodrigo Arias afirmava ter ouvido dizer ao pai, Airas Peres, e ao avô que a herdade situada por baixo do hospital pertencia ao mosteiro: "Et dixit Rodericus Arie, filius de dom Arias Petri, et dixit ad abbatem: «Ista hereditas est vestra. Et audivi dicere ad patrem meum et avuolum meum que erat vestra de hospitale ad iusum»»", o que indigita, de novo, Pedro Eanes como o promotor do hospital.

Fernando Airas aparece denominado como "comendador", pelo que supomos chegou a ocupar esse cargo nalguma encomenda santiaguista da zona, talvez em Loio ${ }^{127}$. Neste caso, alude-se a um diálogo com o abade D. Abril ${ }^{128}$, em que esse cavaleiro o aconselhava a povoar "ipsos vilares $<$.. > de tras-lo monte" -localização identificável com o vilar de Couso- em lugar de S. Paio (Ferreira de Palhares, conc. Guntim), para evitar conflitos patrimoniais com ele ou com o conjunto do seu grupo familiar, do qual deduzimos que contava(m) com propriedades na área da freguesia de Ferreira, onde se situa S. Paio, limítrofe com Ligonde ${ }^{129}$.

A intervenção de João Airas, deão lucense, prende-se com o propósito de edificar uma casa pertencente ao hospital de Pena Godom na margem oposta ao local que já ocupava essa instituição no Caminho de Santiago, espaço que já pertencia ao mosteiro de Ferreira ("vilar de Causo erat Ferrarie et veniebat usque Caminum Sancti Jacobi”). Apesar de serem proprietários do Hospital, os Monterrosos manifestaram-se contrários, porque invadia a herdade do mosteiro: "tunc venerunt herderos de Monte Roso et noluerunt ei lexare ibi domum, quod erat hereditas Ferrarie". A testemunha que faz esse depoimento e ainda outra personalizam essa negativa na figura do deão, talvez como representante da família: "quando dixerat ad decanum, dom Johannem Arie, quod facent domum hospitalis sub camino, et ipse noluit quod dixit que erat hereditas Ferrarie" ${ }^{130}$.

123 Reproduzimos apenas os fragmentos de maior interesse [D.18].

124 Veja-se Valdés Blanco-Rajoy 2016. Lembre-se que Vasco Fernandes, um filho de Fernando Airas, vendeu ao mosteiro de Ferreira de Palhares a porção que lhe correspondia nessa instituição assistencial em 1265.

125 Várias testemunhas referem a mudança inicial na localização, de baixo para cima do caminho, já que o espaço inferior era um dos reclamados por ambas as instâncias: "Et audivit dicere de Hospitale de Pena Godom quod tornabit eum, dom Petrus Eanis, de sub camino susu, pro quo dicebant que erat hereditas Ferrarie", "quando entenzara el comendador dompnus Munio cum dom Petro Eanis, tunc dompnus Ramirus dixit quod sciebat, quando dom Petrus Eanis volebat ponere hospitalem sub camino, tunc venit el comendador dom Munio et noluit leyxare facere nihil quod dixit erat suam hereditatem. Et hoc dixit de tempore quod audivit: L annos". Nas duas versões conservadas, o inquérito propriamente dito começa com as referências a Pedro Eanes colecionadas.

$126 \mathrm{O}$ interesse pelo testemunho destes indivíduos deve-se a que várias posses dos Monterrosos ficavam na área em litígio. Este é o caso do Hospital de Pena Godom e da parte mais baixa do vilar de Couso: "vilar de Causo contra cima quod est de Ferrarie et in fundo de erderos" (cf. infra).

127 Neste caso, a identificação dele com o filho de Airas Peres, mesmo sendo muito plausível, é conjetural, já que não há qualquer alusão aos antepassados.

128 Trata-se do abade de Ferreira documentado explicitamente entre 1222 e 1229 . Notemos, contudo, que o seu predecessor, João Eanes, só está registado até 1219.06, e o sucessor deste, João Loução, a partir de 1231.08.15.

129 É de excluir que se trate do comendador dos templários, uma vez que da alocução dele se deduz que o monte Couso pertencia ao mosteiro de Ferreira: "Et audivit dicere quod sempre quod ille mons de Causo erat Ferrarie".

130 Note-se que são dois os episódios em que se refere uma eventual invasão dos terrenos de Ferreira: quando se construía o hospital, por parte de Pedro Eanes, e no momento em que o hospitaleiro decide levantar uma dependência 
Não queremos encerrar esta alínea, dedicada a Airas Peres de Monterroso e aos descendentes dele, sem notarmos uma nova conexão com a linhagem dos fundadores do mosteiro de Ferreira de Palhares ${ }^{131}$. Como foi notado, os sucessores de Airas Peres entregaram à Ordem de Santiago o mosteiro de Vilar de Donas. Ora bem, entre os fundadores dessa milícia inclui-se o nome de Fernando Oares, marido de Teresa Moniz, uma filha de Múnio Pais de Monterroso e de Lupa Peres de Trava ${ }^{132}$. Aliás, um documento do cartulário de Sobrado parece ser um indício do relacionamento de D. ${ }^{a}$ Teresa com a Ordem, mesmo após a morte do marido produzida em 1169. Entre as testemunhas dessa escritura, que reflete a cessão por parte de Teresa Moniz ao mosteiro de Sobrado, em 1175, de uma herdade em Giá (conc.

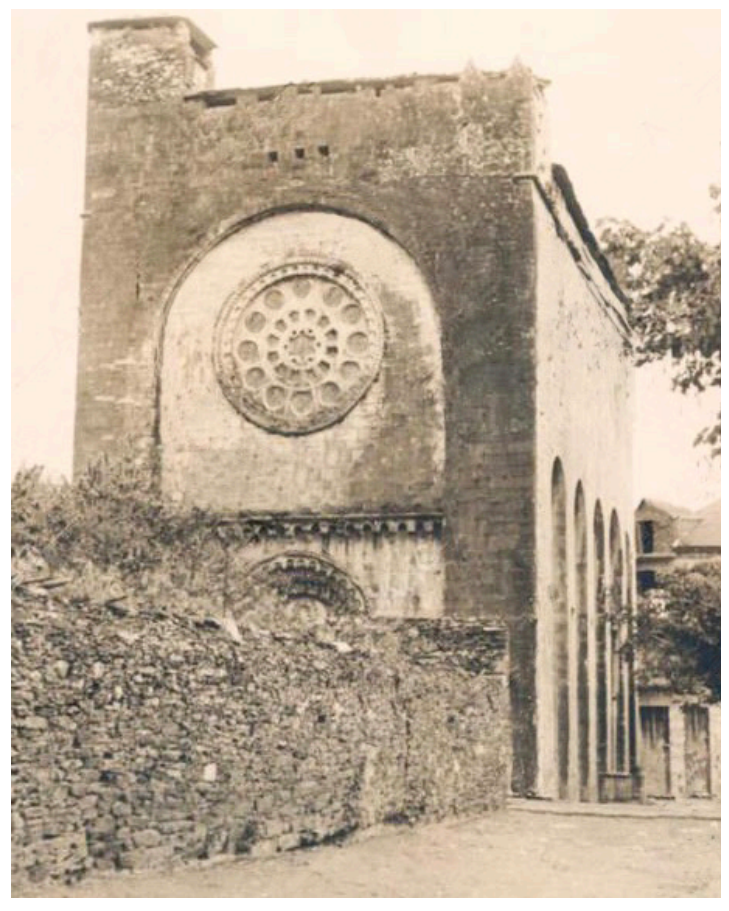

Igreja de S. Nicolau no velho Portomarim (Foto Blanco)
Friol), deparamos com um "Petrus Sancii, miles Caceris" (Loscertales 1976: II, no 369); isto é, um membro da Ordem de Santiago, que nos seus inícios foi conhecida como "Ordem de Cáceres".

\section{Unum quinionem de Petro Odoarii}

Como vimos, logo a seguir aos filhos de Airas Peres, encontrávamos a referência à porção da casa que correspondera a Marina Peres, transmitida à Sé lucense por Pedro Oares e Marina Oares. Como cabia esperar pela coincidência no patronímico, estamos perante uma filha de Pedro Eanes de Monterroso -irmã de Airas Peres-e dois filhos dela, tal como vem confirmado num diploma de 1195 em que esse Pedro Oares vendia ao bispo de Lugo uma casa em Portomarim que tinha pertencido a esse avô, referindo ao mesmo tempo os nomes da mãe e da irmã [D.1]:

ego, Petrus Odoarii, vobis domno Ruderico Secundo lucensi episcopo, libenti animo nullo cogente vel suadente, facio cartam venditionis medietatis unius quinte $\langle\ldots>$ case que fuit domni Petri Johannis de Monte Roso, que est in Portumarin, in parte Sancti Nicholai, que casa est in fronte ipsius Pontis Minei, inter casam que fuit Munionis Papin et casam que fuit domni Cristofori. Et habui eam ex sucessione avi mei, prefati Petri Johannis de Monte Roso, et matris mee, Marine Petri, et de ganancia de sorore mea Marina Odoarii.

A identificação doutras pegadas documentais desse Pedro Oares enfrenta, como veremos, algumas dificuldades ${ }^{133}$. Poderia tratar-se do cavaleiro que esteve casado com uma Teresa Afonso e de quem conhecemos os filhos seguintes: Airas, Godefreus, Gonçalo, Maior e Sancha Peres. Por uma escritura de 1240, em que se alude a ele como já falecido, a mulher e os filhos vendiam a Múnio Fernandes de Rodeiro uma herdade em Cas Sendino, na freguesia

anexa. Valdés Blanco-Rajoy (2016: 210), por não ter identificado esses dois momentos, situa Pedro Eanes em tempos do deão João Airas: "El caso es que Pedro Eanes construyó en tiempos del deán de Lugo Juan Arias la casa de un hospital en Pena Godón".

131 A historiografia fabulosa estabeleceu um nexo entre os Gaiosos, Monterrosos e fundadores de Ferreira de Palhares, mas não é possível descobrirmos alguma verdade histórica nessas informações (Coira Sanjurjo 2012: 446-451).

132 Sobre o relacionamento de Fernando Oares com essa instituição, vejam-se, entre outros, Martín 1974: 18, n. 39; 118, n. 226 e Souto Cabo 2012: 90-92. Pedro Tinha, frade e comendador de Vilar de Donas, registado nos mais antigos documentos dessa instituição (Novo Cazón 1986, n 1 [1194], 2 [1196]), era tio de Pedro Oares (Souto Cabo 2012: 88-90).

133 Quanto à irmã, Marina Oares, ela é certamente a "domne Marine Odoarii” que, em 1212, entregava ao bispo de Lugo o que lhe pertencia na igreja de S. Julião de Campo (conc. Taboada), recebendo do prelado em prestimónio um casal nessa mesma freguesia durante a vida dela, da filha Maior Moniz e do neto Adão Airas (AHN, Cat. de Lugo, 1326F, n 12). 
de Mourulhe (conc. Taboada), o que nos situa apenas a 3,5 km de Giám, na mesma margem do Minho ${ }^{134}$. Essa localização repete-se no ato documental pelo qual duas das filhas, Sancha e Maior Peres (com os respetivos maridos: Nuno Eanes e Paio Garcia), entregavam em 1278, por venda outorgada em Portomarim, ao mosteiro de Ferreira propriedades no vilar de Cas Sendino e em Olveda nessa mesma freguesia ${ }^{135}$.

É de grande interesse o diploma pelo qual Gonçalo Peres, outro filho de Pedro Oares, doou à Sé de Lugo, em 1256, os quinhões que possuía em diversas igrejas ${ }^{136}$. Em concreto, menciona as oito seguintes: S. João de Loio (conc. Paradela), S. Mamede [de Velade (?) (conc. Portomarim) $]^{137}$, Cortapezas (conc. Portomarim), S. Julião de Recelhe (conc. Portomarim), S. Mamede de Rio (conc. Portomarim), Hospital da Cruz (Rio, conc. Portomarim) ${ }^{138}$, Casdanaia (conc. Antas de Ulha), Ponte do Arcediago (Arcediago, conc. Santisso) ${ }^{139}$. Como vemos, o conjunto de benefícios eclesiásticos referidos situa-se na área do Caminho de Santiago que se estende desde o rio Minho até ao Furelos, portanto, em espaços em grande medida coincidentes com aqueles em que se localizavam as posses de Gontrode Rodrigues e dos Monterrosos. Entre os pontos de convergência, encontra-se, de modo recorrente, a vila de Portomarim e, no seu entorno, a freguesia de Recelhe, a que aparecem associados todos os ramos da linhagem.

O Pedro Oares (da Sardinheira) citado nos parágrafos anteriores não é o único cavaleiro desse nome associado a Portomarim durante as primeiras décadas do séc. XIII. Como se sabe, essa vila foi cabeça da encomenda mais importante da Ordem de S. João de Jerusalém na Galiza, a milícia mais galega de todas as que se instalaram no país ${ }^{140}$. Ora bem, o que foi comendador e prior dessa Ordem nos reinos da Galiza e Leão -e ainda no conjunto dos reinos peninsulares-entre 1209 e 1233 recebia também a denominação de "Pedro Oares"141. Os mais antigos registos dele, no exercício dessa função, são de fevereiro de 1209 quando testemunhava dois documentos outorgados por Afonso IX em Sobrado e Portomarim. No segundo, o monarca deu ao mosteiro de Ferreira de Palhares a vila de Nespereira (conc. Portomarim), contando com a presença de "Domno Petro Oariz comendatore hospitalis in regno legionis"142. Entre os diversos atos documentais em que participa, como comendador e prior "in tribus regnis Hispanie", encontra-se a concessão de carta foral a Portomarim em 1212, vila cuja jurisdição fora doada à Ordem pelo monarca citado. Em princípio, o carácter celibatário que esperaríamos na figura do prior dificulta a sua identificação com o cavaleiro casado com Teresa Afonso, salvo se pensarmos no abandono da vida conjugal para ingressar na Ordem, uma vez que a mulher lhe sobreviveu. Se foram pessoas diferentes, não temos elementos que nos permitam optar, claramente, por um deles como neto de Pedro Eanes de Monterroso ${ }^{143}$.

\section{Monio Fernandez de Mirapeyxe}

Após a aproximação efetuada aos diversos grupos de parentes que acompanham Múnio Fernandes de Mirapeixe na Notícia da casa da Cruz, viramos agora a nossa atenção para a figura do trovador. O seu nome surge na

134 AHN, Most. de Ferreira de Palhares, 1085, $\mathrm{n}^{\circ} 5$.

135 O pai é nomeado como "domni Petri Odoarii qui fuit de Sardineyra" (AHN, Most. de Ferreira de Palhares, 1093, $\mathrm{n}^{\circ}$ 18, 19 [1278]). A terra medieval de Sardinheira, cuja denominação remonta ao curso de água homónimo, correspondia a uma área do atual concelho do Savinhao limítrofe com os de Chantada e Taboada. Um Pedro Oares testemunhava, em 1210, um ato documental pelo qual o mosteiro de Vilar de Donas arrendava a igreja de S. João de Antas (conc. Antas de Ulha): "Petrus Odoarii, miles, testis" (Novo Cazón 1986: nº 3).

136 Ele não figura entre os filhos de Pedro Oares e de Teresa Afonso, o que nos leva a pensar que foi fruto de um casamento anterior, mas não se pode duvidar que foi prole desse cavaleiro: "eu Gonzalvo Petri, filo que foi de Pedro Hourez de Sardinneira". Veja-se a nota anterior.

137 Pensamos que poderia tratar-se da igreja de Velade que, junto com a de Rio, tem como orago S. Mamede.

138 Como se deduz do nome, nessa aldeia situava-se um antigo hospital para peregrinos.

139 AHN, Cat. de Lugo, 1329A, nº 28; Souto Cabo 2008, nº 59.

140 Ela potenciou o Caminho de Santiago e utilizou-o como via para a expansão nos reinos da Galiza, Leão e Castela: "Dentro de este proceso debemos insertar su aparición en Portomarín, una de las etapas importantes de la ruta jacobea por tierras gallegas" (Barquero Goñi 1999: 91). Sobre a presença dessa Ordem na Galiza veja-se também García Tato 2004.

141 Ayala Martínez 1995: no 201 [1209], 206 [1211], 208 [1212], 218 [1216], 222 [1217], 229, 231 [1220], 232, 233 [1221], 247 [1228], 261 [1232], 262 [1233].

142 AHN, Most. de Ferreira de Palhares, 1082, nº 23. 
camada mais antiga da tradição manuscrita, isto é, o segmento inicial da secção que foi denominada "cancioneiro de cavaleiros" (Oliveira 1994: 179-181). O conhecimento deste grupo de autores revelou-se chave para definir o contexto em que germinou e se desenvolveu inicialmente o lirismo trovadoresco nas terras do noroeste peninsular. Como está provado, reúne de modo quase exclusivo membros da aristocracia galega pertencentes ou, de algum modo, associados a algum dos ramos da linhagem dos Travas ${ }^{144}$. Nesse primeiro sector, Múnio Fernandes ocupa a undécima posição, precedido por Osório Eanes (1175-1217), Airas Oares (1187), Rui Dias dos Cameros (1182-1226) e Pedro Rodrigues da Palmeira (1225); sendo seguido -se excetuarmos Fernão Figueira de Lemos (cf. infra)- por Gil Sanches

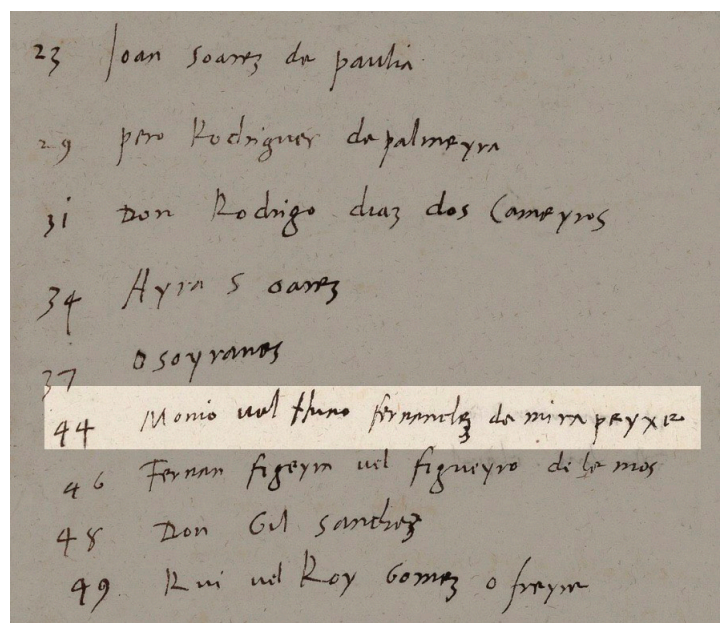

Tavola Colocciana (fl. 300v)
(1207-1236), Rui Gomes o Freire (1215), Fernando Rodrigues de Calheiros (1195) e Pedro Garcia de Ambroa (1203-1235) ${ }^{145}$.

Salvo Gil Sanches, estamos perante poetas que terão atingido a maioridade ainda no séc. XII. Nesse sentido, é pertinente notar que Osório Eanes e Rui Dias dos Cameros exerciam atividade política, pelo menos, em 1187 e 1186, respetivamente (Souto Cabo 2012: 117, $170)^{146}$. A integração de Múnio Fernandes de Mirapeixe num contexto cronológico similar não é desmentida, antes pelo contrário, por aquilo que podemos deduzir, sobretudo, dos registos documentais de Gonçalo, Pedro (I) e Rodrigo Fernandes de Mirapeixe, ou ainda dos relativos aos filhos deste último.

Como vimos, o único documento em que surge o nome de Múnio Fernandes de Mirapeixe é o inventário, por grupos, dos indivíduos que entregaram à Sé lucense a posse de um imóvel na rua da Cruz com a indicação dos proprietários prévios. O autor material do texto foi Fernando Pais, "Fernandus Pelagii, notarius lucensis", cónego e notário de Lugo entre 1235 e $1265^{147}$. O seu nome aparece associado ao processo de organização da documentação custodiada no arquivo da Sé de Lugo em tempos do bispo D. Miguel (1226-1270) e, em concreto, aos cuidados para preservar o legado documental pretérito ${ }^{148}$. Fernando Pais subscreve utilizando a forma verbal "transcripsit", termo a que recorre ${ }^{149}$ quando traslada um original preexistente, que, por algum motivo, se julgou necessário reproduzir ${ }^{150}$. No entanto, aquilo que lavra Fernando Pais não é

143 Como foi notado, pelo menos, dois membros da linhagem poderiam ter mantido algum tipo de relacionamento com a Ordem: Marina Pais e Rodrigo Airas (cf. supra). A homonímia característica do período não permite certezas ao respeito.

$144 \mathrm{O}$ meu entendimento das origens do fenómeno trovadoresco vê-se refletido em Souto Cabo 2012, 2016, 2018a. Veja-se também Brea 2016.

145 Além de Múnio Fernandes de Mirapeixe e dos irmãos Taveirôs, Pedro Garcia de Ambroa é o poeta que parece ter mantido vínculos sociais mais evidentes com Rodrigo Gomes de Trava. Veja-se Vieira 1999: 111-114 e Souto Cabo 2006. A nossa perspetiva sobre as informações relativas a esse poeta tem-se modificado parcialmente. Hoje pensamos que todos os registos históricos em que figura "Pedro Garcia de Ambroa" devem ser atribuídos ao trovador documentado, em vida, entre 1203 e 1235.

146 Osório Eanes e dois dos seus irmãos surgem nesse ano como tenentes da Castela ourensana "princeps Castelle: Petrus Johannes et Goncialvus Johannes et Osorio Johannes" (AHN, Most. de Osseira, 1511, n 3; Romaní Martínez 1989: $n^{\circ} 73$ [1187.10.18]). Quanto a Rodrigo Dias, ele testemunha um diploma de Afonso VIII de Castela outorgado em Ágreda (Soria): "Rodericus Didaci, conf.” (González 1960: no 448 [1186.01.16]).

147 Posteriormente -e até inícios da década de 70- ele figura na qualidade de "vice-notário".

148 "Fernandus Pelagii comenzará la tarea de transcribir, copiar y autentificar otros documentos importantes de épocas más antiguas que se suponen de alto interés y utilidad práctica para la diócesis" (Mosquera Agrelo 2002: 933). Veja-se: AHN, Cat. de Lugo, 1325B, no 1, 2, 23; 1325C, $\mathrm{n}^{\circ} 24,25 ; 1325 \mathrm{G}, \mathrm{n}^{\circ} 11 ; 1325 \mathrm{H}, \mathrm{n}^{\circ} 15$ etc.

149 Em lugar do habitual -por extenso ou abreviado-notavit.

150 Com esse mesmo sentido, também se vale de transtulit ou exemplavit. Nalguns casos alude explicitamente à existência de um original. 
um diploma dispositivo ${ }^{151}$; antes podemos falar de um escrito de natureza probatória -uma "notícia"- destinado a registar e perpetuar, em última instância, o resultado do ato jurídico (oral ou escrito) pelo qual a Sé de Lugo obteve a posse do prédio em questão ${ }^{152}$. A ausência de documento dispositivo pode ser explicada porque ele nunca existiu, com essa natureza, ou então porque desapareceu ou sofreu deterioração que o tornou irrecuperável ${ }^{153}$. Como quer que seja, devemos supor que se chegou, obviamente, àquela fase em que todos os proprietários do imóvel manifestaram a sua vontade de o entregar à Sé. Para situar esse evento no tempo e estabelecer, em primeiro lugar, um limite ante quem, o dado fundamental é constituído pelo falecimento de Aldonça Rodrigues de Bacurim em 17 de abril de 1201 (cf. supra). Quanto ao limite post quem, se aceitarmos que Lupa Rodrigues foi a mãe dos cavaleiros de Mirapeixe citados e ela for identificada com a personagem homónima citada em $L A$, então a baliza inferior situar-se-á em 22 de janeiro de 1192, dia em que morreu essa senhora. A cronologia que, para Múnio Fernandes de Mirapeixe, se deduz desse dado coaduna-se com o que conhecemos sobre outros doadores, como João Airas, Fernando Airas, Diogo Airas ou Pedro Oares, indivíduos que terão chegado ao fim da vida nas três primeiras décadas do séc. XIII.

Como vimos, na versão expandida (e definitiva) do testamento de Teresa Fernandes omite-se o apelido "de Mirapeixe", que caracterizava a titular e dois dos seus irmãos na primeira versão. Ora, se esta última não se tivesse preservado teríamos grandes dificuldades para identificar os indivíduos nela presentes como pertencentes à linhagem do poeta. Com efeito, a atribuição do sobrenome linhagístico na denominação de um indivíduo é uma prática em expansão na primeira metade do séc. XIII, mas que está longe de ser sistemática. Portanto, é possível que a presença do trovador na documentação se tenha visto, em boa medida, camuflada pela ausência de patronímico, tal como sugere Ron Fernández (2015: 644): "Non resulta doado achegar datos certeiros sobre este trobador, debido a que, seguramente, comparece na documentación sen o locativo identificativo, e a combinación Munio Fernandi é bastante frequente". Este estudioso sugere, assim, identificá-lo com "o Munio Fernandi que exerce de prestameiro en terra de Prucis [1206]" ou com "o Munio Fernandi que sae num documento protagonizado polo conde don Fernando de Lara [...] onde ao carón dun Fernandus Nuni de Parrega miles sae un Munio Fernandi [1208]". Consideraremos, ordenadas em sequência temporal, outras identificações históricas plausíveis para o trovador em estudo ${ }^{154}$.

Os mais antigos registos documentais dos irmãos de Múnio Fernandes de Mirapeixe evidenciam, como vimos, uma associação ao grupo familiar Rodrigo Gomes de Trava (12011261), certamente na qualidade de subordina$\operatorname{dos}^{155}$. Com efeito, Rodrigo e Garcia aparecem de modo recorrente -e em sequência- como confirmantes em documentos de interesse para o magnate galego $[\mathrm{D} .6,7,9,10,11]$. Por sua vez, Rodrigo já nos aparecera com essa função

151 Isto é, aquele que consubstancia um ato jurídico e cuja aceitabilidade pública decorre da acomodação a pautas diplomáticas e escriturais fixas.

152 Conhecemos um documento (nalguns aspetos) semelhante em que se inventariam os quinhões que pertenciam à Sé de Lugo na igreja de Santa Marta ("Isti sunt quiniones quos habet Lucensis ecclesia in ecclesia de Sancta Marta", AHN, Cat. de Lugo, 1331H, n 29).

153 É importante notar que não temos nenhum outro rasto documental relativo a essa transação patrimonial, nem no rico fundo de pergaminhos da Catedral de Lugo nem nos Livros de Aniversários, o que, desde logo, afasta a possibilidade de estarmos perante uma espécie de súmula de atos documentais independentes.

154 O diminuto elenco de nomes pessoais utilizados na altura, com o alto grau de homonímia que disso se segue, constitui uma notável dificuldade para discriminar indivíduos. Por outro lado, como notou Pardo de Guevara (2009: 32), na descendência do enlace entre Teresa Moniz e Fernando Oares veio a tornar-se frequente a associação "Múnio Fernandes", como observamos em vários membros da estirpe dos Rodeiros, colocando uma armadilha às tentativas de identificar o trovador. Contudo, a presença, não rara, do apelido linhagístico "Rodeiro" para os membros dessa parentela serve, ocasionalmente, para evitar confusões.

155 Sabemos que Rodrigo Gomes de Trava tinha interesses patrimonais na cidade de Lugo (AHN, Cat. de Lugo, $1328 \mathrm{G}, \mathrm{n}^{\circ} 14$ [1253]), urbe a que aparecem fortemente associados os Mirapeixes.

156 López Sangil (2005: 163) atribui-lhe, sem apoio documental, a dignidade condal, mas o seu nome não aparece no grupo de "counts of León and Castile" de Barton (1997). Apesar de este investigador britânico não o ter incluído entre os filhos de Gonçalo Fernandes de Trava, essa filiação parece muito plausível. Veja-se Bermúdez Beloso 2017: 481-483. Rodrigo Gonçalves chegou a exercer como "tenente Galicia” (AHN, Most. de Penamaior, 1215, $\mathrm{n}^{\circ}$ 2; Fernández de Viana 1971: nº 10 [1206]). 
numa escritura de 1225 [D.5] da qual é titular Rodrigo Gonçalves (1202-1226), tio paterno de Rodrigo Gomes ${ }^{156}$. O relacionamento em questão poderia remontar ao pai de Rodrigo Gomes, o conde Gomes Gonçalves de Trava (1164-1211), aliás irmão desse Rodrigo Gonçalves. D. Gomes foi uma das personalidades mais distinguidas nas cortes de Fernando II e Afonso IX, de quem chegou a ser mordomo em 1193. Ele exerceu como tenente sobre algumas das mais importantes entidades territoriais galegas, entre elas: Montenegro, Monterroso, Sárria ou Trastâmara ${ }^{157}$. O poder do conde também se evidencia na configuração de um círculo curial próprio, com mordomo e alferes, similar ao régio ${ }^{158}$. Ora bem, numa escritura inédita de 1186.05 .17 , pertencente ao núcleo documental do mosteiro de Cis (conc. Oça dos Rios) ${ }^{159}$, a confirmação do conde é seguida pela do seu mordomo de nome Múnio Fernandes: "Gometius, comes in Transtamare, confirmat. Munio Fernandi, maiordomus comitis, confirmat" ${ }^{160}$. Levando em linha de conta os antecedentes citados, não podemos descartar que se trate do próprio Múnio Fernandes de Mirapeixe ${ }^{161}$, o que seria altamente significativo e viria, de algum modo, condizer com as propostas que explicam a participação do autor no movimento poético através dos seus vínculos com Rodrigo Gomes ${ }^{162}$.

A segunda proposta, já difundida noutro trabalho (Souto Cabo 2018a: 22-24), permite relacionar Múnio Fernandes de Mirapeixe com outro dos mais vetustos representantes do nosso lirismo medieval, Rodrigo Dias dos Cameros. Numa escritura lavrada em 5 de dezembro de 1199 [D.2], o cavaleiro Múnio Fernandes vendia à Sé de Lugo propriedades em Cambra (Campo, conc. Lugo) que recebera de Guiomar Rodrigues de Trava (1162-1199) pelos bons serviços que fizera a esta dama, o que parece apontar para um vínculo de parentesco e/ou dependência. Como se faz notar, a cessão da herdade por parte dessa dama contou com a anuência de três filhos dela, entre eles a de Rodrigo Dias dos Cameros:

ego Munio Fernandi, miles, bono animo et sana voluntate, vobis domno Ruderico lucensi episcopo et ecclesie vobis conmisse, facio cartam venditionis tocius hereditatis de Camera cum omni iure suo, quam michi hereditario iure dedit et concessit domna Giumar, pro bono servitio quod sibi feci, concedentibus Ruderico Didaci, et Alvaro Didaci et Enego Didaci filiis suis.

Um Rodrigo Fernandes "miles" comparece como primeira testemunha da compra-venda citada. $\mathrm{O}$ posto de destaque que ocupa na lista das testemunhas e a coincidência no patronímico sugerem que podemos estar perante um irmão do vendedor, reforçando assim a possibilidade de se tratar de Múnio e Rodrigo Fernandes de Mirapeixe ${ }^{163}$.

157 Veja-se também Bermúdez Beloso 2017: 477-481. Por motivos desconhecidos, perdeu o favor real e foi expulso do reino entre 1198 e 1204.

158 "Se nos presenta así con claridad la existencia de una compleja estructura de poder y de una verdadera corte señorial o nobiliaria de cierta sofisticación, que emula en su funcionamento, por la presencia de cargos como mayordomo, alférez o notario, la composición de la propria corte real" (Varela Cajide 2017: 331).

159 Lucas Álvarez (1999: 1038) indica que se trata de um documento "muy deteriorado e ilegible", o que não corresponde totalmente à realidade. É provavelmente por esse motivo que terá sido excluído da edição dos fundos documentais do mesmo (Lucas Álvarez 2004). Por ele, o abade D. Múnio de Cis vendia a D. Fernando, abade de Sobrado, o Agro do Moinho.

160 AHN, Most. de Cis, 494, $\mathrm{n}^{\circ}$ 14. Ele acompanha o conde, pelo menos, até 1187, segundo se comprova por dois diplomas do mosteiro de Ferreira de Palhares em que ambos são testemunhas (AHN, Most. de Ferreira de Palhares, $\left.1082, n^{\circ} 15,16\right)$.

161 Como foi notado, o grupo familiar deste último caracteriza-se por ter estabelecido nexos parentais com membros de estirpes catalano-provençais, portanto, da área em que se originou o trovadorismo poético. Referimo-nos, por um lado, a Miracle de Urgell, uma filha de Armengol VII de Urgell e de Dulce de Foix, que foi mãe de Rodrigo Gomes; por outro, a Berengária, sobrinha do próprio Raimundo Berengário IV (conde de Barcelona e rei de Aragão) e segunda esposa de Gonçalo Fernandes de Trava, de quem Gomes Gonçalves foi, portanto, enteado. Veja-se Souto Cabo 2012: 201-205; 2018: 15-16.

162 Não parece que possa ser identificado com Múnio Fernandes de Rodeiro (I), cavaleiro que foi primeiro mordomo de Afonso IX em 1188, portanto muito antes que esse posto fosse ocupado pelo próprio Gomes Gonçalves.

163 Guiomar Rodrigues foi filha de Rodrigo Peres o Veloso de Trava e de Fruilhe Fernandes de Celanova. Além do vínculo paterno com os Trava, é importante reter que D. ${ }^{a}$ Fruilhe se integra, por via materna, na linhagem dos fundadores do mosteiro de Ferreira de Palhares (cf. supra), cenóbio ao qual entregou, em 1187, por dois atos documentais, propriedades em Entrambaságuas (conc. Guntim). Trata-se dos diplomas, antes citados, confirmados por 
No último ato documental conhecido de Teresa Moniz (1164-1210) -filha de Múnio Pais de Monterroso e de Lupa Peres de Trava (cf. supra)-, esta senhora atribuía, em 1210, a um "soprino" de nome Múnio Fernandes a incumbência de devolver ao mosteiro de Ferreira de Palhares propriedades em Macedo (Condes, conc. Friol) e em Samai (Entrambaságuas, conc. Guntim) ${ }^{164}$. Esse sobrinho terá sido filho de um Fernando Moniz, irmão dessa senhora, a que se alude, retrospetivamente, numa escritura de 1241, por ter doado ao mosteiro de Ferreira de Palhares uma herdade em Serviám (conc. Guntim): "domni Fernando Munionis, qui fuit filius comitis domni Munionis" ${ }^{\prime 165}$. Neste caso, o eventual reconhecimento do poeta no sobrinho de Teresa Moniz também implicaria resolver o enigma da identidade do pai dos Fernandes Mirapeixe ${ }^{166}$.

No documento em que Fernando Airas, um filho de Airas Peres de Monterroso, vendia ao bispo de Lugo, em 1226, uma casa em Portomarim, fazia-se constar que ele era "frater milicie Sancti Jacobi". De acordo com outras informações sabemos que chegou a ser comendador, provavelmente na encomenda de Loio (cf. supra). Ora bem, entre os indivíduos que confirmam esse escrito, encontra-se um "Munio Fernandi subcomendator", que também associamos à administração dos Santiaguistas em Loio ${ }^{167}$. A identificação dele com o poeta vê-se favorecida pelo contexto familiar em que se produz ${ }^{168}$, e viria ao encontro da eventual integração nessa Ordem doutros dois nomes da geração mais antiga de trovadores da lírica galego-portuguesa: Pedro Pais Bazaco e João Soares Somesso ${ }^{169}$.

\section{Desejos perder e sabor}

A tradição manuscrita da lírica galego-portuguesa preservou apenas (no Cancioneiro da Biblioteca Nacional) duas cantigas sob o nome de Múnio Fernandes de Mirapeixe, Pois me fazedes, mia senhor (B 44) e Dizer-vos quer' eu, mia senhor (B 45), como únicos restos do que deverá ter sido uma produção poética mais extensa ${ }^{170}$.

Na primeira composição o sujeito poético explica, logo nas estrofes iniciais, como a inexorável falta de correspondência amorosa resulta na perda de interesse por seja o que for. Aliás, ciente da natureza fatal dessa paixão, só a morte se lhe afigura como via de saída:

\author{
Pois me fazedes, mia senhor, \\ de quantas cousas no mund'á, \\ desejos perder e sabor, \\ senon de vós, de que eu ja \\ nunca desejos perderei, \\ nen al nunca desejarei \\ no mundo senon vós, senhor,
}

ou mia morte; poix me vós ben, senhor, non queredes fazer, ca non á no mund' outra ren

Gomes Gonçalves e Múnio Fernandes. D. ${ }^{a}$ Fruilhe contava com propriedades em S. João de Campo, segundo se reflete no ato documental pelo qual vendia, em 1162, uma herdade nessa freguesia a Elvira Moniz (AHN, Cat. de Lugo, $\left.1325 \mathrm{E}, \mathrm{n}^{\circ} 1\right)$.

164 AHN, Most. de Ferreira de Palhares, 1082, no 24. Monteagudo (2008: 352, n. 23) chegou a exprimir algumas dúvidas sobre a data do escrito, por considerar que a titular era a esposa de Paio Moniz de Refronteira, mas ela foi mulher de Fernando Oares.

165 AHN, Cat. de Lugo, 1328A, nº 18.

166 Teresa Moniz teve um neto de nome "Múnio Fernandes de Rodeiro" a quem, por lapso, atribuímos a localização cronológica "1210-1261" (Souto Cabo 2012: 92), em lugar da correta “1229-1261”. Sobre os possíveis vínculos com o trovadorismo desse cavaleiro e da primeira mulher, Constança Martins, veja-se Souto Cabo / Vieira (2003: 232-234). De modo mais genérico, Monteagudo (2008: 333-339) também considera as ligações do de Rodeiro com os trovadores.

167 AHN, Cat. de Lugo, 1327C, nº 5.

168 Lembremos, aliás, o relacionamento de Teresa Moniz e do marido, Fernando Oares, com a Ordem de Santiago (cf. supra).

169 Como se sabe, um "I. Sumesso", identificado com este trovador, surge entre as testemunhas de um documento de Vilar de Donas; o que foi interpretado como indício da integração dele na instituição santiaguista (Souto Cabo 2012: 132, 161). Veja-se também Monteagudo 2014: 108-113.

170 Vieira $(2004,2005)$ analisou do ponto conceptual as duas cantigas, sublinhando a proximidade ao discurso escolástico e teológico da cultura clerical da época. Nesse entendimento, relaciona a obra de Múnio Fernandes de Mirapeixe com o "grupo de poetas que circularam à volta de Santiago de Compostela" nos quais a linguagem culta se ressente "do contacto próximo com as práticas intelectuais escolásticas então prestigiosas, seja em ambiente clerical propriamente dito, como nos sermões, seja em situações mais mundanas" (Vieira 2005: 749). Entre eles, inclui trovadores ligados a Rodrigo Gomes, como Paio Soares, Pero Velho de Taveirôs, Pero Garcia de Ambroa ou Nuno Rodrigues de Canderei (Ibid.: 747). 
por que eu ja possa perder a coita que eu por vós ei senon por morrer, eu o sei, ou por min fazerdes vós ben, [...] (vv. 1-14)

Para exprimir a indiferença que passou a sentir por tudo o que há no mundo, Múnio Fernandes de Mirapeixe serve-se do verbo "perder" complementado por "desejos" e "sabor". O uso deste último substantivo, associado àquele verbo em contextos significativos semelhantes, só está presente noutros quatro poetas da escola ${ }^{171}$. A expressão foi especialmente grata ao insigne Nuno Eanes Cêrcio -trovador, por vários motivos, próximo do Mirapeixe ${ }^{172}$, que a utiliza em duas cantigas: "perdud" ei por vós já o coraçon / e sabor do mundo que soia eu aver", "de mi / que vós fezestes perder do mundo sabor" (Senhor, perdud' ei por vós já o coraçon); "de tod' al do mund', ei perdudo sabor" (Toda-las gentes mi a mi estraias son ${ }^{173}$ ). Também a registamos em Vasco Gil de Soverosa: "des quando vos amei / todo sabor do mundo perdud' ei / e non mi ar pude d' outra ren pagar/ senon de vós" (Sennor fremosa, pois m'oj'eu morrer) e em Vasco Peres Pardal: "e ja perdud' ei / de quant' al avia sabor" (Senhor, des quand'en vós cuidei ${ }^{174}$ ). No entanto, a convergência dessa ideia -nos termos semânticos descritos- com a referência à morte, tal como a víamos em Mirapeixe, só se repete na cantiga Ai mia senhor, sempr'eu esto temi (B 46), que figura sob autoria de Fernão Figueira de Lemos ${ }^{175}$ :

\section{$[\ldots]$}

Ca vos vi por meu mal, mia senhor, por vos aver ja sempr' a desejar, e perdud' ei gasalhad' e sabor de quanto al no mundo soia amar: tod' esto mi vós fezestes perder! Fez-me-vos Deus, por meu mal, ben querer!
Por meu mal foi, pois que vos ja sempr' eu averei ja eno meu coraçon a desejar, e nunca mais do meu cor perderei mui gran coita que non veerei ren que mi possa plazer ergo se vir a min por vós morrer. (vv. 13-24)

Como vemos, as duas cantigas compartilham a existência de um outro complemento direto para "perder", além de sabor: "desejos perder e sabor" e "perdud' ei gasalhad' e sabor", estrutura sintática que não voltamos a encontrar. Noutros aspetos da linguagem literária também descobrimos afinidades entre esses poemas. Assim, a rima derivada perderei-perder (I.5, II.4), a associar a primeira e segunda estrofes da cantiga de Múnio Fernandes, encontra correspondência em perder-perderei (I.6, II.1) presente nessas mesmas sequências estróficas da canção atribuída ao de Lemos ${ }^{176}$. É ainda de assinalar a proximidade no início das terceiras cobras: "ca me fazedes muito mal / des aquel dia'n que vos vi" e "Ca vos vi eu por meu mal, mia senhor", a presença de "meu mal" no verso final dessas mesmas unidades ${ }^{177}$ : "e farei meu mal" (III.7), "Fez-me-vos Deus, por meu mal, ben querer" (III.6), e a combinação de "pois" e "ja" nos primeiros versos das últimas estrofes: "e faça-[o] ja, pois Deus quer" / "Por meu mal foi, pois que vos ja sempr'eu" (IV.1) ${ }^{178}$. A aparente relação de intertextualidade que existe entre as composições em questão pode ganhar um novo significado se levarmos em linha de conta que concerne a cantigas praticamente contíguas -separadas apenas pelo texto fragmentário citado- e que a presença do Lemos nesse ponto resultou de uma intervenção secundária.

Sob a rubrica "Fernan Figeyra / Figueyro de Lemos" encontramos duas composições, aquela citada no parágrafo anterior e a cantiga

171 Quanto à combinação "perder + desejos", só reaparece em Pero vejo donas ben parecer de Bernal de Bonaval: "cuidando, perdi / desejos de quant' al fui amar".

172 Veja-se Souto Cabo 2018b.

173 O termo "sabor" ocorre de novo nessa mesma cantiga como complemento do verbo "achar" ("En nen ũa terra non poss' eu achar / sabor sen vós"), portanto, com um significado, em parte, diferente.

174 Trata-se do primeiro verso do dístico que constitui o refrão, pertencendo as formas do verbo "perder", de que depende, ao verso anterior ("perdud' ei", "perdi”, "perdi des enton").

175 Nuno Eanes Cêrcio, na primeira das cantigas citadas, afirma sentir prazer por uma eventual morte ("praz-mi con mia morte"), mas essa possibilidade não é apresentada como alternativa à perda de "sabor do mundo".

176 Além dos textos em questão, o uso de perder-perderei como rima derivada aparece em João Soares Somesso, Martim Soares (2), Osório Eanes, Pero Garcia Burgalês, Rui Gomes o Freire e Vasco Praga de Sandim (3), mas só em duas composições deste último é que afeta as estrofes primeira e segunda.

177 Na cantiga do Mirapeixe, mal constitui palavra-rima.

178 Para além das diferenças no número de sílabas e versos, deparamos com estruturas rimáticas muito similares: 4x 8a $8 \mathrm{~b} 8 \mathrm{a} 8 \mathrm{~b} 8 \mathrm{c} 8 \mathrm{c} 8 \mathrm{a}$ (B 44) e 4 x 10a 10b 10a 10b 10c 10c (B 46). 
de amigo Diz meu amigo que lhe faça ben (B 47), de que só se conserva a primeira estrofe. Esta composição representa a primeira perturbação à tripartição de géneros na tradição manuscrita, já que nos encontramos no interior da secção, em origem, reservada às cantigas de amor. De acordo com Oliveira (1994: 90, 338339), a localização da obra do de Lemos em B terá resultado do aproveitamento tardio de um espaço "em branco para a inclusão da sua obra nas compilações colectivas". A hipótese vê-se apoiada pela identificação do autor com o homónimo registado em terras portuguesas entre 1258 e 1285, portanto, num âmbito cronológico muito posterior ao dos autores da zona da tradição manuscrita em que veio a ser inserido (cf. supra $)^{179}$. Dado que não existem motivos que justifiquem, ao mesmo tempo, a improvável proximidade material e poética que achamos entre Pois me fazedes, mia senhor e Ai mia senhor, sempr'eu esto temi, cabe suspeitar que ambas puderam ser da autoria de Múnio Fernandes, mas que nalgum momento se produziu uma atribuição errada da segunda a Fernão Figueira de Lemos ${ }^{180}$.

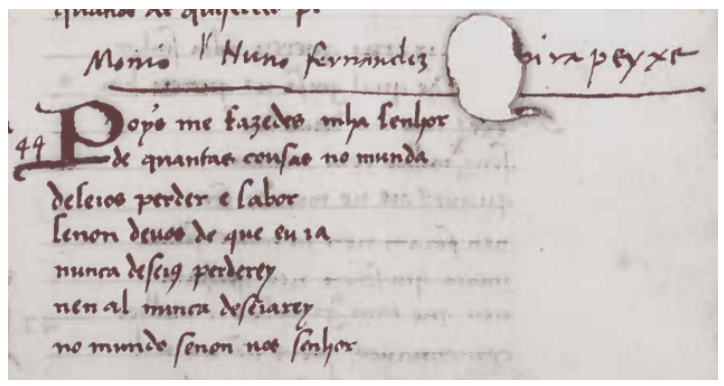

Cancioneiro da Biblioteca Nacional (B, fl. 15rb)

A disposição material da segunda composição atribuída ao de Mirapeixe sugere que se trata de um texto único, mas o invulgar da estrutura métrica e certa descontinuidade discursiva levou a pensar na "junção de versos que originalmente pertenciam a estrofes diferentes da mesma composição ou mesmo a composições diferentes" (Oliveira 1994: 394) ${ }^{181}$. A base para esta última suposição está "nas claras ressonâncias com alguns incipit de outras composições" do quinto verso da composição "quantos oje no mundo son" (p. 395). Precisamente, o incipit que mais se lhe aproxima é aquele com que se abre a cantiga Quantos aqui d'Espanha son de que é autor Pai Soares de Taveirôs - um dos trovadores mais relacionados com Rodrigo Gomes -, em cuja obra foram notados indícios de diálogo poético com o de Mirapeixe (Vieira 2005: 749) ${ }^{182}$.

\footnotetext{
Dizer-vos quer' eu, mia senhor, de qual guisa vos quer' eu ben, e Deus nom me dê [de] vós ben se vos de nulha ren mentir: $[\ldots]$ Quantos oje no mundo son nen foran, nen ja máis seran nunca quiseron nen querrán nen queren gran ben a molher

com'eu vos quer', e non me val contra vós nen esto nen al.
}

\section{Conclusão}

Apesar dos notáveis avanços produzidos, desde finais do século passado, no nosso conhecimento histórico sobre as fases mais recuadas do lirismo medieval, a única referência nominal indubitável a Múnio Fernandes de Mirapeixe permanecia oculta nos ricos fundos da Sé de Lugo. Afortunadamente, o nome dele surgiu numa autêntica joia documental, a $\mathrm{No}$ tícia da casa da Cruz, escrito que revelou uma enorme potencialidade para, partindo dele, recuperar dados essenciais sobre o trovador em questão e ainda sobre a sua estirpe. Eles permitem confirmar, como principal conclusão, a integração do Mirapeixe no elenco dos mais antigos representantes da lírica galego-portuguesa: aqueles cuja atividade poética pode ser situada entre as décadas finais do séc. XII e as duas primeiras do séc. XIII.

179 Esse facto impossibilita explicar, por outra via, as conexões poéticas analisadas, uma vez que não podemos recorrer a um eventual convívio de ambos os autores.

180 Estamos conscientes dos problemas que encerra basear a conjetura em questões estilísticas, levando em consideração a grande homogeneidade do movimento poético.

181 Na reprodução do texto seguimos a decisão adotada por Ferreiro (2018), que considera a existência de duas sequências estróficas e uma fiinda de dois versos; sendo necessário pensar, pelo menos, na perda de uma segunda estrofe. Vejam-se também as edições editoriais de Lopes 2011 e Brea 2019.

182 Veja-se também Souto Cabo 2012: 204-205. 


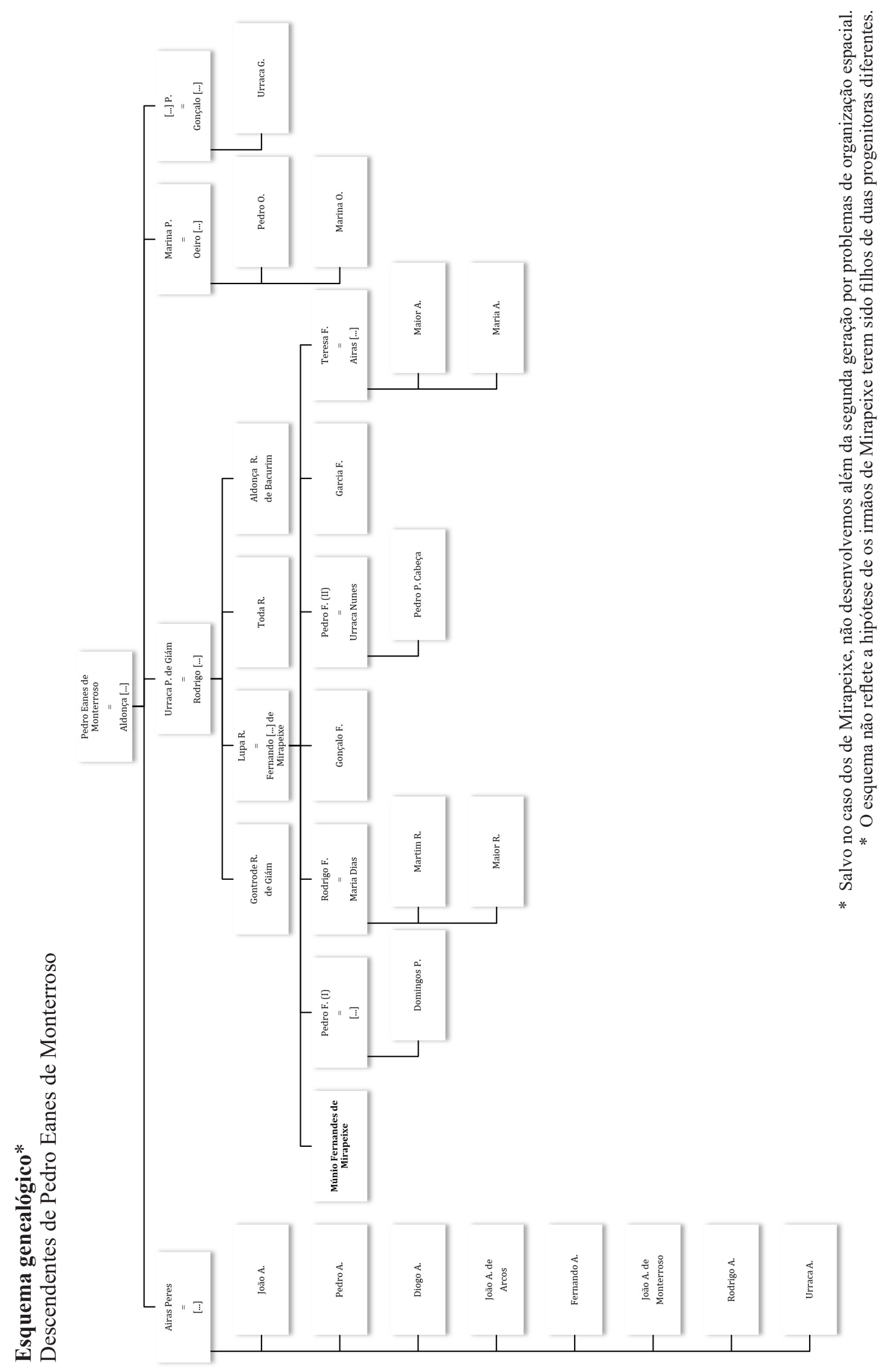




\section{Apêndice documental}

1

1195, janeiro, 27 - Romano, cónego e notário de Lugo.

AHN, Catedral de Lugo, maço 1326A, no 13.

Pedro Oares vende ao bispo de Lugo meia quinta de uma casa em Portomarim que pertenceu a seu avô Pedro Eanes de Monterroso.

Manifestum est scripturam que diem et annum evidenter expressum habuerit et testibus idoneis roboratam fuisse constiterit firmitudinis robur debere per omnia obtinere. Inde est quod ego, Petrus Odoarii, vobis, domno Ruderico Secundo lucensi episcopo, libenti animo nullo cogente vel suadente, facio cartam venditionis medietatis unius quinte $<\ldots>$ case que fuit domni Petri Johannis de Monte Roso, que est in Portumarin, in parte Sancti Nicholai, que casa est in fronte ipsius Pontis Minei, inter casam que fuit Munionis Papin et casam que fuit domni Cristofori. Et habui eam ex sucessione avi mei, prefati Petri Johannis de Monte Roso, et matris mee, Marine Petri, et de ganancia de sorore mea Marina Odoarii. Hanc median quintam tocius prefate case integram vobis, sincera mente et spontanea voluntate, vendo. Et accipio a vobis pro ea CL solidos turonensis monete, precium quod nobis complacuit et de quo apud vos nichil remansit. Amodo, de dominio meo et potestate ablata vestro sit dominio tradita et confirmata, et succesorum vestrorum post vos, meo iure remoto. Si quis vero, quod fieri non credo, contra hoc nostrum factum venerit vel venero, quod calumpniatus fuerit, vobis vel vocem vestram pulsanti duplicatum restituat et hoc scriptum inviolatum permaneat. Factum est era $\mathrm{M}^{\mathrm{a}} \mathrm{CC}^{\mathrm{a}}$.XXX $\mathrm{XX}^{\mathrm{a}}$.III ${ }^{\mathrm{a}}$ et quotum VI kalendas februarii. Tempore regis domni Adefonsi, episcopi lucensis domni Ruderici Secundi, comitis Gomicii, Garsie Ramiri comendatoris, Petri Guiraldi prioris, Fernandi Johannis capellani, Johannis Maheta maiorini in prefata villa de Portumarin. Ego, predictus Petrus Odoarii, roboro et confirmo. Qui presentes fuerunt: Decanus domnus Johannes Arie, testis. Archidiaconus Rudericus, testis. Judex domnus Johannes, testis. Fernandus Oveci, canonicus, testis. Reginaldus, canonicus, testis. Martinus Adefonsi, canonicus, testis. Pelagius Sebastiani, canonicus, testis. Pelagius Odoarii, testis. Petrus Johannis, presbiter canonicus, testis. Johannes Rolan, presbiter canonicus, testis. Pelagius Abbas, presbiter canonicus. Nuno, presbiter canonicus, testis. Rudericus, magister canonicus, testis. Petrus Garsie, diaconus canonicus, testis. Sancius Muniiz, diaconus canonicus, testis. Romanus, lucensis notarius, notuit.

\section{2}

1199, dezembro, 5 - Romano, cónego e notário de Lugo.

AHN, Catedral de lugo, maço 1326B, no 15.

Múnio Fernandes vende a D. Rodrigo, bispo de Lugo, a herdade de Cambra (Campo, conc. Lugo) que recebera de $D^{a}$ Guiomar Rodrigues de Trava com a anuência dos filhos, Rodrigo Dias (dos Cameros), Álvaro Dias e Ínhigo Dias.

Manifestum est scripturam que diem et annum evidenter expressum habuerit et testibus idoneis roboratam fuisse constiterit firmitudinis robur debere per omnia obtinere. Inde est quod ego, Munio Fernandi, miles, bono animo et sana voluntate, vobis, domno Ruderico lucensi episcopo et ecclesie vobis conmisse, facio cartam venditionis tocius hereditatis de Camera cum omni iure suo, quam michi hereditario iure dedit et concessit domna Giumar, pro bono servitio quod sibi feci, concedentibus Ruderico Didaci, et Alvaro Didaci et Enego Didaci filiis suis. Vendo unquam vobis prefato episcopo et Ecclesie Lucensis predictam hereditatem de Camera, que est in Paleares, cum omni iure suo et cum pertinenciis suis omnibus. Sciliced, cum familia sua, cum casis et casalibus, cum terris cultis et incultis, cum montibus et fontibus, pratis et $\mathrm{pa}[\mathrm{s}]$ cuis et cum exitibus suis et cum omnibus illis que ad ipsam spectant hereditatem. Et accipio a vobis pro ea in precio DCCC soldos andegavensis monete. Amodo, faciatis de ea tota vestram voluntatem et sucessores vestri post vos, meo dominio remoto. $\mathrm{Si}$ vero aliquis contra hoc venerit vel venero quod calumpniatus fuerit, vobis duplicatum restituat et hoc scriptum inviolatum permaneat. Factum est era $\mathrm{M}^{\mathrm{a}}$.CC ${ }^{\mathrm{a}} . \mathrm{XXX} \mathrm{X}^{\mathrm{a}}$.VII ${ }^{\mathrm{a}}$ et quotum nonas decembris. Tempore regis domni Adefonsi. Ego, prefatus Munio Fernandi, roboro et confirmo. Qui presentes fuerunt: Rudericus Fernandi, miles, testis. Petrus Veremudi, testis. Mangasoldu, testis. Martinus Johannis, testis. Veremudus Caugu, testis. Petrus Petris, testis. Johannes Petri, testis. Petrus Didaci, testis. Petrus Johannis, testis. Didacus Pelagii, canonicus, testis. Pelagius Sebastiani, canonicus, testis. Martinus Petri, testis. Romanus, lucensis notarius, notuit. 
3

1211, janeiro.

AHN, Ordens Militares, S. Marcos de León, maço 386, n 103.

Testamento de Gontrode Rodrigues, abadessa de Santa Maria de Giám.

Hec est manda quam ego, domna Gontrode Ruderici, abbatissa, facio de rebus meis, sub era $\mathrm{M}^{\mathrm{a}}$.CC $\mathrm{CL}^{\mathrm{a}}$. $\mathrm{L}^{\mathrm{a}}$.IX ${ }^{\mathrm{a}}$ et mense ianuarii. In primis mando quod, si de hac infirmitate decessero, corpus meum in cimiterio Sancte Marie de Luco sepeliatur. Et mando mecum unum casale de quintáá ${ }^{183}$ quod est in Gean, et aliud casale in Villarvassino, ambo populata, et aliud in Palacios, sub ecclesia Sancti Juliani de Receli, depopulatum, et porcionem meam quam habeo in casa de Portumarino; scilicet, medietatem quinte partis quam habui cum sorore mea domna Lupa, que ei dimisi porcionem meam in Berlan et ideo ipsa dimisit mihi porcionem suam quam habebat in domibus de Portumarino, et ius meum quod habeo vel habere debeo in monasterio Sancti Michaelis de Bacorin; similiter ius meum in monasterio Sancte Marie de Insula; similiter ius meum in ecclesia Sancti Petri de Mera. Mando quod domnus Rudericus Fernandi de Mirapisce teneat porcionem meam de domibus de Portumarino, excepta magna domo supradicta, et porcionem meam quam habeo in domibus que sunt in Luco in rua Nova; et annuatim, in vigilia Sancte Marie de februario, det lucensibus canonicis in anniversarium XII soldos quos, si in pace non dederit, tunc canonici recipiant ipsas predictas meas porciones. Monasterio de Jean mando hereditatem laicalem quam in Toeriz habeo. Monasterio de Sancti Salvatoris de Villar de Donas mando ius meum in ecclesia Sancti Jacobi de Linares et meum directum, scilicet quartam medietatis, et quartam sexte partis alteri[u]s medietatis et meam porcionem domus de Palaz de Rei. Domno Ruderico Fernandi de Mirapisce mando casale de Montouto et eidem et fratri eius Gundissalvo Fernandi mando duo casalia in Varazon et vocem meam in Montenigro. Johannes, lucensis decanus, testis; Johannes Ordonii, miles, testis. Petrus Pelagii, presbiter, testis. Martinus Berliadi ${ }^{184}$, testis. Petrus Johannis, testis.

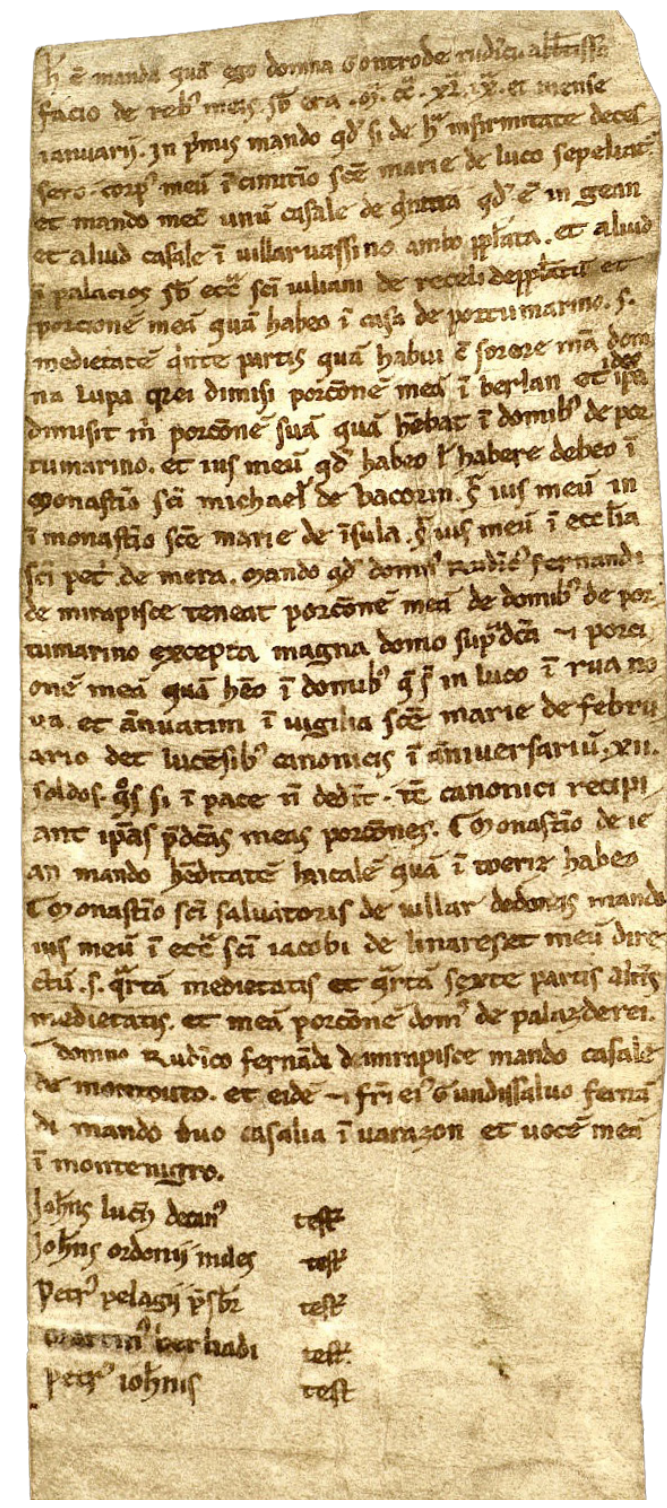

Doc. 3. AHN, Ordens Militares,

S. Marcos de León, maço 386, nº 103

\section{4}

1216, fevereiro, 6 - Pedro Eanes.

AHN, Catedral de Lugo, maço 1326G, no 24.

Rodrigo Fernandes de Mirapeixe recebe de D. Rodrigo, bispo de Lugo, em prestimónio, a vila de "Erosa" (Orosa, conc. Palas de Rei).

Notum sit omnibus ad quos presens scriptura pervenerit quod ego Rudericus lucensis episcopus vobis, Ruderico Fernandi de Mirapisce,

\footnotetext{
183 Consideramos a palavra substantivo, mas não podemos excluir que se trate de uma forma toponímica (talvez hoje desaparecida). As últimas letras foram objeto de emenda.

184 Pode-se tratar de um erro por "Martinus Bernaldi".

185 O númeral "VIII" não faz sentido referido às nonas, portanto, supomos que se trata de um lapso por idos.
} 
do et concedo villam de Erosa in prestimonium in tota vita vestra, ita ut eam bene populetis et excolatis et ex ea sitis semper fidelis vassallus lucensi Episcopo et inde annuatim in festo Sancti Michaelis lucensi Episcopo in pace triginta solidos persolvatis. Ad mortem vero vestram, ipsa villa prenominata cum omni sua populatura et cum omnibus suis fructibus ad ius et dominium lucensis Episcopi revertatur. Et ego supradictus Rudericus Fernandi vobis lucensi [Episcopo] domne Ruderico vestrisque successoribus de prefata villa promitto fidelitatem et me semper redditurum in pace redditum supradictam et prout superius expressistis servaturum. Et si contra hoc fecero, lucensi episcopo centum morabitinos persolvam et predictam villam amittam. Era M $^{\mathrm{a}}$.CC ${ }^{\mathrm{a}}$. LIIII $^{\mathrm{a}}$ et quotum VIII ${ }^{\circ}$ nonas ${ }^{185}$ februarii. Qui presentes fuerunt: Sancius, decanus, testis. Velascus Ruderici, archidiaconus, testis. Archidiaconus Martinus, testis. Archidiaconus Alfonsus, testis. Cantor Lupus, testis. Johannes Froile, canonicus, testis. Johannes Ruderici, canonicus, testis. Garcia Eriz, capellanus, testis. Petrus Johannis notavit.

\section{5}

1225, fevereiro, 18 - Fernando, V. N. de Lourençá.

AHN, Tombo de Loureçá, Códice L.1044, fl. $88 \mathrm{v}$.

Rodrigo Gonçalves de Trava entrega ao mosteiro de Vila Nova de Lourençá o que lhe pertence na diocese de Mondonhedo.

Era M. ${ }^{\mathrm{a} C C}$. ${ }^{\mathrm{a}} \mathrm{LX} .{ }^{\mathrm{a}} \mathrm{III}{ }^{\mathrm{a}}$ et quotum XII ${ }^{\circ}$ kalendas marcii. Notum sit tam presentibus quam futuris quod ego donno Ruderico Gundisalvi volo ire in hostem cum domno rege super terra de mauros et do vel offero vobis, abbate domno G., et omnis conventui Sancti Salvatoris et Sancte Marie Ville Nove de Laurenciana, omnes meas hereditates quas habeo vel habere debeo per episcopatum Mindoniensem, suppignoratas et non suppignoratas. Tota mea porcione concedo vobis ut, in qualicumque loco obiero, habeatis eas vobis et successores vestri, pro remedium anime mee et parentum meorum et propter magnum servicium quod accepi de vestro monasterio ut Deus dimitat mihi. Si quis contra hoc factum meum ad irrumpendum venerit, sit maledictus adeo, et quantum inquietaverit vel inde per vim rapuerit pariat vobis vel voci vestre pulsanti in duplum, et ad vocem regiam mille morabitinos persolvat. Et quod in dubium non sit, ego domno Ruderico hanc cartam manibus meis roboro et confirmo. Qui presentes fuerunt: Rudericus Fernandi de Mirapexe confirmat. Suarius Petri de Veyga confirmat. Raimundus Diaz, miles, confirmat. Johannes Roderici, militem, confirmat. Didacus Menendiz de Begunte confirmat. Et capitulo Ville Nove videntes et audientes. Fernandus qui notuit.

\section{6}

1229, setembro - João Pais (prelado de Rio Torto), V. N. de Lourençá.

AHN, Tombo de Lourençá, Códice L.1044, fls. 36r-v.

Rodrigo Gomes de Trava confirma ao mosteiro de Lourençá a doação da igreja de S. Tomé (conc. Lourençá) feita pelo pai, o conde D. Gomes Gonçalves.

In Dei nomine, amen. Omne quod geritur dignum memoria plus habet, fidei minusque calumnie si firmetur et voce testium et testimonio literarum. Inde est quod ego, domnus Rodericus Gomecii, do et offero Deo et ecclesie Sancti Salvatoris Ville Nove de Laurenzana et vobis, domno Petro Gutterri, eiusdem monasterii abbati, et fratribus ibidem Deo perpetuo servientibus, medietatem ecclesie Sancti Tome de Laurenzana cum totis suis directuris et cum una servicialia que est iuxta ipsam ecclesiam. Quas hereditates iam dederat pater meus comes donnus Gomecius per testamentum et scriptum firmissimum. Et istud facio pro anima mea et in remissione meorum pecaminum et ut particeps $\mathrm{sim}$ in oracionibus vestris. Si quis igitur tam ex parte mea quam extranea contra hanc meam donacionem venire presumpserit, Dei maledictionem incurrat et quod invaserit duplatum vobis restituat et voci regie mille aureos in penam persolvat. Ego, donnus Rodericus Gomecii, hanc cartam quam fieri iussi, propriis manibus roboro et confirmo. Facta carta sub era $\mathrm{M}^{\mathrm{a}}$.CC ${ }^{\mathrm{a}}$.LXVII ${ }^{\mathrm{a}}$, mense septembri. Tempore regis domni Adefonsi, episcopi minduniensis domni Martini. Presentibus: domno Henrico Fernandi. Roderico Fernandi de Mirapisce. Fernando Petri de Bolanio. Munio Fernandi de Rudeyro. Petrus Roderici de Bolanio. Roderico Fernandiz de Aquilar. Petro Roderici de Parrega. Gomecio Veremudi, domni Roderici Gomicii, maiordomo. Petrus Johannis, priore. Pelagio Gundisalvi, monaco. Pelagio Alberti, monaco. Facta fuit ista donacio in monasterio Ville Nove de Laurenzana. Johannis Pelagii, prelatus ecclesie de Riu Torto, scripsit. 


\section{7}

1229, novembro, 30 - Pai Bermudes, notário de Lugo.

AHN, Catedral de Lugo, maço 1327D, nº 10.

D. Rodrigo Gomes e a mulher, Maior Afonso, dão ao bispo de Lugo o que possuem em Lea (conc. Guitiriz) em compensação pelos danos que D. Rodrigo causara no património da igreja de Lugo em Bagueixos (Tirimol, conc. Lugo).

Notum sit omnibus qui presens scriptum inspexerint quod ego, domnus Rudericus Gomez, ad mentem revocans dampna et iniurias quas intuli domno Roderico, bone memorie, quondam lucensi episcopo, et in ipso toti Lucensi Ecclesie in conflicto quem cum eo habui, peccatis meis exigentibus et malorum seductus consilio, in Castro de Bagueixos, in recompensacionem dedecoris ipsi illati Episcopo, do et concedo vobis domno Michaeli, lucensi episcopo, vestreque ecclesie quicquid habeo et habere debeo in Lea, tam in ecclesiis quam in cautis, cum eorum pertinenciis iure hereditario possidendum; vidilicet partem meam et partem sororis mee domne Marie Gomez, quam $\mathrm{ab}$ ea ex donacione ego et uxor mea adquisivimus, et partem comitis domni Gundissalvi, per quam habeo mile solidos. Addo insuper quod quidquid ibi quocumque modo adquisiero sit lucensi Ecclesie. Ita tamen, quod siquid in predictis locis emendum comparaverit, ego et episcopus Lucensis per medium comparemus. Quod si mee in predictis locis aliquid emere vel adquirere quocumque modo contigerit, concedo domne Maiori uxori mee pro parte sua dicte adquisitionis satisfacere per alias hereditates meas. Et quoniam uxor mea Domna Maior, tum ratione dotis, tum obligatione pignoris, tum expredicta donatione, ius, et dominium habere dignoscebatur in predictis locis, donacionem meam ratam, habet et concedit. Si sibi alias non satisfecero in reconpensationem huius donationis, sibi do, et concedo alias hereditates, quas alibi ex donatione adquisivi vel comparavi a sorore mea domna Maria Gomez, ut per eas tantum habeat quantum in predictis locis dignoscitur habuisse. Hinc est quod ego, domna Maior, utilitatem et salutem anime viri mei domni Ruderici Gomez considerans et attendens, prefatam donacionem ratam habeo et confirmo, omni iuri et dominio renuncians, quod in predictis locis habere dignoscebar, totum Lucensi Ecclesiae voluntate spontanea transferendo. Nos vero M. Lucensis Episcopus predictam donationem nomine Lucensis ecclesie acceptantes, quidquid iniurie, sive dampni vos Domnus Rudericus Gomez Lucensi Ecclesie dignoscimini intulisse, remitimus, vobis gratiam facere cupientes predicta loca, quo aduxeritis nomine Lucensis ecclesiae, in prestimonium concedimus possidenda, nobis in signum Dominii, et de vestro beneplacito, retinendo de predictis locis $\mathrm{XX}^{\mathrm{ti}}$ solidos annuatim a vobis in vita vestra nobis pacifice persolvendos. Et quandocumque nos per partes illas transitum facere contigerit, ibi tamquam in possessione propria pausando de nostris sumptibus sustentemus. Sciendum preterea quod ego domnus Rodericus Gomez teneor lucensis burgensibus satiffacere de dampnis qui eis intuli et vobis et ipsis burgensibus, similiter milites qui ibi mecum fuerunt satisfacere non remitto. Facta carta sub era $\mathrm{M}^{\mathrm{a}}$.CC ${ }^{\mathrm{a}}$. $\mathrm{LX}^{\mathrm{a}}$.VII ${ }^{\mathrm{a}}$ et quotum II kalendas decembris. Qui presentes fuerunt: M., archidiaconus. G. Lupi, canonicus. Petrus Arie, canonicus. Johannes Lombardus, canonicus lucensis, testis. Adefonsus Lupi de Le$\operatorname{mos}^{186}$. Petrus Ruderici de Parrega. Rudericus Fernandi de Mirapexe. Johannes Ruderici de Montenigro: milites, testes. Lupus Ruderici de Saavedra. Martinus Froile de Baamundi. Adefonsus Pelagii de Rovera. Rudericus Sebastiani. Arias Petri de Montenigro: milites, testes. Rudericus Martini. Pelagius Menendi. Arias Martini. Fernandus Martini. Martinus Dominici. Petrus Cipriani. Salvador Petri. Adefonsus Petri: burgenses lucenses, testes. Pelagius Veremudi, lucensis notarius, notuit.

\section{8}

1230, fevereiro, 28 - Paio Bermudes, notário de Lugo.

AHN, Catedral de Lugo, maço 1327D, no 22.

Maria Martins vende a Garcia Fernandes, cavaleiro de Mirapeixe, o que possui em Ver (freg. Cela) e no conjunto da freguesia de Cela (conc. Outeiro de Rei).

Rectum est scribi quod non opporteat oblivisci. Unde ego, Maria Martini, vobis, Garsie Fernandi, militi de Mirapexe, libenti animo, nullo cogente vel suadente, facio cartam vendicionis medietatis tocius hereditatis mee quam

186 Em AHN, Cat. de Lugo, 1327D, no 9 aparece como “Adefonsus Petri de Lemos". 
habeo et habere debeo ex parte patris mei, Martini Munionis, in Vaer et in totis terminis eius cum omni voce sua laicali et ecclesiastica, ubicumque eam potueritis, in filigrisia Sancte Marie de Cela, cum omni iure suo, sicut eam solebat tenere pater meus prefatus. Et accipio a vobis pro ea $\mathrm{C}$ solidos monete regis legionensis. Amodo, faciatis de ea totam vestram voluntatem et vox vestra post vos, meo dominio remoto et postetate. Si vero aliquis contra hoc venerit vel venero, quod calumpniatus fuerit, duplicatum vobis restituat et hoc scriptum inviolatum permaneat. Factum est era $\mathrm{M}^{\mathrm{a}}$.CC . LX $^{\mathrm{a}}$.VIII et quotum II kalendas marcii. Tempore regis domni Adefonsi, episcopi lucensis domni Micahelis, tenentis terram ipsam domni Ruderici Gomecii, maiorini eius Oveci Froile. Ego, prefata Maria Martini, roboro et confirmo. Qui presentes fuerunt: Vermudus Gundissalvi, presbiter de Cela, testis. domnus Johannes Johannis de Carvaliali, testis. Petrus Petri Dalpe, testis. Michael Plenus, testis. Petrus Petri, filius Petri Froile zapatarii, testis. Rudericus confrade, testis. Petrus Fernandi, frenarii, testis. Pelagius Veremudi, lucensis notarius, notuit.

\section{9}

1237, dezembro, 31 - Pedro Albano (notário em Nendos e Pruços), Betanços.

ACS, Tombo $C$, fl. 154 r.

Urraca Lopes e o marido, Froila Afonso, vendem a D. Rodrigo Gomes de Trava propriedades na terra de Pruços que pertenceram a Pedro Garcia de Ambroa (primeiro marido de Urraca Lopes).

Ego domna Orraca Lopiz, per bonam pacem et voluntatem, una cum viro meo domno Froilla Alfonsi, pro me, et pro omni voce nostra e pro omnibus filiis et filiabus meis, vobis, domno Roderico Gomez, et uxore vestre, domne Maiori Alfonsi, et voci vestre, facio cartam venditionis et textum scripture perdurabilis de omnibus meus hereditatibus quas habeo et habere debeo ex parte abiorum et parentum meorum et de meis arris, et de meis lucris, et de totis quas ganavi et comparavi cum meo marito Petro Garcia de Ambroa et quas de illo habui tam pro donacionem, quam per arris in tota terra de Prucis [...]. Facta carta apud Betanzis per Petrum Albanum, iuratum notarium. Era $\mathrm{M}^{\mathrm{a}} \cdot \mathrm{CC}^{\mathrm{a}}$. $\mathrm{LXXV}^{\mathrm{a}}$ et quotum II kalendas ianuarii, en tempore regis Fernandus in Castella et Tolleto, Legionis et Gallecia; Trastamar, Rodericus Gomez [...]. Qui presentes fuerunt: Arias Petri de Parrega, testis. Rodericus Sebastiani de
Goios, testis. Fernam Roderici de Santa Maria, testis. Garcia Fernandi de Mirapisce, testis. Didacus Petri, iudex, testis. Fernando Alfonso de Duancos, testis. Fernandus Petri de Andrade, testis. M. de Degio, testis. [M.] Egidii de Asma, testis. Garcia Lopiz, testis. Fernandus Pardo, testis. Fernandus Capellanus, testis. Petrus Albanus, iuratus notarius in Nendos et in Prucis, interfuit et scripsit.

\section{0}

1237, dezembro, 31 - Pedro Albano.

ACS, Tombo $C$, fls. 153 r-v.

Fernando Peres vende a Rodrigo Gomes de Trava o que possui em $S$. Tirso de Ambroa.

In Dei nomine. Ego Fernandus Petri, dictus Pardo, per bona pacem et voluntatem, pro me et pro omni voce mea placuit michi ut facerem vobis, domno Roderico Gomez, et mulieri vestre, domne Maiori Alfonsi, et voci vestre cartam vendicionis sicut et facio de tota mea hereditate quam habeo et habere debeo ex parte abiorum et parentum meorum, tam de ganancia quam de comparacione, in concurrencia Sancti Tirsi de Ambrona. Quantum ego in ipsa villa de concurrencia habeo, totum vobis vendo et concedo pro morabitinos $\mathrm{L}^{\mathrm{a}}[$ [...]. Facta carta era $\mathrm{M}^{\mathrm{a}}$.CC $\mathrm{C}^{\mathrm{a}}$.LXXV ${ }^{\mathrm{a}}$ et quotum II kalendas ianuari, in tempore rege Fernando; Trastamar, Roderico Gomez; sedis vacans a Bernaldo archiepiscopo; archidiaconus Johannes Cresconii. Qui presentes fuerunt: Arias petri de Parrega, testis. Rodericus Sebastiani de Goios. Fernandus Roderici de Sancta Maria, testis. Garsia Fernandi de Mirapisce, testis. Fernandus Alfonsi de Duancos, testis. Fernandus Petri de Andrade, testis. M. Egidii de [Asma], testis. G[arcia] Lopiz, testis. Petrus Albanus iuratus notuit [et] scripsit.

\section{1}

1243, junho, 12 - João Pais, notário da Corunha. ACS, Tombo C, fl. 152r.

Urraca Peres e a irmã, Maria Fernandes de $S a ́$, vendem a D. Rodrigo Gomes aquilo que possuem em $S$. Tirso de Ambroa por oitenta soldos.

In Dei nomine, amen. Ego Orraca Petri simul cum sorore mea Maria Fernandi de Saa, presente et concedente, pro nobis e pro omne voce nostra vobis, domno Roderico Gomecii, et uxori vestre, domne Maiori Alfonsi, omnique voci vestri $[\ldots]$ vendimus et firmiter concedimus, pro LXXX solidos legionensis monete per precium et robur, in tota feligresia 
Sancti Tirsi de Ambroa ad montes et fontes et in omnibus locis ubicumque eam pro nostra voce invenire potueritis, de quibus sumus et fuimus bene paccati [...]. Facta carta vendicionis et confirmacionis $\mathrm{II}^{\mathrm{e}}$ idus iunii, era $M^{\mathrm{a}}$.CC ${ }^{\mathrm{a}}$.LXXXI ${ }^{\mathrm{a}}$. Regnante rege domno Fernando in Castella et in Legione et in Gallecia et in Corduba; compostellano archiepiscopo, Johanne Arie; archidiacono de Nendis, Johannes Cresconi. Testes: domnus Didacus Melendi. P. Gandirio. F. Laurencii. Garsia Fernandi de Mirapixe. Martinus Fernandi. P. Prigicia. P. Petri de Lea. Johannes Petri de Villa Donga: confirmant. Johannes Pelagii, iuratus notarius Crunie, scripsi et confirmo.

\section{2}

1249, agosto, 17 - Fernando Pais, notário de Lugo.

AHN, Catedral de Lugo, maço 1328D, no 26. Maria Dias, mulher que foi de Rodrigo Fernandes de Mirapeixe, oferece à Sé de Lugo a parte que lhe corresponde numa leira em Gamoedo (Mazoi, conc. Lugo).

Sub era $\mathrm{M}^{\mathrm{a}} \cdot \mathrm{CC}^{\mathrm{a}} \cdot \mathrm{LXXXVII}^{\mathrm{a}}$ et quotum $\mathrm{XVI}^{\mathrm{o}}$ kalendas septembris. Notum sit omnibus quod ego, domna Maria Diaz, que fui uxor domni Ruderici Fernandi de Mirapeixe, offero Deo et Ecclesie lucensi et vobis, domno Michaeli eiusdem sedis episcopo, totam partem meam quam ego habeo et habere debeo in quadam larea que est sub aula Sancte Eolalie de Mazoi, in loco Gamoedo vocato, ubi vos modo construitis domos vestras, et presentem cartam inde vobis fieri mando. Qui presentes fuerunt: Dominicus Petri, miles, testis. Lupus Petri, miles, testis. Suerius Ordonii, miles, testis. Fernandus Pelagii, notarius Lucensis, notuit.

\section{3}

1251, setembro, 29 - Fernando Pais, notário de Lugo.

AHN, Catedral de Lugo, maço 1328F, $\mathrm{n}^{\circ} 6$.

Testamento de Teresa Fernandes de Mirapeixe (I).

Sub era $\mathrm{M}^{\mathrm{a}}$.CC ${ }^{\mathrm{a}}$.LXXXIX ${ }^{\mathrm{a}}$ et quotum III $^{\mathrm{o}} \mathrm{ka}-$ lendas octobris. Hoc est testamentum quod ego, Taresia Fernandi de Mirapeixe, infirmitate gravata, tamen sensus mei compos, de rebus meis condo et ordino. In primis, mando domno Michaeli, lucensi episcopo, et eius capitulo $\mathrm{C}$ solidos, unum lectum bonum, unum roncinum bonum, unum pallium, unum ciphum argenteum et unam archam. Mando Dominico
Johannis capellano, operi Beate Marie de Luco, leprosis, et tribus albergariis: XII ${ }^{\mathrm{ci}}$ tercias de pane. Mando etiam Ecclesie Sancte Marie de Luco totum ius patronatus meum quod habeo et habere debeo in ecclesia de Sancto Vincentio de Pias. Et volo et mando et dico quod quicumque, tam ex propinquis meis quam de extraneis, contra hoc testamentum meum venire presumpserit sit maledictus a Deo, Patre et Filio et Spiritu Sancto, et hoc testamentum meum inviolatum semper permaneat. Qui presentes fuerunt: Dominicus Johannis, capellanus domni episcopi, testis. Petrus Fernandi de Candan, testis. Petrus Fernandi de Mirapixe, testis. Urraca Nuni, eius uxor, testis. Petrus Cabeza, eius filius, testis. Dominicus Petri de Mirapexe, testis. Fernandus Pelagii, notarius lucensis, mandato et auctoritate domni Michaelis Lucensis episcopi, transcripsit de originali facto per predictum Petrum Fernandi de Candan.

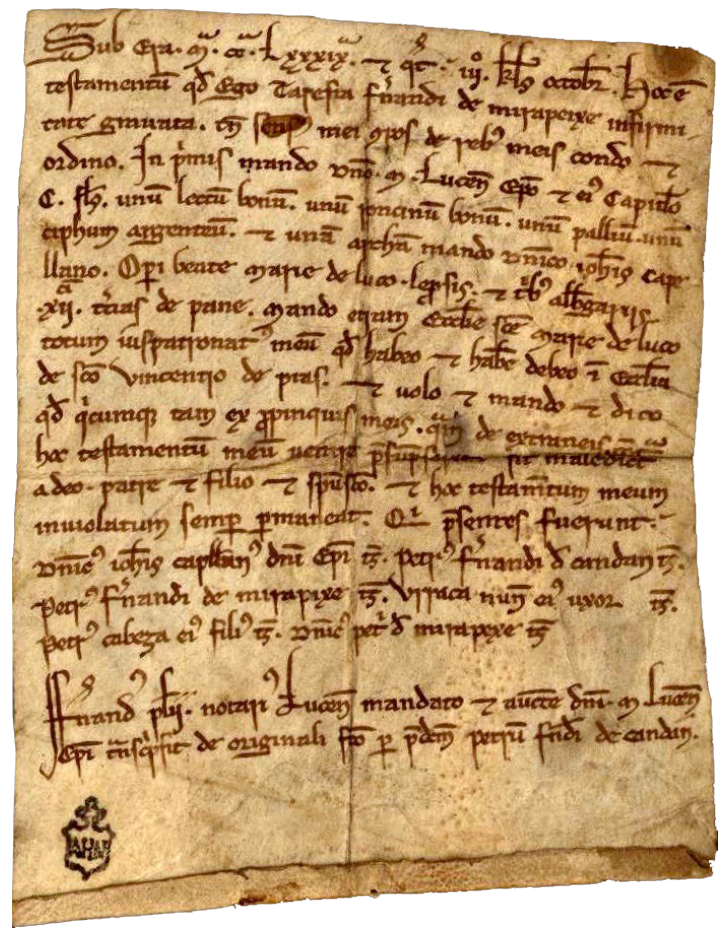

Doc. 13. AHN, Catedral de Lugo, maço 1328F, $n^{\circ} 6$

\section{4}

1251, setembro, 30 - Fernando Pais, notário de Lugo.

AHN, Catedral de Lugo, maço 1328F, $\mathrm{n}^{\circ} 7$.

Testamento de Teresa Fernandes de Mirapeixe (II).

Era $\mathrm{M}^{\mathrm{a}}$.CC ${ }^{\mathrm{a}}$.LXXXIX ${ }^{\mathrm{a}}$ et quotum pridie kalendas octobris. Quoniam ego domna Taresia Fernandi mando corpus meum et animam 
meam ad Sanctam Mariam de Luco cum C solidis, et cum roncino meo ruzo, et cum cipho de argento, et cum lecto meo cum suis pannis, scilicet: una cocedra, una colcha, et unum chumazo, et unum fazeiroo, et duobus lenzois et uno pallio. Et mando capellano episcopi unam archam que sedet in ecclesia de Tidimor. Et ipse capellanus det VIII ${ }^{\text {to }}$ solidos ad ipsam ecclesiam et duas tercias de pane inter hospitales, et malatariam et operam de Sancta Maria, quas debet Johannes Garsie de Pias, quomodo dividit capellanus et Petrus Fernandi. Et mando medam veterem de Mirapeixe ad ecclesiam de Francos et de Gaudioso, per medium, et duos armentios ad ecclesiam de Francos. Mando totam hereditatem quam habeo in ecclesia de Sancto Vincentio de Pias ad ecclesiam de Sancta Maria de Luco. Et hoc mando tali conditione que valeat usque in finem mundi. Et si aliquis hoc mihi contradixerit, sit maledictus et hoc scriptum inviolatum permaneat. Qui presentes fuerunt: Dominicus Johannis, presbiter, testis. Petrus Cabeza, testis. Maria Fernandi, testis. Petrus Fernandi, testis. Urraca Nuni, testis. Guntrode, testis. Fernandus Pelagii, notarius lucensis, transtulit de primo originali.

\section{5}

\subsubsection{8 - Fernando Eanes.}

AHN, Mosteiro de Ferreira de Palhares, maço $1083, \mathrm{n}^{\mathrm{o}} 23$.

João Pais e a mulher, Maria Martins, pactuam com o mosteiro de Ferreira de Palhares o aproveitamento do herdamento de Pedro Cabeça.

Notum sit omnibus ominibus tam presentibus quam futuris quod ego Johannes Pelagii, que moro aa Pena, sobrino de Michael Johannis et uxor mea, Maria Martiz, facio pactum staticum cum abbas et conventu de Sancte Marie de Ferraria do herdamentu de sou frade Pedro Cabeza: que nos tinamos aquil herdamentu de Pedro Cabeza subredictu en tudos nosus dias. E por ém damos partizom en quanto tem Maria Virmuit por aquila voz, en aquila voz en qui eles demandam por sou frade Pedro Cabeza. E eu Johannes Pelagii, iam dictum de susu, octorgo qui ua remda como mandar Michael Johannis e Johan Frade de ipsi lugar. E si Michael Johannis non over, otro ome bono qual puder aver. Facta carta in era $\mathrm{M}^{\mathrm{a}}$.CC $\mathrm{CC}^{\mathrm{a}}$.LX[L] ${ }^{\mathrm{a}} \mathrm{V}^{\mathrm{a}}$ et quotum VI idus novembris. Que presentes fuerunt: Michael Johannis, clerigo de Sancta Marie de Chuli, testis. Johannes Dominici de Nesperaria, testis. Johannes Pascual, testis.
M. Petri. de Marzam, testis. Fernandus Corel, testis. Petrus Stephani, testis. Petrus Petri, testis. Fernandus Johannis que notuit per mandatum abbas et conventu.

\section{6}

1260, maio, 31 - Lugo.

AHN, Catedral de Lugo, maço 1329G, nº 6.

Maior Airas, filha de Teresa Fernandes de Mirapeixe, oferece à Sé de Lugo o direito de patronato que possui na igreja de Santa Eulália de Pena (conc. Begonte).

Sub era $\mathrm{M}^{\mathrm{a}}$.CC ${ }^{\mathrm{a}}$.LXLVIII ${ }^{\mathrm{a}}$ et quotum $\mathrm{II}^{\mathrm{e}} \mathrm{ka}$ lendas iunii. Noverint universi presentem paginam inspecturi quod ego, Maior Arie, que fui filia domne Taresie Fernandi de Mirapexe, offero Deo et Ecclesie de Sancta Maria de Luco et vobis, domno Michael eiusdem lucensis sedis episcopo, totum ius patronatus meum quod habeo et habere debeo in ecclesia de Sancta Eolalia de Penna, statim trasfferens in Lucensem Ecclesiam dominium et possessionem ipsius. Qui presentes fuerunt: Petrus Didaci, canonicus, testis. Menendus Pelagii, presbiter, testis. Petrus Arie, porcionarius, testis. Rudericus Martini, testis. Munio Pelagii, abbas de Ferraria, testis. Fernandus Pelagii, notarius lucensis, notuit.

\section{7}

1264, abril, 30 - Fernando Eanes.

AHN, Mosteiro de Ferreira de Palhares, maço $1090, \mathrm{n}^{\circ} 6$.

Maria Bermudes e outras herdeiras de Pedro Cabeça, frade de Ferreira de Palhares, dividem com o mosteiro o que a ele pertencia na freguesia de Zolhe (conc. Guntim).

Era $\mathrm{M}^{\mathrm{a}} \cdot \mathrm{CCC}^{\mathrm{a}} \cdot \mathrm{II}^{\mathrm{a}}$ et quotum $\mathrm{II}^{\mathrm{e}}$ kalendas may. Conuszuda cosa sea aos que sum e aos que am de viir que eu, fila de Marina Perez, Maria Vermuiz e nós filas da Azenda Perez: Marina Perez, e Sancha Perez, Horraca Perez, Serra Perez, Terexa Perez, in un cum nossos maridos, fazemos plazo e carta cum dom Munio Payt, abbade de Sancta Maria de Ferreira, e cun-no convento de ipsi mismo lugar, damus a eles por quinum de Pedro Cabeza, por quanta herdade avia in a fiigregia de Sancta Maria de Zule, a leyra de Lagoela - dicta do Casal dos Merlos -, et a mea da leyra da Farnal e a castinera de cima do Porto do Barrero, desta parte contra a villa. E nós, abade e convento subredictos, recebemos este quinum por nosso frade Pedro Cabeza, e otorgamos a estes herderos que o al 
que o agam in paz, et nós per aquesto seermos entregos daquel quinum e per mandado de omees boos, que presentes furom: o abade e o convento subredictos, testes. dom Marques, testis. Pedro Sanchit de Nadale, testis. Fernan Johannis qui notuit.

\section{8}

Sem data.

AHN, Mosteiro de Ferreira de Palhares, maço $1096, \mathrm{n}^{\circ} 20$.

AHN, Mosteiro de Ferreira de Palhares, maço $1097, \mathrm{n}^{\mathrm{o}} 10$

Pesquisa testemunhal sobre a titularidade do vilar de Couso (fragmentos)

1. Scilicet, unus clericus presbiter de cauto Sancti Felicis, iuratus, dixit quod vidit semper ad illos homines de Villarino talare et pacere in Causo et nemo eis contrariebat. Et audivit dicere de Hospitale de Pena Godom quod tornabit eum dom Petrus Eanis de sub camino susu, pro quo dicebant que erat hereditas Ferrarie.

2. Scilicet, unum clericum diaconum, fora de cauto Ferrarie, iuratus, dixit quod sedebat in Sancta Eugenia, quod audivit interrogare dompnus Ordonius ad dompnum Ramirum de Pena Godom: si sciebat quando entenzara el comendador dompnus Munio cum dom Petro Eanis. Tunc dompnus Ramirus dixit quod sciebat: quando dom Petrus Eanis volebat ponere hospitalem sub camino, tunc venit el comendador dom Munio et noluit leyxare facere nihil, quod dixit erat suam hereditatem. Et hoc dixit de tempore quod audivit: $\mathrm{L}$ annos.

3. Unus clericus presbiter de cauto de Ferrarie, iuratus, dixit quod audivit dicere, pro veritate, quod vilar de Causo erat Ferrarie et veniebat usque Caminum Sancti Jacobi. Et dixit quod vidit, in dias de dom Ramiro, coler ad Pelagium Faverum madera pro facere domum sub Camino, tunc venerunt herderos de Monte Roso et noluerunt ei lexare ibi domum, quod erat hereditas Ferrarie. Et audivit dicere ad Corderum quod audivit dicere ad patrem suum quod vidit levare ferramentas ad Ferrariam pro quo talarant madeyra in illa hereditate. Hoc dixit quod sciebat de ante annum malum. Et dixit quod stabat presens coram decano dom
Johannes Arie, quod facent domum hospitalis sub Caminum, tunc dixit decanus: "Nolo quare est hereditas Ferrarie".

4. Unus homo de cauto, iuratus, dixit quod vidit quando dixerat ad decanum, dom Johannem Arie, quod facent domum hospitalis sub camino, et ipse noluit, quod dixit que erat hereditas Ferrarie. Et dixit quod audivit dicere, pro veritate, de illo monte quod erat Ferrarie. Et dixit quod vidit pacere capras de hospitalero in illa hereditate. Tunc Dominicus Petri, maiordomus de dom Fernando Muniz, [venit] et levavit eas et pettaverunt ei pro illas $\mathrm{V}$ solidos.

5. Unus clericus presbiter, monachus Ferrarie, iuratus, dixit quod fuit cum abbate dom Johanne pro poblare illum vilarem de Causo et quando fuit ad Cordal, tunc tornavit et dixit: "Poblemus istum Sancti Pelagii quod est plus preto". Et audivit dicere ad dompnum Fernandum Arie, comendatore, quod dixit ad abbatem dom Abril: "Ite poblare ipsos vilares <.?.> de tras-lo monte, ante que nos hic faciatis pesar". Et audivit dicere quod sempre quod ille mons de Causo erat Ferrarie".

6. Unus homo de Cauto, iuratus, dixit quando erat puer pequeno audivit dicere ad Ramirum Muniz, quod morabat in Pena Godom, et dixit ei: "Vide quare tornamus hunc locum et hospitalem huc, pro quo illa hereditas erat condis et Ferrarie". Et iste homo fuit cum abbate dom Abril, et dixit Rodericus Arie, filius de dom Arias Petri, et dixit ad abbatem: "Ista hereditas est vestra, et audivi dicere ad patrem meum et avuolum meum que erat vestra de hospitale ad iusum". Et hoc audivit dicere pro veritate.

\section{9}

Sem data (1235-1265) - Fernando Pais, notário de Lugo.

AHN, Catedral de Lugo, maço 1331H, nº 24.

Inventário dos indivíduos através dos quais a Sé de Lugo obteve a posse de uma casa na Cruz.

Isti sunt quiniones quos habet Lucensis Ecclesia, in duas quintas que fuerunt Arie Petri, in domo que stat in Cruce: primo de decano Johan ${ }^{187}$ Arie, et secundo de Petro Arie, tercio de

187 Para as três ocorrências deste nome, o manuscrito regista apenas a forma abreviada "Jo". Seguindo a tendência romanceadora que observamos no documento para a representação dos antropónimos, utilizamos a forma Johan. 
Didaco Arie, quarto de Johan Arie de Archos, quinto de Fernando Arie de Villanova, sexto de Johan Arie de Monte Roso, septimo de Ruderico Arie. De quinta que fuit de domna Marina Petri, habet Sedes Lucensis mediam; scilicet: unum quinionem de Petro Odoarii et altero de Marina Odoarii. Et quinta integra quam habet de domna Urraca Gunzalvi. Et de altera quinta que fuit de miona domna Urraca de Igian, habet inde quartam de domna Eldoncia de Bacorin, et alteram quartam habet de domna Guntrode, que fuit abbatissa de Igian, et alteram quartam de illis de Mirapixe, scilicet: de Petro Fernandi, et Ruderico Fernandi, et de Monio Fernandi, et de Gunzalvo Fernandi. Et de quarta de quinta que fuit de domna Toda Ruderici, habet inde Sedes unum quinionem, quod dedit Marina Pelagiiz et altero quinione de domna Toda Pelagii. Fernandus Pelagii, notarius lucensis, transcripsit.

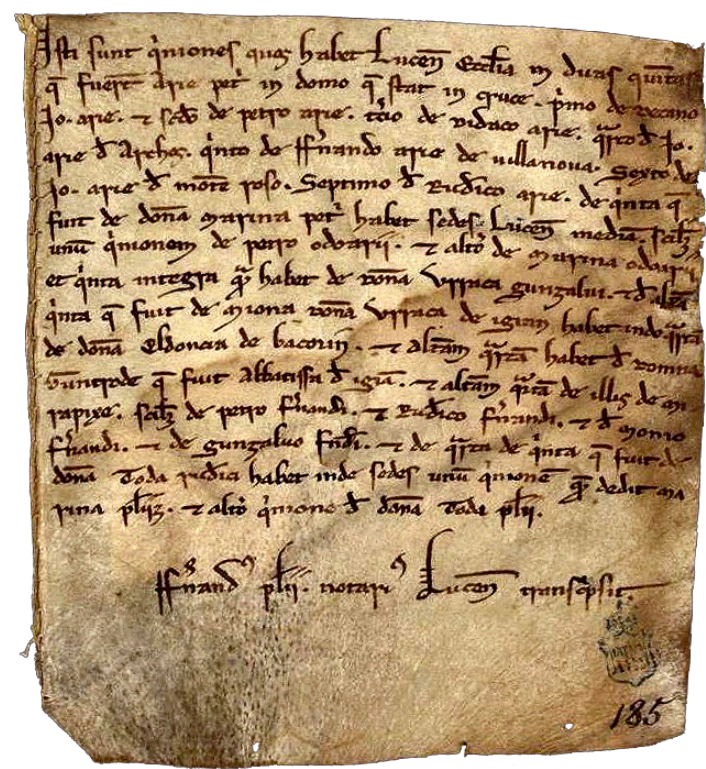

Doc. 19. AHN, Catedral de Lugo, maço $1331 \mathrm{H}, \mathrm{n}^{\circ} 24$

\section{Referências bibliográficas}

Ayala Martínez, Carlos de (1995): Libro de privilegios de la Orden de San Juan de Jerusalén en Castilla y León (siglos XII-XV). Madrid: Editorial Complutense.

Barquero Goñi, Carlos (1999): "La Orden de San Juan en el Camino de Santiago: La bailía de Portomarín (1158-1351)", Cuadernos de Historia Medieval 2, pp. 87-119.

_ (2009): "Relaciones de la Orden de San Juan de Jerusalén con las otras órdenes militares en Castilla y León (siglos XII-XIII)", Norba. Revista de Historia 22, pp. 145-157.

Barton, Simon (1997): The Aristocracy in Twelfth-Century Leon and Castile. Cambridge: Cambridge University Press.

Bermúdez Beloso, Mariña (2017): O espazo do occidente peninsular e a súa organización territorial (ca. 700-ca. 1250). Tese de doutoramento (inédita). Santiago: Universidade de Santiago de Compostela.

Brea, Mercedes (2013): "Lírica trovadoresca y relaciones familiares", em A. Martínez Pérez, C. Alvar e F. J. Flores (eds.), Uno de los buenos del reino. Homenaje al prof. Fernando D. Carmona. San Millán de la Cogolla: Cilengua, pp. 115-127.

(2016): "Otra vuelta a Raimbaut de Vaqueiras y la lírica gallego-portuguesa”, em C. Carta, S. Finci e D. Mancheva (eds.), Antes se agotan la mano y la pluma que su historia. Homenaje a Carlos Alvar. S. Millán de la Cogolla: Cilengua, vol. I, pp. 509-523.

(2019): Base de datos da Lírica Profana Galego-Portuguesa (MedDB). Santiago de Compostela: Centro Ramón Piñeiro para a Investigación en Humanidades, http://www.cirp.gal/meddb [consulta: agosto de 2020].

Cal Pardo, Enrique (2005): Tumbos del archivo de la Catedral de Mondoñedo. Calendarios. Lugo: Deputación Provincial.

Cañizares del Rey, Ventura (2015): Colección diplomática III. Transcripción, edición e índices a cargo de M. Rodríguez Sánchez, O. González Murado, M. Luisa Doval García. Lugo: Publicaciones Diócesis de Lugo.

Cavero Domínguez, Gregoria (2014): "El monasterio medieval, sede de solar nobiliario y refugio de mujeres de la aristocracia”, em J. A. García Cortázar e R. Teja (coords.), Monasterios y nobles en la España del románico. Aguilar de Campoo: Fundación Santa María la Real, pp. 99-135.

Coira Sanjurjo, José María (2012): Algunhas casas fidalgas da Terra Chá e doutros lugares. Ed. de JoséLuis Novo Cazón. Vilalva: Instituto de Estudos Chairegos.

D’Emilio, James (1996): "Los documentos medievales como fuente para el estudio de las parroquias e iglesias gallegas: el distrito de Monte de Meda (Lugo)", Cuadernos de Estudios Gallegos 43, pp. 37-95. - (2008): "The Cathedral Chapter of Lugo in the Twelfth and Thirteenth Centuries: Reforma and Retrenchment", em S. Barton e P. Linehan (eds.), Cross, Crescent and Conversion. Studies on Medieval Spain and Christendom in Memory of Richard Fletcher. Leiden: Brill, pp. 193-226. 
Díaz de Bustamante, José Manuel (2019): Corpus Documentale Latinum Gallaeciae (CODOLGA). Santiago de Composela: Centro Ramón Piñeiro para a Investigación en Humanidades, http://corpus.cirp.es/ codolga [consulta: agosto de 2020].

Fernández de Viana, José Ignacio (1971): La colección diplomática del monasterio de Penamayor. Tese de doutoramento (inédita). Santiago: Universidade de Santiago de Compostela.

Ferreiro, Manuel (dir.) (2018-): Universo Cantigas. Edición crítica da poesía medieval galego-portuguesa. Corunha: Universidade da Coruña, http:// universocantigas.gal [consulta: agosto de 2020].

Fletcher, Richard Alexander (1978): The Episcopate in the Kingdom of Leon in the Twelfth-Century. Oxford: Oxford University Press.

García Conde, Antonio e Amador López Valcárcel (1991): Episcopologio lucense. Lugo: Fundación Caixa Galicia [Separata de Liceo Franciscano, XLIII].

García de Cortázar, José Ángel (2004): "Monasterios hispanos en torno al año mil: función social y observancia regular", em Ante el Milenario del reinado de Sancho el Mayor. Un rey navarro para España y Europa (Actas de la XXX Semana de Estudios Medievales de Estella. 14-18 julio 2003). Pamplona: Gobierno de Navarra, pp. 213-269.

García Tato, Isidro (2004): Las encomiendas gallegas de la Orden Militar de San Juan de Jerusalén. Estudio y edición documental. Tomo I. Época Medieval. Santiago de Compostela: CSIC, Instituto de Estudios Gallegos "Padre Sarmiento".

González, Julio (1960): El reino de Castilla en la época de Alfonso VIII. II Documentos 1145 a 1190. Madrid: CSIC.

González, Déborah e José António Souto Cabo (2018): El arte de trovar de amor. Nuno Eanes y su producción poética. Alessandria: Edizioni dell' Orso [Edición y estudio de Déborah González. Estudio biográfico de José António Souto Cabo].

Jiménez Gómez, Santiago (1987): “O «Memorial de Aniversarios» da Catedral de Lugo como fonte para o estudio da sociedade medieval”, em Jubilatio. Homenaje de la Facultad de Geografia e Historia a los profesores D. Manuel Lucas Álvarez y D. Ángel Rodríguez González. Santiago de Compostela: Universidade de Santiago, vol. I, pp. 161-227.

(1989): Discurso, documento y territorialización en el ámbito de la sociedad lucense del siglo XIII (1180-1302). Tese de doutoramento (inédita). Santiago de Compostela: Universidade de Santiago, 2 vols.

Lamigueiro, Xosé Lois (2016): "Relaciones parientales de los Andrade (I). Los Montenegro", Cátedra 23, pp. 111-129.

Lopes, Graça Videira e Manuel Pedro Ferreira (2011): Cantigas Medievais Galego Portuguesas. Lisboa: Instituto de Estudos Medievais, FCSH/NOVA, http://cantigas.fcsh.unl.pt [consulta: agosto 2020)].

López Ferreiro, Antonio (1902): Historia de la Sagrada A. M. Iglesia de Santiago de Compostela. Vol. V. Santiago de Compostela: Seminario Conciliar Central.

López Sangil, José Luis (2005): A nobreza medieval galega. A familia Froilaz-Traba. Noia: Toxosoutos.

Loscertales de G. de Valdeavellano, Pilar (1976): Tumbos del monasterio de Sobrado de los Monjes (2 vols.). Madrid: Dirección General del Patrimonio Artístico y Cultural / Archivo Histórico Nacional.

Lucas Álvarez, Manuel (1999): El archivo del monasterio de San Martiño de Fóra o Pinario de Santiago de Compostela. Sada: Seminario de Estudios Galegos.

(2004): "El monasterio de San Salvador y San Nicolas de Cis", Estudios Mindonienses 29, pp. 603-728.

Madoz, Pascual (1849): Diccionario geográfico-estadístico-histórico de España y sus posesiones de Ultramar. Vol. XIII. Madrid: Imprenta del Diccionario Geográfico-Estadístico-Histórico de España de Pascual Madoz.

Maia, Clarinda de Azevedo (1984): “«Ona», um arcaísmo galego-português. Breve contributo para o estudo das fórmulas de tratamento na língua medieval galego-portuguesa", Revista de Filología Románica 2, pp. 71-78.

Martín, José Luis (1974): Orígenes de la Orden Militar de Santiago (1170-1195). Barcelona: CSIC.

Mattoso, José e Joseph M. Piel (eds.) (1980): Livros velhos de linhagens. Lisboa: Academia das Ciências de Lisboa.

Michaëlis de Vasconcelos, Carolina (1904): Cancioneiro da Ajuda. Halle: Max Niemeyer [Reimpressão acrescentada de um prefácio de Ivo Castro e do glossário das cantigas (Revista Lusitana XXIII). Vol II. Lisboa: Imprensa Nacional, Casa da Moeda, 1990]. 
Monteagudo, Henrique (2008): Letras primeiras. Oforal de Caldelas, a emerxencia da escrita en galego e os primordios da lírica trobadoresca. Corunha: Fundación Pedro Barrié de la Maza.

(2014): A nobreza miñota e a lírica trobadoresca na Galicia da primeira metade do século XIII. Noia: Toxosoutos,

Mosquera Agrelo, Manuel (2002): “Códice y catedral: el Tumbo Viejo entre los códices del Archivo medieval de la sede lucense", em Iglesia y religiosidad en España. Historia y archivos. Actas de ls V Jorndas de Castilla-La Mancha sobre investiación en archivos (Guadalajara, 8-11 mayo 2001). Guadalajara: Anabad Castilla-La Mancha / Asociación de Amigos del Archivo Histórico Provincial de Guadalajara, vol. 2, pp. 921-939.

Novo Cazón, José Luis (1986): El priorato santiaguista de Vilar de Donas en la Edad Media (1194-1500). Corunha: Fundación "Pedro Barrié de la Maza".

(1993): "Loio, ¿cuna de la Orden Militar de Santiago?, Lvcensia 7, pp. 45-58.

(2008): “Os freires de Vilar de Donas e o Camiño de Santiago", em III e IV Congreso Internacional. O camiño de Santiago. Coñecemento e evolución. Palas de Rei: Concello de Palas de Rei, pp. 103-115

Oliveira, António Resende de (1994): Depois do espectáculo trovadoresco. A estrutura dos cancioneiros peninsulares e as recolhas dos séculos XIII e XIV. Lisboa: Colibri.

Pallares Gaioso, Juan (1700): Argos Divina Sancta Maria de Lugo de los Ojos grandes, fundación y grandezas de su Iglesia, Sanctos naturales, Reliquias y Venerables varones de su ciudad y obispado, Obispos y Arçobispos que en todos los imperios governaron. Santiago: Imprenta de Benito Antonio Fraiz.

Pardo de Guevara y Valdés, Eduardo (1996): Palos, fajas y jaqueles. La fusión de las armerías en Galicia durante los siglos XII al XVI. Lugo: Deputación Provincial.

(2009): "Identidad y memoria genealógica. Una aportación al estudio de la antoponimia medieval gallega", Anuario de Estudios Medievales 39/1, pp. 27-45.

Pérez Rodríguez, Francisco Javier (2019): Los monasterios del reino de Galicia entre 1075 y 1540: de la Reforma Gregoriana a la Observante. Santiago de Compostela: CSIC, Instituto de Estudios Gallegos Padre Sarmiento (Anexo XLII de Cuadernos de Estudios Gallegos), 2 vols.

Portela Silva, María José e José García Oro (1997): La Iglesia y la ciudad de Lugo en la Baja Edad Media. Los señoríos. Las instituciones. Los hombres. Santiago de Compostela: CSIC, Instituto Padre Sarmiento de Estudios Gallegos (Anexo XXIV de Cuadernos de Estudios Gallegos).

Rades y Andrada, Francisco de (1572): Crónica de las tres Órdenes de Santiago, Calatrava y Alcántara. Toledo: Juan de Ayala [Reimpressão em Barcelona: Ediciones “El Albir”, 1980].

Recuero Astray, Manuel; Marta González Vázquez e Paz Romero Portilla (1998): Documentos medievales del Reino de Galicia. Alfonso VII (1116-1157). Santiago de Compostela: Xunta de Galicia.

Recuero Astray, Manuel; María Ángeles Rodríguez Prieto e Paz Romero Portilla (2002): Documentos medievales del Reino de Galicia. Doña Urraca (1095-1126). Santiago de Compostela: Xunta de Galicia.

Rey Caíña, José Ángel (1983): "La abadía de Ferreira de Pallares desde 898 hasta 1300", Cuadernos de Estudios Gallegos 34, pp. 89-115.

(1985): Colección diplomática del monasterio de Ferreira de Pallares. Tese de doutoramento (inédita). Granada: Universidad de Granada, 2 vols.

Romaní Martínez, Miguel (1989): Colección diplomática do mosteiro cisterciense de Sta. Maria de Oseira (Ourense). Santiago de Compostela: Tórculo.

Ron Fernández, Xavier (2015): A fenomenoloxía do don na lírica románica das primeiras xeracións. Tese de doutoramento (inédita). Santiago de Compostela: Universidade de Santiago.

Salazar Acha, Jaime (1984): "Los descendientes del conde Ero Fernandez", El Museo de Pontevedra 43, pp. 67-89.

Souto Cabo, José António (2006): "Pedro de Ambroa e Pedro Garcia de Ambroa", Revista de Literatura Medieval 18, pp. 225-248.

- (2008): Documentos galego-portugueses dos séculos XII-XIII. Monografía 5. Revista Galega de Filoloxía. Corunha: Universidade da Corunha.

- (2012): Os cavaleiros que fizeram as cantigas. Aproximação às origens socioculturis da lírica galego-portuguesa. Niterói: Editora da Universidade Federal Fluminense.

(2016): “En cas da Ifante. Figuras femininas no patrocínio da lírica galego-portuguesa (I)”, em E. Corral Díaz, E. Fidalgo Francisco e P. Lorenzo Gradín (eds.), Cantares de amigos. Estudos en homenaxe a Mercedes Brea. Santiago: Universidade de Santiago de Compostela, pp. 857-870. 
(2018a): "Et de dona Guiomar nascio don Rodrigo Diaz de los Cameros. Figuras femininas no patrocínio da lírica galego-portuguesa (II)", em E. Corral Díaz (ed.), Voces de mujeres en la Edad Media. Berlin/Boston: De Gruyter, pp. 9-32.

(2018b): "Nuno Eanes Cerzeo. Estudio biográfico", em D. González e J. A. Souto Cabo, El arte de trovar de amor. Nuno Eanes y su producción poética. Alessandria: Edizioni dell' Orso.

Souto Cabo, José António e Yara Frateschi Vieira (2003): "Para um novo enquadramento histórico-literário de Airas Fernandes, dito «Carpancho»", Revista de Literatura Medieval 16/1, pp. 221-277.

Tavani, Giuseppe (1990): A poesia lírica galego-portuguesa. Lisboa: Comunicação.

Torres Sevilla-Quiñones de León, Margarita (1999): Linajes nobiliarios en León y Castilla (siglos IX-XIII). Salamanca: Junta de Castilla y León.

Valdés Blanco-Rajoy, Rosario (2016): "El hospital medieval de Pena Godón, una ventana al pasado de un despoblado olvidado en el Camino Francés a Compostela", Madrygal. Revista de Estudios Gallegos 19, pp. 206-216.

Varela Barreiro, Xavier (2004): Corpus informatizado Galego-Portugués Antigo (CGPA). Santiago de Compostela: Instituto da Lingua Galega, http://ilg.usc.es/tmilg [consulta: agosto de 2020].

Varela Cajide, Pablo (2017): "El conde Gómez González de Traba y sus vínculos con el movimiento trovadoresco Gallego-Portugués", Nalgures 13, pp. 315-348.

Vázquez Castro, Julio (1995): "San Salvador de Meroseti (Monseti) y San Pedro de Meixide. Um importante documento artístico", Lucensia 11, pp. 123-140.

Viana y Vieites, José Ignacio (1971): La colección diplomática del monasterio de Santa María de Penamayor. Tese de doutoramento (inédita). Santiago de Compostela: Universidade de Santiago.

(2009): Colección diplomática do Mosteiro de San Pedro de Vilanova de Dozón. Santiago de Compostela: Consello da Cultura Galega.

Vieira, Yara Frateschi (1999): En cas dona Maior. Os trovadores e a corte señorial galega no século XIII. Noia: Laiovento.

(2004), “A via negativa dos trovadores galego-portugueses", em Studi di Filologia romanza offerti a Valeria Bertolucci Pizzoruso. Pisa: Pacini, vol. 1, pp. 639-652.

(2005): "Lírica trovadoresca galego-portuguesa e cultura clerical", em R. Alemany, J. Ll. Martos e J. M. Manzanaro (eds.), Actes del X Congrés Internacional de l'Associació Hispànica de Literatura Medieval. Alacant: Institut Interuniversitari de Filologia Valenciana, vol. 2, pp. 743-752

Viterbo, Joaquim de Santa Rosa (1865): Elucidario das palavras, termos e frases que em Portugal antigamente se usaram. Lisboa: A. J. Fernandes Lopes, 2 vols. 
